\title{
Essays on Women and Historically Disadvantaged Social Groups, and Indian Development Policy
}

Dissertation IN ORDER TO ACQUIRE THE DOCTORAL DEGREE

FROM THE FACULTy OF ECONOMIC SCIENCES

AT The Georg-August-Universität GÖTtingen

\author{
SUBMITTED BY \\ Karan Singh Bagavathinathan \\ BORN IN UDANGUDY, INDIA
}

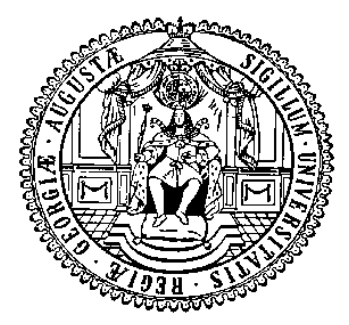

GÖTTINGEN 2019 
Thesis CommitTeE COMPosition:

First supervisor: Prof. Dr. Stephan Klasen

Second supervisor: Ass. Prof. Dr. David Blakeslee

Third supervisor: Prof. Dr. Sebastian Vollmer 


\title{
Essays on Women and Historically Disadvantaged Social Groups, and Indian Development Policy
}

\author{
Karan Singh Bagavathinathan ${ }^{1}$
}

June 5, 2019

\footnotetext{
${ }^{1}$ Email: k.bagavathinathan@stud.uni-goettingen.de. Doctoral student at the University of Göttingen.
} 


\begin{abstract}
The thesis attempts to evaluate three Indian development policies aimed at promoting women and historically disadvantaged social groups. These policies are: job reservation for women in public workfare programs; women's political representation in the Indian state assemblies; political reservation in the state assemblies for historically disadvantaged social groups. The thesis evaluates the three distinct policies in three research papers. The outcomes of the policies could impact various development goals. The first two papers focus on the development policies' effects on children welfare. The third paper focuses on several business outcomes, including those of Scheduled Caste entrepreneurs.

The first paper (co-authored with Ritam Chaurey) examines the impact of the Indian employment guarantee program (MGNREGA - Mahatma Gandhi National Rural Employment Guarantee Act) on the welfare of preschool aged children. Using a difference-in-differences specification stemming from the staggered roll-out of the program between 2006-2007 across districts of India, we find that MGNREGA resulted in a decrease in the number of meals for pre-school and school-going children.

The second paper (co-authored with Francesco Burchi) has two main objectives: (1) to analyze whether the gender of politicians in India influences the educational attainments of the residents of the districts in which they were elected; (2) to test whether politicians are more sensitive to the needs of people of the same gender. Our results show that a 10 percentage increase in women's political representation produces a 6 percentage increase in the probability that children will complete primary school. We then found genderdifferentiated results: that women's political representation affects the education of girls significantly more than that of boys.

The third paper examines the existence of preference in the constituency works of political leaders elected through the Scheduled Castes (SC) electoral quotas. The paper examines the possible business outcomes in the private non-agricultural sectors that directly affect the welfare of the Scheduled Castes as well as other castes. These include: entrepreneurship; entrepreneurs' access to public utilities; entrepreneurs' dependence on family labour sectoral mobility; employment of SC in other caste enterprises; SC entrepreneurs' ability to hire labor from other castes and political patronage. It finds that constituency works of SC leaders do not promote inclusion of SC members in the private sector businesses nor do they affect the overall business outcomes of the other castes. However, this study finds that SC leaders are involved in patronage in the rent-seeking sectors.
\end{abstract}




\begin{abstract}
German

Die folgende These evaluiert drei indische Entwicklungspolitiken, dessen Ziel die Förderung von Frauen und historisch benachteiligten sozialen Gruppen ist. Diese drei Konzepte sind: der Vorbehalt für Frauen in öffentlichen Arbeitsprogrammen; politische Repräsentierung von Frauen in den indischen Staatsversammlungen; politischer Vorbehalt in den Landesversammlungen gegenüber historisch benachteiligten Gesellschaftsgruppen. Die Dissertation bewertet die drei verschiedenen Richtlinien in drei Forschungsarbeiten. Die Ergebnisse der politischen Maßnahmen könnten sich auf verschiedene Entwicklungsziele auswirken. Die ersten beiden Studien befassen sich mit den Auswirkungen der Entwicklungspolitik auf das Wohlergehen der Kinder. Das dritte Papier konzentriert sich auf verschiedene Geschäftsergebnisse, einschließlich der Ergebnisse von Scheduled Castes (SC).
\end{abstract}

Die erste Studie (gemeinsam mit Ritam Chaurey verfasst) untersucht die Auswirkungen des indischen Beschäftigungsgarantieprogramms (MGNREGA - Mahatma Gandhi National Rural Employment Guarantee Act) auf das Wohlergehen von Kindern im Vorschulalter. Anhand einer Differenz-zu-Differenz-Spezifikation, die sich aus der gestaffelten Einführung des Programms zwischen 2006 und 2007 in verschiedenen Distrikten Indiens ergibt, stellen wir fest, dass MGNREGA zu einer Verringerung der Anzahl der Mahlzeiten für Vorund Schulkinder geführt hat.

Die zweite Studie (gemeinsam mit Francesco Burchi verfasst) verfolgt zwei Hauptziele: (1) zu analysieren, ob das Geschlecht der Politiker in Indien das Bildungsniveau der Bewohner der Bezirke beeinflusst, in denen sie gewählt wurden; (2) zu testen, ob Politiker sensibler für die Bedürfnisse von Menschen gleichen Geschlechts sind. Unsere Ergebnisse zeigen, dass eine 10-prozentige Zunahme der politischen Repräsentation von Frauen eine 6-prozentige Erhöhung der Wahrscheinlichkeit zur Folge hat, dass Kinder die Grundschule abschließen. Folglich fanden wir geschlechtsspezifische Ergebnisse: die politische Handlungsfreiheit von Frauen beeinflusst die Bildung von Mädchen stärker, als die von Jungen.

Die dritte Studie untersucht die Existenz von Bevorzugung bei nichtlegislativen Aktionen von politischen Führungspersonen, die durch die Wahlquoten der Scheduled Castes (SC) gewählt wurden. Die Studie untersucht die möglichen Geschäftsergebnisse im privaten nichtlandwirtschaftlichen Sektor, die sich direkt auf den Wohlstand der Scheduled Castes und anderer Kasten auswirken. Dazu gehören: die Geschäftsführung; der Zugang von Unternehmern zu öffentlichen Versorgungseinrichtungen; die Abhängigkeit der Unternehmer von der wirtschaftsfachlichen Mobilität der Familienarbeitskräfte; Beschäftigung von SC in Unternehmen anderer Kasten; die Fähigkeit von SC-Unternehmern, Arbeitskräfte von anderen Kasten einzustellen und politische Schirmherrschaft. Die Analyse zeigt, dass nichtlegislative Handlungen der SC-Führungskräfte weder die Einbeziehung von SC-Mitgliedern in die Unternehmen des privaten Sektors fördern, noch die allgemeinen Geschäftsergebnisse der anderen Kasten beeinflussen. Die Studie stellt jedoch fest, dass die führenden Politiker des SC an der politischen Schirmherrschaft in den rentenorientierten Sektoren beteiligt sind. 


\section{Acknowledgements}

First, I would like to express my sincere gratitude to my advisor Prof. Stephen Klasen for his patience, motivation, and immense knowledge. Prof. Klasen was always available and provided continuous support during my PhD. I cannot imagine having a better advisor and mentor. I further thank my subsidiary supervisors Prof. David Blakeslee, and Prof. Sebastian Vollmer, for their helpful and motivating comments and agreeing to be on my committee.

I would also like to thank my colleagues from two institutions. From the Center for Development Research (ZEF), I would like to thank Prof. Joachim von Braun, Prof. Guido Lüchters, Dr. Benjamin Schraven, Dr. Günther Manske and Mrs. Maike Retat-Amin. From the German Development Institute (GDI), I would like to thank Dr. Tilman Altenburg, Dr. Markus Loewe, and Dr. Francesco Burchi, who provided me an opportunity to join their team as a researcher, access to their research facilities, and for their insightful comments and encouragement. Without their precious support, it would not have been possible to conduct this research.

I would like to thank several of my friends and batchmates from the Bonn International Graduate School

for Development Research (BIGS-DR) at ZEF. I would also like to thank all of my colleagues from the Development Economics Department at the University of Göttingen for their help and support. Thanks to Anna Gyorgy for proofreading.

My sincere thanks to Prof. David Blakeslee and Prof. Ritam Chaurey for their guidance, research collaboration, and the many discussions during my PhD which I greatly benefited from.

I would like to thank my family and friends for their support and understanding while writing this thesis and last but not least my beloved. 


\section{Contents}

$\begin{array}{ll}\text { Contents } & 2\end{array}$

1 Introduction $\quad 7$

2 Rural Employment Guarantee Scheme and Child Nutrition: Evidence from India 13

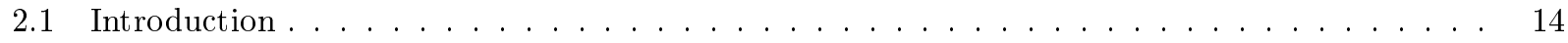

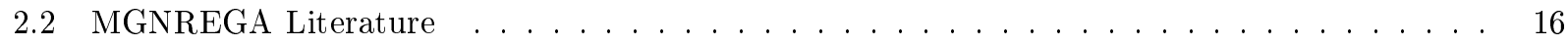

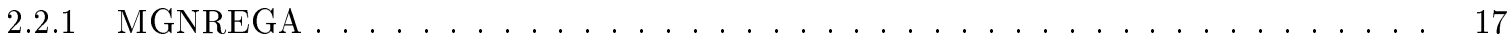

2.3 Empirical Strategy and Data $\ldots \ldots \ldots \ldots \ldots \ldots \ldots$

$2.3 .1 \quad$ Empirical Strategy . . . . . . . . . . . . . . . . . . . . . . 19

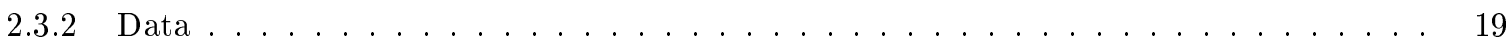

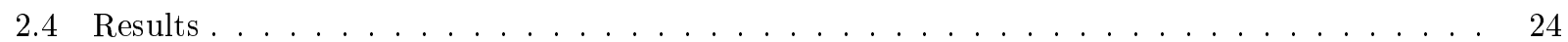

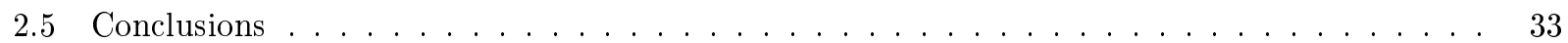

3 Women's political representation and educational attainments: A district-level analysis in India $\quad 34$

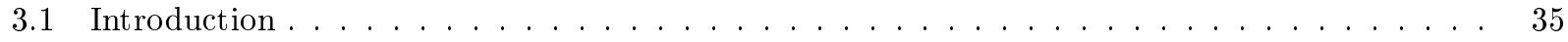

3.2 Women's Representation in Politics, Policy-making and Development Outcomes . . . . . . . 37

3.2.1 Women's political representation and policy-making $\ldots \ldots \ldots \ldots \ldots$

3.2 .2 Development outputs and outcomes . . . . . . . . . . . . . . . . . 39

3.3 The Political Economy of Education $\ldots \ldots \ldots \ldots \ldots$ 
3.4 Data and Methods . . . . . . . . . . . . . . . . . . . . . . 44

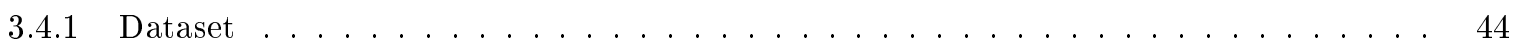

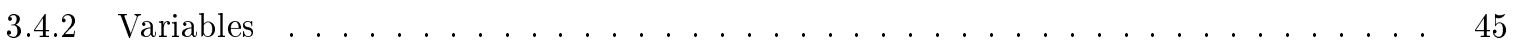

3.4 .3 Estimation strategy $\ldots \ldots \ldots \ldots \ldots \ldots \ldots \ldots \ldots \ldots$

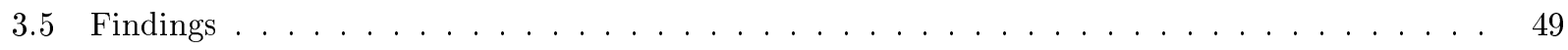

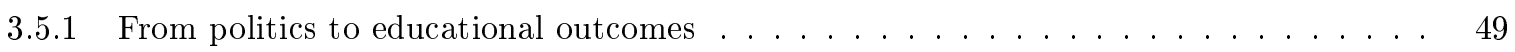

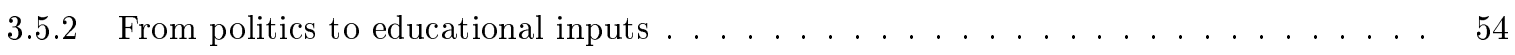

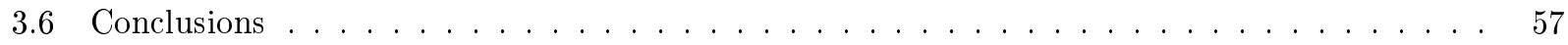

4 Political Reservation for Scheduled Castes and Business Exclusion: Examining Political Quotas' Effects on Private Sector Entrepreneurship,1990 to $2007 \quad 59$

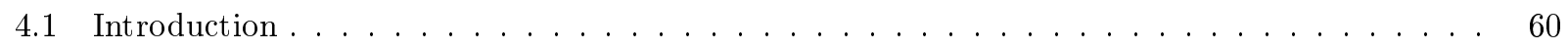

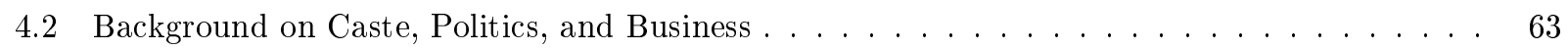

4.3 Empirical Design and Data $\ldots \ldots \ldots \ldots \ldots$

$4.3 .1 \quad$ Empirical Design . . . . . . . . . . . . . . . . . . 66

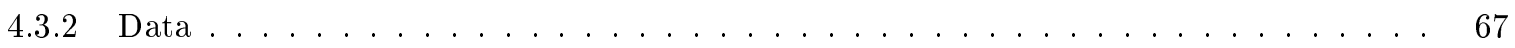

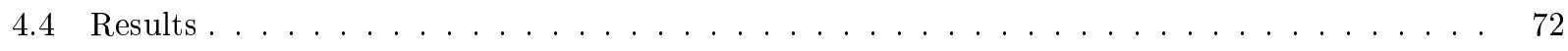

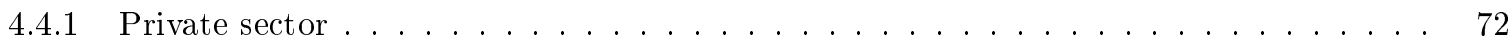

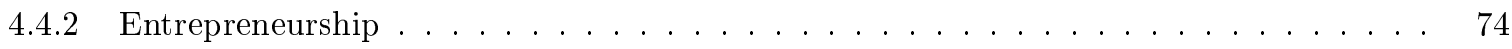

4.4.3 Access to facilities and government support $\ldots \ldots \ldots \ldots \ldots$

4.4 .4 Family workers $\ldots \ldots \ldots \ldots \ldots \ldots \ldots \ldots \ldots \ldots$

4.4.5 Business presence in traditional exploitative sectors . . . . . . . . . . . . . . 79

4.4 .6 Business sector and patronage $\ldots \ldots \ldots \ldots \ldots \ldots \ldots$

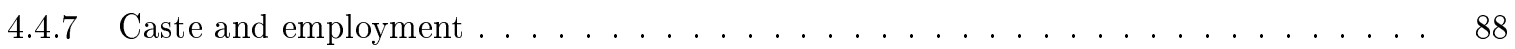

4.4 .8 Intra-village effect $\ldots \ldots \ldots \ldots \ldots \ldots \ldots \ldots$

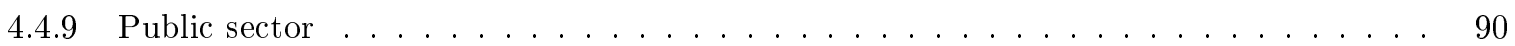

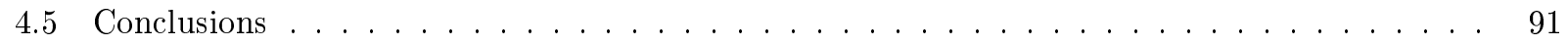


Bibliography 


\section{List of Figures}

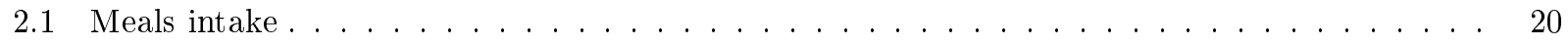

2.2 Estimated coefficient plots for number of meals for different age groups $\ldots \ldots \ldots \ldots$

3.1 Trends in people's probability to complete primary education $\ldots \ldots \ldots \ldots \ldots$ 


\section{List of Tables}

2.1 Pre-program Summary Statistics for Phase 1 and Phase 2 Districts (2004) . . . . . . . . 22

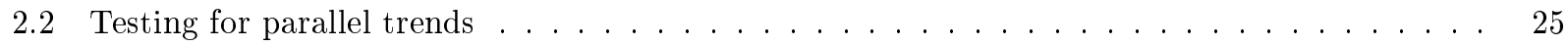

2.3 MGNREGA impact on the meals intake of rural children $\ldots \ldots \ldots \ldots \ldots$

2.5 Households' landholding size: Impact on children of different age groups $\ldots \ldots \ldots$. . . . . 28

2.7 Impact on households during dry and rainy season $\ldots \ldots \ldots \ldots \ldots$

2.8 Impact on quality of food (food diversification) of households $\ldots \ldots \ldots \ldots$

2.9 Impact on the meals intake of rural children: household size and women in the family _ . . . 31

2.10 Impact on children from urban households . . . . . . . . . . . . . . . . . . . 32

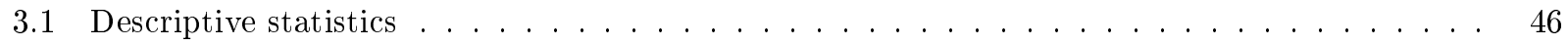

3.2 Effect of women's political representation on primary education completion $\ldots \ldots \ldots$

$3.3 \mathrm{a}$ Tests for the validity of the instrumental variables $\ldots \ldots \ldots \ldots \ldots$

3.3b First stage of the instrumental variable estimates (Table 3.2 column $(2)$ ) . . . . . . . . 51

3.4 Effect of women's political representation on primary education completion: disaggregated

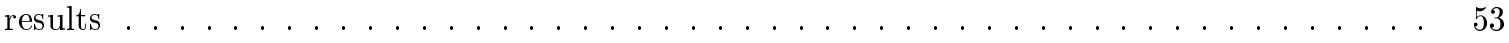

3.5 Effect of women's political representation on educational infrastructures . . . . . . . . . 54

3.6 Effect of women's political representation on Mid Day Meal scheme coverage . . . . . . . 55

4.1 Summary Statistics . . . . . . . . . . . . . . . . . . . . . 69

4.2 Effect of SC reservation on the private sector, SCs participation and overall economic growth 73

4.3 Effect of SC reservation on entrepreneurship of SC enterprises $\ldots \ldots \ldots \ldots \ldots \ldots$ 
4.4 Effect of SC reservation on access to facilities and government support of SC enterprises . . . 77

4.5 Effect of SC reservation on family labor . . . . . . . . . . . . . . . 78

4.6 Effect of SC reservation on traditional exploitative sector(Number of firms . . . . . . . . 79

4.7 Effect of SC reservation on across business sector $(\mathrm{SC}$ firms $) .. . . . . . . . .81$

4.8 Effect of SC reservation on across business sector (employment in SC firms) . . . . . . 83

4.9 Effect of SC reservation on across business sector (non-SC firms) . . . . . . . . . . 85

4.10 Effect of SC reservation on across business sector (employment in non-SC firms) . . . . . 87

4.11 Effect of SC reservation on firms' hiring patterns . . . . . . . . . . . . . . . 88

4.12 Intra-village effect of SC reservation on the private sector, SCs participation and overall economic growth . . . . . . . . . . . . . . . . . . . . . 89

4.13 Effect of SC reservation on the public sector . . . . . . . . . . . . . 90 


\section{Chapter 1}

\section{Introduction}

This thesis attempts to evaluate three Indian development policies aimed at promoting women and historically disadvantaged social groups. These policies are: job reservation for women in public workfare programs, women's political representation within the Indian state assemblies, and political reservation in the state assemblies for historically disadvantaged social groups. The thesis evaluates these distinct policies in three research papers. All three papers are chiefly connected in the field of development economics and share three characteristics; a focus on socially weaker groups - women and lower castes, a robust empirical approach, and all explore important policy implications. Each paper is discussed below along with the main motivation, arguments, and implications.

\section{Essay 1: Rural Employment Guarantee Scheme and Child Nutrition: Evidence from India}

Women are the principle development agents for their infants and children. The development goals related to child welfare depend on the status of women in society (UNICEF, 2006; Kabeer, 2008). Women's allocation of time can increase the welfare of children via two channels: the income from paid work, and the time spent directly in the household with children or on other domestic activities. Women's time allotment on household activities such as meal preparation, breastfeeding, and seeking preventive and curative medical care is vital for infants and children's health Hoffman (1989).

Without government intervention, women have less opportunities to contribute via the income channel. Rural women in developing countries encounter several barriers when trying to participate in paid employment outside the household. The most common are: lack of control 
over assets, low skills or education levels, gender inequality in domestic duties, and stereotyping of women's capabilities (Ashrafi, 2009; Vigneri and Holmes, 2009; Luci et al., 2012; Hambly and Sarapura, 2009). Therefore, developing countries are increasingly intervening in their labour market in order to increase the number of women in the labour force.

For a long history, India has been among one of the developing countries that has excluded women in mainstream economic activities. The Indian government has committed to erase the historic barriers that exclude women. Recently, this has been illustrated in the world's largest public works program, the Mahatma Gandhi National Rural Employment Guarantee Act (MGNREGA). Through this program, one third of total jobs are reserved for women. The program also takes into account women's contribution to their children via domestic duties. Therefore, the MGNREGA program promises to provide adequate childcare services for their women workers.

This essay (co-authored with Ritam Chaurey) critically examines the impact of MGNREGA on children's welfare via time-intensive inputs. Does the women's participation in the programme affect the time-intensive input toward children? The phased rollout of the program allows us to conduct a difference-in-differences estimation to shed light on the question. We use the number of meals eaten by children as a proxy for time allocated by the mother for child care. We find that the number of meals for preschool and school-aged children decreased by 2.3 percent and 3.0 percent, respectively.

Several studies provided evidence of positive impacts on children from the income generated by participation in the programme (Afridi et al., 2012; Islam and Sivasankaran, 2014; Bose, 2017; Maity, 2015; Shah and Steinberg, 2015). However, relatively less attention has been given to the time effect (substitution effect) of the programme. Chari et al. (2019) are the first to examine the effect of MGNREGA on women's time allotment towards childcare. The study finds that women participating in the public works programme reduced prenatal care and breastfeeding. Our study complements this paper by focusing on the time effect of the programme. Our study suggests that adequate public investment in childcare services at the workplace may alleviate the potential tradeoffs between mothers earning additional income and child welfare. 


\section{Essay 2: Women's political representation and educational attainments: A district-level analysis in India}

During the past two decades, a growing body of literature has investigated the effects of women's political representation on a range of economic, political, and social indicators. In the literature on political economy, the 'citizen-candidate model' views the identity of politicians as being one of the fundamental determinants of investment choices (Osborne and Slivinski, 1996). Building on this model, scholars have investigated the specific role played by a politician's gender in policy-making: men and women are assumed to have different preferences, and this is taken as the reason why they make different choices once they obtain political representation. While most of the existing literature focuses on the lowest administrative level, i.e the Gram panchayat or on the states, our analysis looks at the relationship within Indian districts. District politics have not been examined in great detail thus far. The fact that the Indian parliament is currently debating the possibility of reserving a proportion of seats in state assemblies for women is another important reason for focusing on India.

This essay (co-authored with Francesco Burchi) tries to answer three questions. The first one is: Does women's political representation have a positive effect on primary education completion rates? Our aim is to test if women prioritise education and try to divert more resources to this sector. If so, this should be reflected by higher school completion rates. As of this publication, there has been little research exploring this topic To the best of our knowledge, only one paper (Clots-Figueras, 2012) has studied this relationship in India. Clots-Figueras (2012) studies the period between 1970 and 1992. In the late 1990s, many other state governments allocated discretionary funds to MLAs, known as the MLA Local Area Development Scheme Fund (MLALADS). This fund has given space to politicians to execute preferred polices at their constituency. Our study explores the post-political reform period and covers the years 1970-2002.

The two remaining research questions are: a) Do women's political representation affect girls' probability of attaining primary education more than boys'? (This verifies whether female politicians prioritise the education of girls over boys) and b) What are the possible channels through which women's political representation affects educational achievements? Given data constraints, we investigated only a few possible channels, such as the availability of schools - examined in previous studies - and the coverage of the Mid-Day Meal (MDM) scheme, which has not been explored in the literature. 
Our study follows the identification strategy of Clots-Figueras (2012). In order to overcome a major 'omitted variables' bias - due to the fact that more progressive districts are more likely to have more women in political bodies and to invest more in education - our econometric strategy is based on an instrumental variable (IV) approach. Thus, the proportion of district seats won by women was instrumented by the proportion of district seats won by women in close male-female contests, i.e. in elections in which there was a narrow gap between the winner and the runner-up.

Our findings show that a 10\% increase in women's political representation at district level can produce a rise of nearly $6 \%$ in the likelihood of an individual completing the full cycle of primary education. The study of Clots-Figueras (2012), from which we took the identification strategy, focused only on the importance of women's political representation in urban areas. A disaggregated analysis reveals that women's political representation raises the educational achievements of girls significantly more than that of boys. This is a completely novel result, as this aspect had never been examined in previous works.

Finally, we investigated two possible macro-channels through which women's political representation might affect educational outcomes, specifically, the presence of school buildings and the coverage of the MDM scheme Our results show that the first channel does not help to explain the relationship. In contrast, we detect a positive, though insignificant, effect of women's political representation on the MDM coverage and, above all, some positive and significant evidence for the sample of girls. This suggests that female politicians may be particularly interested in girls' education.

The research findings are complementing two broad areas of research. First, it is contributing to the research from (Binswanger-Mkhize et al., 2012; Clots-Figueras, 2012) by providing evidence of women political leaders commitment to improve the educational outcomes. Second it is contributing to the citizen-candidate model (Besley and Coate, 1997; Osborne and Slivinski, 1996) literature, which argues that political leaders will simply not comply with the wishes of the median voter; therefore, this model acknowledges that the identity of political leaders affects policymaking. Gender is regarded as a fundamental component of a leader's identity. Thus, female leaders will make policies that favour women and that focus on what is important to women. 


\section{Essay 3: Political Reservation for Scheduled Castes and Business Exclusion: Examining Political Quo- tas' Effects on Private Sector Entrepreneurship,1990 to 2007}

In the modern Indian economy, exclusion of Scheduled Castes (SC) in the private, nonagriculture sector is a sign of failure in addressing caste discrimination. In 1991, India initiated several reforms to transform its national economy to an open one with a greater reliance on market forces (Ahluwalia, 2002). As a result, private non-agricultural sectors emerged as an engine of Indian economic growth. On the development aspects, critiques were raised by several studies (Damodaran, 2008; Deshpande and Sharma, 2016; Iyer et al., 2013; Jodhka, 2010; Thorat and Sadana, 2009; Varshney, 2007, 2012) which stated that the benefits of rapid economic growth from reforms in 1991 had not been shared equally amongst the different sections of society. The SC, the lower caste social group, are especially underrepresented in the ownership of private non-agricultural enterprises (Iyer et al., 2013).

SC politicians could lead as an agent of change in eliminating caste discrimination. The Indian constitution guarantees political representation of SCs in three spheres of government: central, state, and local bodies. This mandated political representation in governments is expected to bring policies in favour of their castes. Theoretical predictions are ambiguous about the preferences of politicians from underrepresented ethnic quotas. Traditional theoretical models (Downs, 1957; Arrow, 1951; Mayhew, 1974; Fenno and Fenno Jr, 1978; Kingdon, 1989; Cox and McCubbins, 2005) assume that politicians are likely to be vote-seeking or be interested in holding office in future elections as well. High political competition does not allow SC politicians to favour their castes and SC politicians are more likely to follow the command of parties' high command. An alternate view, the citizen-candidate model (Osborne and Slivinski, 1996; Besley et al., 2004; Horowitz, 2001), predicts that politicians are assumed to act in favour of their ethnic group.

Growing literature has examined the preference of Indian politicians (Lehne et al., 2018; Jensenius, 2015; Asher and Novosad, 2017). These studies focus on the preference of members of legislative assemblies in their constituency. The empirical expectations of the literature are that because politicians hold public office for their private return and to serve their patrons, their actions negatively affect the welfare of other castes and negatively affect the efficacy of the political system as they favour towards their castes to reduce the discrimination. 
This paper contributes to the literature by posing the above expectations to the SC politicians' on the private sector outcomes in their constituency. Private sector outcomes are closely relevant to SC politicians as they can prove their political dedication by executing actions to eradicate ongoing discrimination against SCs in the private sector or they can use the rent-seeking sectors in the private businesses as a mode to serve patrons.

This essay answers three research questions: 1) Do SC politicians affect the overall business environment? 2) Do SC politicians favour their castes in private sector business outcomes? and 3) Do SC politicians hold public offices for the private gain?

The findings of the paper show that SC leaders preferences do not promote inclusion of $\mathrm{SC}$ members in the private sector businesses nor do they affect the overall business outcomes of the other castes. However, this study finds that SC leaders are involved in patronage in the rent-seeking sectors. The finding of the research contributes to two research domains: 1) This study's findings support the research of(Jeffrey, 2002; Wilkinson, 2006; Schneider, 2014) through evidence on clientelism and vote buying practices in India 2) This essay supports the Traditional theoretical models (Downs, 1957; Arrow, 1951; Mayhew, 1974; Fenno and Fenno Jr, 1978; Kingdon, 1989; Cox and McCubbins, 2005), which assume that politicians are likely to be vote-seeking or be interested in holding office in future elections as well. 


\title{
Chapter 2
}

\section{Rural Employment Guarantee Scheme and Child Nutrition: Evidence from India $^{1}$}

\begin{abstract}
This paper examines the impact of the Indian employment guarantee program (MGNREGA - Mahatma Gandhi National Rural Employment Guarantee Act) on the welfare of preschool and school-going children. It has been ranked as the world's most extensive public employment program for unskilled workers, with 278 million workers participating in 2016. The program provides gender neutral wages and assurance for childcare at MGNREGA work sites.

This paper attempts to examine the impact of MGNREGA on the food consumption of children (both preschool and school-going) using nationally representative data from the National Sample Surveys between 1999-2007. Using a difference-in-differences specification stemming from the staggered roll-out of the program between 2006-07 across districts of India, we find that MGNREGA resulted in a decrease in the number of meals for preschool and school-going children. The negative effects on the number of meals are partially attenuated in larger households.
\end{abstract}

Key words: Women employment, children nutrition. JEL code: J20, J 23, I10

\footnotetext{
${ }^{1}$ The chapter is based on joint work with Ritam Chaurey. The paper was presented at the development economics seminar, University of Göttingen. We thank all the participants of the seminar for their valuable comments. We thank Prof. Klasen for providing detailed comments in shaping the paper. The usual disclaimer applies
} 


\section{$2.1 \quad$ Introduction}

Rural women in developing countries face several barriers in participating in paid employment outside the household. The most common are lack of control over assets, low skills or education levels, gender inequality in domestic duties and stereotyping of womens' capabilities (Ashrafi, 2009; Vigneri and Holmes, 2009; Luci et al., 2012; Hambly and Sarapura, 2009). Developing countries have been implementing various policies in an attempt to remove these barriers. For example, some public programs (micro-credit and training programs) support women in fulfilling the requirements to participate in the labor market, while other public work programs create employment for women without requirements (Dejardin, 1996; Khera and Nayak, 2009; Pankaj and Tankha, 2010; Heong and Escalada, 1997; Quisumbing and Yohannes, 2005; Quisumbing and Pandolfelli, 2010; Kabeer, 2008; Mashiri et al., 2005).

The public work programs targeting women from low-income families do not require educational qualifications to participate, nor are skills requested. Participants are expected to do unskilled jobs (Del Ninno et al., 2009). However women's participation in such programs results in a reduction of their share of domestic duties (Quisumbing and Yohannes, 2005; Dejardin, 1996). Developing countries have several programs to reduce the burden of women's domestics duties and increase their participation in the labor market. Rural women in developing countries spend long hours finding and transporting water and gathering wood for fuel. These duties could be alleviated by providing every household access to tap water and subsidised cooking fuel (Panda, 2006; Dolan and Sutherland, 2002; Grown et al., 2005). Caring for children and elders are other time-intensive domestic activities. Public financing of child care and daycare facilities can increase women's participation in paid employment. For when women choose to participate in paid employment, they reduce the time spent on domestic activities.

Women are the principle development agents for their infants and children. The development goals related to child welfare depend on the status of women in society (UNICEF, 2006; Kabeer, 2008). Women's allocation of time increases the welfare of children via two channels: the income from paid work, and the time spent directly in the household with children or on other domestic activities. Women's time allocation on household activities

such as meal preparation, breastfeeding, and seeking preventive and curative medical care is vital for infants and children's health Hoffman (1989). Income earned by women is better spent on children's health and education than in households supported entirely by male income (Blumberg, 1988; Phipps and Burton, 1998). Women's access to economic resources increases the level of resource allocation to their children, but decreases the amount of time 
allocated to domestic work, including childcare. The former is called income effect, and the latter is called time effect (Popkin and Solon, 1976; Glick, 2002; Glick and Sahn, 1998).

In this paper, we examine the conflict between mothers' work and child nutrition in the world's largest public works program, the Mahatma Gandhi National Rural Employment Guarantee Act (MGNREGA) in India. In 2016, MGNREGA ranked as the world's largest public employment program for unskilled workers, with 278 million workers involved. The program's objectives are to eradicate poverty in rural India, and also to achieve empowerment of women by reserving one-third of MGNREGA employment for women and providing them equal wages to men. The phased rollout of the program allows us to conduct a difference-indifferences estimation to shed light on the question. We use the number of meals consumed by children per day as a proxy for mother's time allocated to child care, as cooking and serving meals to children is one of the most significant parts of domestic work. This proxy is based on the findings of the Time Use Survey conducted by the Ministry of Statistics and Program Implementation (MoSPI), Government of India in 1998. The Summary Results of the Time Use Survey in 1998 noted that, "women reported that they spent about 2.1 hours per day on cooking food, and about 1.1 hour on cleaning the household and utensils. Participation of men in these activities was just nominal. Taking care of children was also mainly the women's responsibility as they spent about 3.16 hours per week on these activities as compared to only 0.32 hours by males."

We find that the number of meals for preschool and school aged children decreased by 2.6 percent and 2.8 percent, respectively. These declines only happen for meals consumed at home, with no change in the number of meals consumed outside the home, or in school. Furthermore, the number of meals goes down for children in households where mothers are most likely to take up MGNREGA work - small and marginal landholder households, as well as the households in the bottom 30 percentile of consumption. Furthermore, female participation in MGNREGA is generally higher during the dry season as compared to the rainy season. We find that during the dry season, there is a negative impact on the number of meals consumed by preschool and school aged children, but no effect during the rainy season.

Although our main results suggest that the number of meals for children went down after MGNREGA, it is plausible that the higher income led to an increase in the quality of food consumed. We use a measure of food diversification at the household level for calories, proteins, and fats and find that MGNREGA led to no differential effect in the quality of food at the household level. Taken together, a decline in the quantity of food and no corresponding increase in the quality of food suggests a decline in the nutrient consumption for children. 
Finally, we look at whether the size of the household or the number of adult women in the household compensate for the decline in the number of meals consumed by children. We find suggestive evidence that the number of family members and the number of adult women partially ameliorate the negative effect on quantity of meals, but only for older children.

\subsection{MGNREGA Literature}

The MGNREGA is the largest anti-poverty programme in the world. Owing to its importance and scale, many studies have focused on various aspects of the programme. Past literature has documented effects on labor market outcomes, on poverty, women's empowerment, and intra-household decisions on child health and education. The programme has been shown to have both direct and indirect effects (general equilibrium effects) (Muralidharan et al., 2017).

MGNREGA has increased the wages for unskilled workers and crowded out private sector work, (Imbert and Papp, 2015), and the largest employment beneficiaries of the programme have been women and members of deprived social groups - Scheduled Castes and Scheduled Tribes (Klonner and Oldiges, 2014). Furthermore, the programe increased employment during the slack season for farmers, thus, addressing the problem of seasonal unemployment (Zimmermann, 2012). The reduction in seasonal unemployment due to the programme had positive effects on household consumption, during the lean season and the agricultural season (Bose, 2017). The programme also improved various dimensions of poverty, as measured by food security, financial inclusion, and mental health (Ravi and Engler, 2015).

Apart from labor market outcomes, MGNREGA has had important effects on female empowerment. The programme has been successful in erasing wage discrimination for unskilled women workers. Before the programme, female workers were paid much less than the statutory minimum wages and wages paid to their male counterparts (Azam, 2011). The programme has also improved the bargaining power of women in the household, thereby improving child welfare by increasing time spent in school (Afridi et al., 2012). Despite the evidence on the positive outcomes of the programme, a number of studies have also pointed out the difficulties faced by women participating in the MGNREGA programme, such as a reduction in leisure time for working women and workplace harassment (Pankaj and Tankha, 2010). Additionally, the MGNREGA worksites were required to provide childcare facilities in order to increase female employment. A survey of six states shows that only three percent of MGNREGA sites had access to child care facilities, and of the three percent, most child care centers were fake, only set up to impress the survey team (Khera and Nayak, 2009). 
Another study by Karak and Ray (2015) found that child care facilities were not functioning sufficiently to support women workers.

Finally, a large number of studies show evidence on the income effect of the programme on children (Afridi et al., 2012; Islam and Sivasankaran, 2014; Bose, 2017; Maity, 2015; Shah and Steinberg, 2015). However, relatively less attention has been given to the time effect (substitution effect) of the programe. Chari et al. (2019) is the first paper examining the effect of MGNREGA on women's time allocation on child care. The study finds that women participating in the public works programme reduced prenatal care and breastfeeding. Our study complements this paper by focusing on the time effect of the programe. We use the number of meals eaten by children as a proxy for time allocated by the mother for child care. We find a reduction in the number of meals for children for women participating in the programme. Thus, we argue that the absence of child care facilities at the MGNREGA worksites may have affected the children's welfare via the time effect. Furthermore, in contrast to Bose (2017) and Maity (2015) who evaluate the impact of MGNREGA on child nutrition by looking at total household consumption expenditure, our paper uses a more direct measure by focusing on the actual number of meals consumed by each child in the household.

\subsubsection{MGNREGA}

Workfare schemes aim to reduce poverty by providing minimum-wage work to poor, unemployed adults. It is a direct anti-poverty intervention. Developed and developing countries have implemented workfare programs, with workfare schemes designed to be suitable to the specific context. Since 1960, India has introduced various workfare programs to support the rural poor. In September 2005, the Indian government passed The Mahatma Gandhi National Rural Employment Guarantee Act (MGNREGA). The MGNREGA programme has a larger coverage than previous workfare programmes, and provides a statutory guarantee of up to 100 days of annual employment at the minimum wage rate to rural households willing to supply manual labor on local public works.

Adults willing to work for MGNREGA project works must apply for a job card at the Gram Panchayat responsible for their residing village administration. The Gram Panchayat must verify job card applications and issue the job card to households within 15 days of application. The job cards are issued to applicants free of cost. The job card carries the photograph of all the adult members of the household willing to work under MGNREGA projects. Jobs must be assigned to the cardholders within 15 days of submitting a job application. When work is 
not assigned to the applicants, they receive unemployment compensation. MGNREGA job applicants are hired to do unskilled works in public projects in rural area, such as water conservation, drought proofing, flood protection, land development, irrigation infrastructure and rural connectivity. All the projects must have 60:40 wage and material ratio and use of labour-displacing machinery is prohibited.

Financing of the MGNREGA projects is supported by the central and state governments. The central government's budget supports the entire cost of unskilled manual workers and 75 percent of the costs of material, and wages of skilled and semi-skilled workers. The state governments bear the remaining 25 percent. In addition, state governments bear the cost of unemployment allowance payable when the state government cannot provide wage employment on time.

Passed in September 2005, the MGNREGA was introduced throughout India in three phases, introduced in February 2006, April 2007 and April 2008 respectively. In the first phase, MGNREGA was introduced in 200 districts, 130 districts in the second phase, and the remaining 284 districts in the third phase.

In this paper, we will refer to these groups of districts as "Phase 1," "Phase 2," and "Phase 3," respectively. While the actual assignment mechanism to each phase is unknown, the government stated that an explicit goal of the roll out was to target the poorest districts first. However, it also guaranteed that each state would receive at least one district in the first phase of the program. Zimmerman (2014) argues that based on the allocation of similar programs, it is likely that states were given slots to allocate to each phase based on poverty levels. Actual allocation was likely based on the government's own "backwardness rankings," which ranks districts based on agricultural wages, percentage of scheduled caste/scheduled tribe in the district, and agricultural productivity (Planning Commission, 2003). However, this ranking does not explain allocation to each phase perfectly. 


\subsection{Empirical Strategy and Data}

\subsubsection{Empirical Strategy}

MGNREGA was rolled out in three phases across districts in India, with the first phase in February 2006 (200 districts), the second phase in April 2007 (130 districts), and finally to the rest of rural India in April 2008. Since the roll-out was done in a manner where the poorest districts received the program first, followed by richer districts, comparing the poorest districts in phase 1 to the richest districts from phase 3 would bias our estimates. Therefore, we focus on comparing the outcomes for households in phase 1 districts (treated districts) to households in phase 2 districts (control districts) before and after the first phase implementation of MGNREGA. These specifications are similar to Imbert and Papp (2015), and Shah and Steinberg (2015). We run regressions of the form:

$$
Y_{i h d t}=\alpha+\beta_{1} \delta_{d t}+\gamma_{d}+\varphi_{t}+X_{d t}^{1}+X_{h}^{2}+\varepsilon_{i j t}
$$

where $Y_{i h d t}$ is the meals consumed by child $i$ in household $h$ in district $d$ in year $t . \delta_{d t}$ is an indicator variable equal to one for Phase 1 districts in the post period (2006-07) and zero in the pre-MGNREGA period, $\gamma_{j}$ and $\varphi_{t}$ are district and year fixed effects respectively. $X_{d t}^{1}$ and $X_{h}^{2}$ are district and household level control variables. We cluster standard errors at the district level. Since we control for district fixed effects, we essentially compare outcomes in Phase 1 districts relative to Phase 2 districts before and after the introduction of MGNREGA in Phase 1 districts (2006-07).

\subsubsection{Data}

Our primary source of data is the nationally representative Consumer Expenditure Survey (CES) conducted by the National Sample Survey Organization (NSSO). CES-NSSO data reports the details of consumption on goods and services at the household level. Our paper includes nine rounds of CES-NSSO: rounds 55 (1999-2000), 56 (2000-01), 57 (2001-02), 58 (2002), 59 (2003), 60 (2004), 61 (2004-05), 62 (2005-06), and 63 (2006-07), between 1999 to 2007. Most surveys cover the full agricultural season from July of the previous year to June of the next year, except for rounds 58 and 60 that cover only half a year, and round 59 covers households from January to December. Depending on the time span of the reference period, surveying is further divided into two to four sub-rounds each lasting three months. A survey 
with a length of half-year (a year) reference period falls into two (four) sub-rounds. Each sub-round has an equal share in the total number of households surveyed. The CES-NSSO rounds 55 to 63 cover every quarter between July 1999 to June 2007. Furthermore, NSSO provides sampling weights for all individuals that we use to calculate summary statistics as well as in our regression specifications.

Importantly for our paper, the NSSO data collects socio-demographic indicators and the average number of meals consumed by each member of the household in the last 30 days. The number of meals consumed by children (a proxy for mother care) is our main outcome variable of interest. This is the only food consumption indicator available at the individual level, whereas all the other consumption indicators are at the household level. Figure 2.1 plots that meals consumed on average by children in different age groups across 3 years in our data set. It is interesting to note that the number of meals consumed steadily rises for the children between 1 and 12 years old over the years. For adolescents and adults, there is no change in meals consumption over our sample period.

Figure 2.1: Meals intake

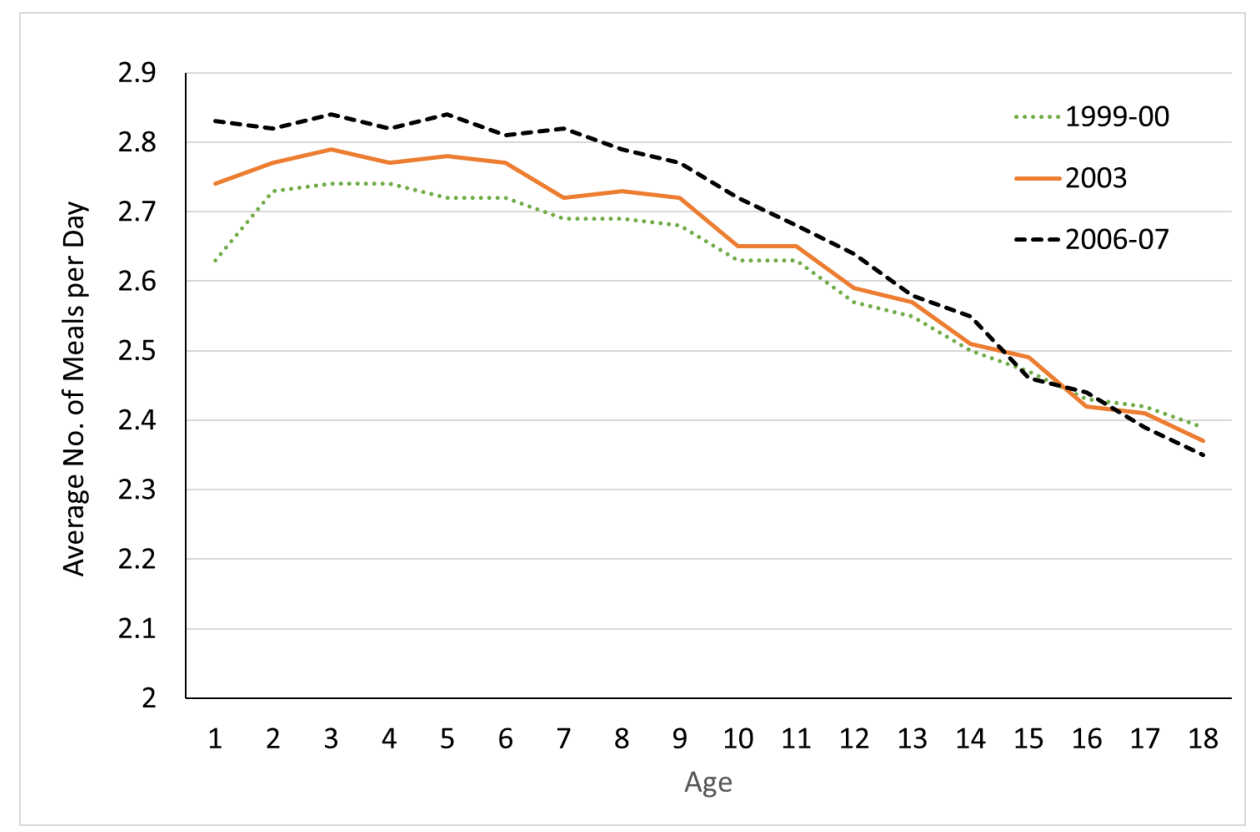

Source: Author's calculation using various rounds of CES-NSSO.

We use multiple control variables from CES-NSSO such as household type, social group, religion, and gender. Household type classifies rural households into five groups; agricultural laborer; non-agricultural laborer; self-employed in agriculture; self-employed in non- 
agriculture; and others/not elsewhere classified. There are four social groups in the data: scheduled tribes; scheduled castes; other "backward classes"; and others, who more advanced socially and educationally. Households are also grouped according to their religious beliefs Hinduism, Christianity, Islam, and others.

We also control for district level time-variant characteristics such as district-level nightlights data, constructed using the method of (Henderson et al., 2012), as well as district GDP data $^{2}$.

We present descriptive statistics of the outcome variables and selected control variables for Phase 1 districts and Phase 2 districts in the pre-program period (2004-05) in Table 2.1. The primary outcome variable we use in the analysis is the average number of meals for children of different age groups. In general, children aged between 1 and 14 require more meals than do teenagers (see Figure 2.1). We divide the children aged between 1 and 18 into three groups based on the stages of child development: a) preschool children between 1 and 5 years old, b) school-going children between 6 and 14 and c) teenagers between 15 to 18 years of age.

\footnotetext{
${ }^{2}$ We use district level GDP data from the Planning Commission of India.
} 
Table 2.1: Pre-program Summary Statistics for Phase 1 and Phase 2 Districts (2004)

\begin{tabular}{|c|c|c|c|}
\hline & Phase 1 & Phase 2 & p-value \\
\hline & (1) & $(2)$ & $(3)$ \\
\hline Average Meals per day (age 1- 5) & 2.824 & 2.828 & 0.929 \\
\hline Average Meals per day (age 6-14) & 2.718 & 2.717 & 0.988 \\
\hline Average meals per day (age $15-18$ ) & 2.369 & 2.434 & 0.255 \\
\hline Calorie diversification index & 0.363 & 0.343 & 0.244 \\
\hline Protein diversification index & 0.361 & 0.341 & 0.226 \\
\hline Fat diversification index & 0.392 & 0.387 & 0.700 \\
\hline \multicolumn{4}{|l|}{ Social group: } \\
\hline Fraction scheduled tribes (SC) & 0.203 & 0.235 & 0.506 \\
\hline Fraction scheduled castes (ST) & 0.170 & 0.086 & 0.025 \\
\hline Fraction other backward castes (OBC) & 0.409 & 0.417 & 0.884 \\
\hline Fraction other castes & 0.219 & 0.261 & 0.390 \\
\hline \multicolumn{4}{|l|}{ Household type: } \\
\hline Fraction agricultural labourer & 0.266 & 0.271 & 0.915 \\
\hline Fraction non-agricultural labourer & 0.090 & 0.087 & 0.924 \\
\hline Fraction self-employed in non-agriculture & 0.159 & 0.165 & 0.893 \\
\hline Fraction self-employed in agriculture & 0.407 & 0.398 & 0.864 \\
\hline Fraction other household type & 0.076 & 0.077 & 0.997 \\
\hline \multicolumn{4}{|l|}{ Religion: } \\
\hline Fraction Christianity & 0.014 & 0.018 & 0.772 \\
\hline Fraction Hinduism & 0.853 & 0.833 & 0.622 \\
\hline Fraction Islam & 0.116 & 0.124 & 0.820 \\
\hline Fraction other religion & 0.017 & 0.025 & 0.637 \\
\hline Fraction boy & 0.511 & 0.512 & 0.986 \\
\hline Fraction girl & 0.489 & 0.488 & 0.986 \\
\hline District Light density & 2.349 & 2.909 & 0.060 \\
\hline District GDP & 4819.793 & 6470.618 & 0.078 \\
\hline District Observations & 193 & 124 & \\
\hline Individual Observations & 131160 & 97810 & \\
\hline
\end{tabular}

Notes: This table presents means of the outcomes and control variables used in this paper. Column 1 shows the Phase 1 districts that received MGNREGA in February 2006. Column 2 includes Phase 2 districts that received the program after April 2007. Column 3 shows the p-values of the t-test of equality of means in columns 1 and 2. NSS controls are constructed using NSS employment survey data conducted during the year 2004. 
Toddlers and preschool children (1-5 years old) consume on average about 2.8 meals per days. The meal intake for school-going children aged 6-14, and adolescents aged 15-18 are 2.7 and 2.4, respectively. This pattern also confirms that younger children require more frequent meals than older children. The means in meals consumed per day are similar between Phase 1 districts and Phase 2 districts for all groups of children in the pre-program period (Table 2.1).

The number of meals consumed per day is the only food consumption related variable reported for each member in the household in the NSS consumer expenditure survey. Other details relating to food consumption reported in the survey are given as totals for the entire household. A mother participating in the labor force decides to allocate time between market work and domestic chores, including preparing meals for children. Although, a mother taking part in a workfare program has less time available for domestic duties than a non-working mother, but an increase in the purchasing power for the working mother may lead her (or the household) to purchase a variety of food items for the children and the family. To test for this hypothesis, we constructed a food diversification index at the household level. We use a Herfindahl index to look at the diversity of the consumption bundle for various macronutrients at the household level: calories, proteins, and fat. The index values lie between 0 and 1 . A value close to one in the diversification index indicates that the family depends on a few food items to meet their macro-nutrients needs. The mean values of food diversification indices are comparable between Phase 1 and Phase 2 districts in the pre-program period.

Means of selected macroeconomic indicators as of 2004-05, district GDP and district night light density, are statistically different between Phase 1 and Phase 2 districts. This is consistent with phase 2 districts being slightly richer in the pre-program period.

Although the means of our outcome of interest (meals consumed by children) are similar in the pre-program period, we need to check whether they were trending similarly in Phase 1 and Phase 2 districts before the introduction of MGNREGA. We check for pre-program parallel trends and present our results in the next section. 


\subsection{Results}

By law, at least a third of MGNREGA beneficiaries must be women. Women's enrollment in MGNREGA related public works in turn may reduce their time allocation for housework and childcare related activities. We test for this hypothesis with our main outcome of interest - the meals intake of children in various age groups in response to the phased roll out of MGNREGA. In our baseline specification, we estimate a difference-in-differences specification, essentially comparing the outcome of interest (meals intake of children), in districts where MGNREGA was rolled out in the first phase compared to districts where MGNREGA was rolled out in the second phase. In all the regression specifications, we control for district fixed effects, year fixed effects, household-level controls such as household size, age, type of workers in the household, gender, caste, and religion, and district-level controls such as district GDP, and district-level night time luminosity. We cluster the standard errors at the district level. Hence, our regressions look at within district changes in outcomes for children over time between phase 1 and phase 2 districts before and after the first phase of MGNREGA was introduced. 
Table 2.2: Testing for parallel trends

\begin{tabular}{lccc}
\hline & $(1)$ & $(2)$ & $(3)$ \\
\hline & \multicolumn{3}{c}{ Number of meals } \\
\hline MGNREGA X 2001 & -0.00650 & -0.0250 & -0.0318 \\
& $(0.0524)$ & $(0.0539)$ & $(0.0581)$ \\
MGNREGA X 2002 & -0.0404 & -0.0257 & -0.0327 \\
& $(0.0414)$ & $(0.0401)$ & $(0.0502)$ \\
MGNREGA X 2003 & 0.0137 & -0.0155 & -0.0375 \\
& $(0.0412)$ & $(0.0351)$ & $(0.0424)$ \\
MGNREGA X 2004 & -0.0403 & 0.000365 & 0.0102 \\
& $(0.0397)$ & $(0.0364)$ & $(0.0434)$ \\
MGNREGA X 2005 & -0.0422 & -0.0353 & -0.0451 \\
& $(0.0398)$ & $(0.0402)$ & $(0.0457)$ \\
MGNREGA X 2006 & $-0.0790^{*}$ & $-0.0863^{* *}$ & -0.0281 \\
& $(0.0440)$ & $(0.0433)$ & $(0.0557)$ \\
MGNREGA X 2007 & $-0.163^{* * *}$ & $-0.139^{* *}$ & $-0.153^{*}$ \\
& $(0.0491)$ & $(0.0604)$ & $(0.0787)$ \\
\hline Observations & 70,863 & 129,252 & 49,095 \\
R-squared & 0.210 & 0.213 & 0.351 \\
\hline District FE & yes & yes & yes \\
Year FE & yes & yes & yes \\
Household controls & yes & yes & yes \\
District controls & yes & yes & yes \\
\hline \hline
\end{tabular}

Notes: The dependent variable is the number of meals consumed by children in different age groups. The coefficients on MGNREGA X year (year $=2001-2007$ ) indicate the difference in the number of meals between Phase 1 and Phase 2 districts across the years 2001-2007. Standard errors clustered at the district level. $\mathrm{p}<0.10,{ }^{* *} \mathrm{p}<0.05,{ }^{* * *} \mathrm{p}<0.01$

Before presenting our baseline difference-in-differences results, it is important to check whether the parallel trends assumption are satisfied. In Table 2.2, we check whether the intake of meals by children in different age groups in phase 1 districts is different than those in phase 2 districts for each year between 2001 and 2007. We find no statistically significant differences in the intake of meals for children in the age group of $1-5$ in phase 1 districts compared to phase 2 districts before the introduction of MGNREGA (until 2006). However, there is a statistically significant decline in the number of meals consumed by children between 1-5, after the introduction of MGNREGA in 2006 and 2007 in phase 1 
districts relative to phase 2 districts. This relationship is mirrored by the number of meals for children between 6-14 years of age, as well as for older teenagers (15-18 years old). Table 2.2 therefore, statistically confirms that there were no differential trends in the number of meals for children in different age groups in phase 1 and phase 2 districts before the introduction of MGNREGA, and the differences only manifest after 2006. Figure 2.2 is the corresponding visual representation to Table 2.2. This provides credence to our baseline difference-in-differences regression specifications.

Figure 2.2: Estimated coefficient plots for number of meals for different age groups
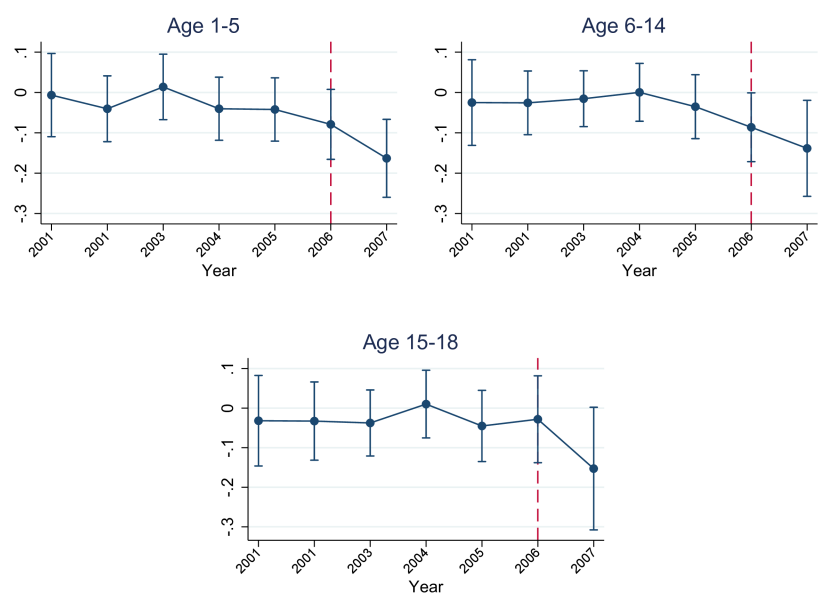

Source: Author's calculation using various rounds of CES-NSSO.

Table 2.3: MGNREGA impact on the meals intake of rural children

\begin{tabular}{lccc}
\hline & $(1)$ & $(2)$ & $(3)$ \\
\hline \multicolumn{4}{c}{ Number of meals } \\
\hline MGNREGA & $-0.0729^{* * *}$ & $-0.0803^{* * *}$ & -0.0325 \\
& $(0.0277)$ & $(0.0299)$ & $(0.0373)$ \\
\hline Observations & 70,863 & 129,252 & 49,095 \\
R-squared & 0.209 & 0.213 & 0.350 \\
\hline District FE & yes & yes & yes \\
Year FE & yes & yes & yes \\
Household controls & yes & yes & yes \\
District controls & yes & yes & yes \\
\hline \hline
\end{tabular}

Notes: *** $\mathrm{p}<0.10,{ }^{* *} \mathrm{p}<0.05$, *** $\mathrm{p}<0.01$

Standard errors clustered at the district level. 
The results from our baseline difference-in-differences specification are presented in Table 2.3. We interpret the coefficient on MGNREGA as the difference in the number of meals for children in a particular age group in phase 1 districts compared to phase 2 districts, after the introduction of MGNREGA relative to before the program. In column 1, we find that the number of meals consumed by preschool children (ages 1-5) relatively decreased by 0.073 in phase 1 districts. This corresponds to a $2.6 \%$ decline in the number of meals consumed by preschool children in phase 1 districts after MGNREGA came in to effect. In column 2, we find that the number of meals for school going children (ages 6-14) in phase 1 decreased by 0.08 after MGNREGA as compared to school going children in phase 2 districts, relative to these differences before MGNREGA. This translates in to a $2.8 \%$ decline in the number of meals for school-going children in phase 1 districts. Finally in column 3, we do not find any statistically significant decline in the number of meals for children between the ages of 15 through 18. Taken together, these results suggest that there was a decline in the number of meals consumed by preschool and school-going children in phase 1 districts relative to phase 2 districts, after the introduction of MGNREGA compared to before MGNREGA. However, there is no effect of MGNREGA on the number of meals consumed by older children in phase 1 and phase 2 districts. This is consistent with MGNREGA affecting the time allocation of women on childcare activities, as a result of which the number of meals consumed by youger children declined.

In India, meals can be consumed at home, outside the home (for example, at a neighbor's or relative's home), or at school (for example, through the midday meal scheme ${ }^{3}$ ). Since our hypothesis is that MGNREGA impacted the time allocation of women in household and childcare activities, the program should only have affected the number of meals for children at home, and not meals outside, nor in schools. In Table 2.4, we look at the differential effects of MGNREGA, on these three margins, meals at home, meals outside the home, and meals at school. We find results supporting our main hypothesis. In columns 1 through 2 , we find that the number of meals at home for children in age groups 1-5 and 6-14 declines by 0.083 and 0.089 respectively. For older children (15-18), there is no statistically significant difference as a result of MGNREGA. Importantly, we do not find any statistically significant differences in the number of meals outside the home, or at schools for children in any age group. These results also suggest that after MGNREGA, the time allocation for housework and childcare activities as measured by the number of meals for children significantly fell.

\footnotetext{
${ }^{3}$ The midday meal scheme provides free lunches for school aged children on working days in government schools. There is widespread evidence that the midday meal scheme acted as a safety net for children (?).
} 
Table 2.5: Households' landholding size: Impact on children of different age groups

\begin{tabular}{|c|c|c|c|c|c|c|}
\hline & (1) & $(2)$ & (3) & (4) & $(5)$ & (6) \\
\hline & \multicolumn{6}{|c|}{ Number of meals } \\
\hline & {$[1-5]$} & {$[6-14]$} & {$[15-18]$} & {$[1-5]$} & [6-14] & {$[15-18]$} \\
\hline \multirow[t]{2}{*}{ MGNREGA } & $-0.0707^{* *}$ & $-0.0919^{* * *}$ & -0.0409 & -0.0482 & 0.0173 & -0.0132 \\
\hline & $(0.0300)$ & $(0.0314)$ & $(0.0399)$ & $(0.0485)$ & $(0.0576)$ & $(0.0537)$ \\
\hline Observations & 56,981 & 104,753 & 38,696 & 13,637 & 24,074 & 10,250 \\
\hline R-squared & 0.217 & 0.217 & 0.355 & 0.226 & 0.271 & 0.423 \\
\hline District FE & yes & yes & yes & yes & yes & yes \\
\hline Year FE & yes & yes & yes & yes & yes & yes \\
\hline Household controls & yes & yes & yes & yes & yes & yes \\
\hline District controls & yes & yes & yes & yes & yes & yes \\
\hline Sample & \multicolumn{3}{|c|}{ Small and Marginal Landholders } & \multicolumn{3}{|c|}{ Large Landholders } \\
\hline
\end{tabular}

In Table 2.5, we divide the sample by landholding size. Small and marginal landholders in our sample own up to 2 hectares of land, whereas large landholders own greater than 2 hectares. MGNREGA should have a differential impact on small and marginal landholders, as households in this group are more likely to seek employment through the program as compared to large landholders. Columns 1-3 restrict the sample to small and marginal landholders, whereas columns 4-6 restrict the sample to large landholders. In column 1 and 2, we find that after MGNREGA, there was a relative decline in the number of meals consumed by children of small and marginal landholding families in age groups 1-5 and 6-14 by 0.07 and 0.09 respectively, in phase 1 compared to phase 2 districts. There was however no decline in the number of meals for older teens (15-18 years) in these families (column 3). Reassuringly, we find no differential effects in the number of meals consumed by children in large landholding households in columns 4-6. In the same spirit, we also split our sample by household consumption percentiles in Table 2.6, where we hypothesize that MGNREGA should differentially affect households in the bottom 30 percentile of consumption. In Table 2.6, columns 1 through 3, we look at the impact of MGNREGA on meals consumed by children in different age groups in households in the bottom $30 \%$ of consumption. In columns 4 through 6, we look at the outcome for households in the middle consumption percentiles (30-60\%) of consumption, and finally in columns 7 through 9 on households in the top consumption percentiles (60-90\%) of consumption. Similar to the results in Table 2.5, we find a significant decline in the number of meals consumed by preschool (column 1) and school-going children 
(column 2) in phase 1 districts compared to phase 2 districts as a result of MGNREGA. We do not find any statistically significant difference between children in the age group of 15 through 18 between phase 1 and phase 2 districts due to MGNREGA. In columns 3 through 9 , we do not find any statistically significant difference in the number of meals consumed by children of different age groups in households in the middle group (30-60\%) or the top group (60-90\%) of consumption. This strengthens our main results that MGNREGA resulted in a reduction in the number of meals consumed for ages 1 through 14, especially in households that were mostly likely to be affected by the program, i.e. the bottom $30 \%$ of households. These results also confirm our main hypothesis.

Table 2.7: Impact on households during dry and rainy season

\begin{tabular}{lcccccc}
\hline & $(1)$ & $(2)$ & $(3)$ & $(4)$ & $(5)$ & $(6)$ \\
\hline & \multicolumn{7}{c}{ Number of meals } \\
\hline MGNREGA & $-0.0728^{* *}$ & $-0.124^{* * *}$ & -0.0481 & -0.0507 & -0.0067 & -0.0248 \\
& $(0.0339)$ & $(0.0351)$ & $(0.0471)$ & $(0.0389)$ & $(0.0435)$ & $(0.0516)$ \\
\hline Observations & 37,327 & 67,339 & 25,402 & 33,536 & 61,913 & 23,693 \\
R-squared & 0.250 & 0.253 & 0.397 & 0.220 & 0.216 & 0.356 \\
\hline District FE & yes & yes & yes & yes & yes & yes \\
Year FE & yes & yes & yes & yes & yes & yes \\
Household controls & yes & yes & yes & yes & yes & yes \\
District controls & yes & yes & yes & yes & yes & yes \\
Sample & & Dry season & & & Rainy season \\
\hline \hline
\end{tabular}

Notes: *** $\mathrm{p}<0.01, * * \mathrm{p}<0.05, * \mathrm{p}<0.1$

Standard errors clustered at the district level.

Next, in Table 2.7, we look at the impact of MGNREGA on children across phase 1 and phase 2 districts in dry and rainy seasons of the year separately. This follows from Imbert and Papp (2015) who find that take-up of public work employment was higher during the dry season than during the rainy season. Thus, we expect to find a larger impact of MGNREGA on meals consumed by children during the dry season than during the rainy season. In columns 1 through 3, we focus on children in different age groups in the dry season (January to June). In columns 4 through 6 , we focus on children in different age groups in the rainy season (July to December). We find that during the dry season (columns 1 through 3 ), there is a significantly negative impact on the number of meals consumed by children, whereas during the rainy season, we find no statistically significant differences. Taken together, these results strengthen our conclusion that MGNREGA significantly reduced the time allocated 
for household work including taking care of children.

Table 2.8: Impact on quality of food (food diversification) of households

\begin{tabular}{lccc}
\hline & $(1)$ & $(2)$ & $(3)$ \\
\hline Calorie & Protein & Fat \\
\hline MGNREGA & -0.00673 & -0.00459 & 0.00659 \\
& $(0.00801)$ & $(0.00811)$ & $(0.00522)$ \\
\hline R-squared & 116,073 & 116,073 & 116,073 \\
\hline District FE & 0.359 & 0.299 & 0.263 \\
Year FE & yes & yes & yes \\
Household controls & yes & yes & yes \\
District controls & yes & yes & yes \\
\hline \hline
\end{tabular}

Notes: ${ }^{* * *} \mathrm{p}<0.01,{ }^{* *} \mathrm{p}<0.05,{ }^{*} \mathrm{p}<0.1$

Standard errors clustered at the district level.

Having focused thus far on the number of meals, next we look at the quality of food (food diversification) in Table 2.8. Since the quantity of meals declined post-MGNREGA, one could imagine a situation that the higher income from MGNREGA may have resulted in an increase in the quality of food (income effect). We use a measure food diversification at the household level for calories, proteins, and fats to proxy for the quality (nutritious value) of food. We convert the household's food items consumption to macronutrients using the conversion factors reported in NSSO thick surveys ${ }^{4}$. In Table 2.8, we find no evidence for an improvement in the quality of food intake at the household level.

\footnotetext{
${ }^{4}$ NSSO follows the conversion factor of C. Gopalan, B.V. Ramasastry and S.C. Balasubramanian, revised and updated by B.S. Narasinga, Y.G. Deosthale and K.C. Pant (Gopalan et al., 1991, 2000; Narasingha Rao et al., 1989).
} 
Table 2.9: Impact on the meals intake of rural children: household size and women in the family

\begin{tabular}{|c|c|c|c|c|c|c|}
\hline & (1) & $(2)$ & $(3)$ & $(4)$ & $(5)$ & (6) \\
\hline & \multicolumn{6}{|c|}{ Number of meals } \\
\hline & {$[1-5]$} & {$[6-14]$} & [15-18] & {$[1-5]$} & {$[6-14]$} & {$[15-18]$} \\
\hline \multirow[t]{2}{*}{ MGNREGA } & $-0.110^{*}$ & $-0.160^{* * *}$ & $-0.142^{*}$ & $-0.0793^{*}$ & $-0.121^{* *}$ & $-0.109 *$ \\
\hline & $(0.0574)$ & $(0.0517)$ & $(0.0798)$ & $(0.0469)$ & $(0.0486)$ & $(0.0632)$ \\
\hline \multirow{2}{*}{ MGNREGA X HHsize } & 0.00556 & $0.0121^{*}$ & $0.0178^{*}$ & & & \\
\hline & $(0.00734)$ & $(0.00641)$ & $(0.0104)$ & & & \\
\hline \multirow[t]{2}{*}{ MGNREGA X No. of women } & & & & 0.00440 & 0.0281 & $0.0529^{*}$ \\
\hline & & & & $(0.0226)$ & $(0.0226)$ & $(0.0296)$ \\
\hline Observations & 70,863 & 129,252 & 49,095 & 70,863 & 129,252 & 49,095 \\
\hline R-squared & 0.210 & 0.213 & 0.350 & 0.210 & 0.213 & 0.350 \\
\hline District FE & yes & yes & yes & yes & yes & yes \\
\hline Year FE & yes & yes & yes & yes & yes & yes \\
\hline Household controls & yes & yes & yes & yes & yes & yes \\
\hline District controls & yes & yes & yes & yes & yes & yes \\
\hline
\end{tabular}

Standard errors clustered at the district level.

In India, rural households often live in a joint family setting with many adult household members. Since MGNREGA guarantees one hundred days of employment per household, at any point in time, a larger household would have some members who are not involved in MGNREGA work. For example, Shah and Steinberg (2015) find that adolescent girls are more likely to substitute for their mothers in domestic work in response to MGNREGA. Thus, in a larger household, there would be some members available to pick up the slack in household and childcare related activities. We test for this hypothesis next. In Table 2.9, we test whether the household size or the number of adult females in the household ameliorates the negative effect of MGNREGA on meals consumed by children in different age groups. In columns 1-3, we look at whether the household size has a compensating effect on the number of meals consumed by children in age groups 1-5, 6-14, and 15-18. Essentially, we are concerned with the coefficient on MGNREGA X HHSize. We find that the household size partially compensates for the number of meals consumed by older children (ages 6-14 and 15-18), but has no effect on the number of meals of young children (ages 1-5). In columns 4-6, we look at the compensating effect of the number of adult women in the household - the coefficient on MGNREGA X No. of women. We find that the number of adult women only compensates for the number of meals consumed by older children (age group 15-18), but has 
no effect on meals for children in other age groups. Taken together, our results suggest that the household size or the number of adult women in the household only partially attenuates the negative effect of MGNREGA on the number of meals consumed. Furthermore, this compensating effect only happens for older children, with no effect on the younger kids (age group 1-5).

Table 2.10: Impact on children from urban households

\begin{tabular}{|c|c|c|c|}
\hline & (1) & $(2)$ & $(3)$ \\
\hline & \multicolumn{3}{|c|}{ Number of meals } \\
\hline & {$[1-5]$} & {$[6-14]$} & [15-18] \\
\hline \multirow[t]{2}{*}{ MGNREGA } & -0.0341 & 0.00701 & -0.0420 \\
\hline & $(0.0407)$ & $(0.0336)$ & $(0.0340)$ \\
\hline Observations & 28,636 & 59,332 & 27,639 \\
\hline R-squared & 0.318 & 0.299 & 0.402 \\
\hline District FE & yes & yes & yes \\
\hline Year FE & yes & yes & yes \\
\hline Household controls & yes & yes & yes \\
\hline District controls & yes & yes & yes \\
\hline
\end{tabular}

Finally, in Table 2.10, we carry out a falsification test. Since MGNREGA was introduced in the rural parts of the districts it should not have affected the urban households. We check whether MGNREGA affected the number of meals of children amongst the urban households. We find no differential effect on the number of meals consumed by children in the different age groups in urban areas. This validates our findings of the effects of MGNREGA on child meal intake. 


\subsection{Conclusions}

Women play a central role in their child's health and education. As women enter the work force their time allocated to household and child care activities will invariably go down. Although child welfare may go up due to the mother's income from paid work, previous work has shown that Indian women are doing unskilled jobs during periods of adverse economic shocks, rather than because of good economic opportunities (Klasen and Pieters, 2012). In this paper, we examine the conflict between mother's work and child nutrition in the world's largest public works program, the Mahatma Gandhi National Rural Employment Guarantee Act MGNREGA in India. Using the phase-wise roll out of the program across districts and a difference-in-differences design, we find that female participation in MGNREGA reduces the number of meals consumed by preschool and school-going children. The negative effects are partially attenuated by more members at home, albeit only for older children. However, adequate public investment in childcare services at the work site may alleviate the potential negative effects of the trade-off between mother's work and child nutrition. Future work needs to focus on the effects of female friendly workplace investments and their effects on household and child welfare, especially with increasing employment opportunities for women in developing countries (Gaddis and Klasen, 2011). 


\title{
Chapter 3
}

\section{Women's political representation and educational attainments: A district-level analysis in India ${ }^{1}$}

\begin{abstract}
This paper has two major objectives: (1) to analyze whether the gender of politicians in India is relevant to the educational achievements of the residents of the districts in which they were elected; (2) to test whether politicians are more sensitive to the needs of people of the same gender. By applying econometric techniques to a dataset obtained by merging individual with district-level political data, we concluded that an increase by 10 percentage points in women's political representation produces an increase by 6 percentage points in the probability of children completing primary school. We then found gender-differentiated results: women's political representation affects significantly more girls' than boys' education. Finally, the paper provides further evidence of the benefits of women's political representation and argues that, in order to increase the latter, an integrated approach, going beyond isolated gender quotas, is required.
\end{abstract}

Key words: Women political representation, children schooling. JEL code: I20, I24, I38

\footnotetext{
${ }^{1}$ The chapter is based on joint work with Francesco Burchi. We would like to thank the German Federal Ministry for Economic Cooperation and Development (BMZ) for funding this study as part of the research project on the political economy of inclusive growth. We also would like to express our gratitude to Markus Loewe, Tilman Altenburg, Luis Camacho, Imme Scholz, and Giorgio D'Agostino for commenting on various versions of the paper.
} 


\subsection{Introduction}

During the past two decades, a growing body of literature has investigated the effects of women's political representation on a range of economic, political and social indicators. These studies have focused on high-income countries, as well as middle-income and low-income countries (Powley, 2007; Panday, 2008). The empirical evidence has been drawn mostly from countries that have set more or less explicit gender quotas in national or sub-national assemblies or administrations.

In the literature on political economy, the 'citizen-candidate model' views the identity of politicians as being one of the fundamental determinants of investment choices (Osborne and Slivinski, 1996). Building on these models, scholars have investigated the specific role played by politicians' gender in policy-making (Chattopadhyay and Duflo, 2004b; Bardhan et al., 2010a). Men and women are assumed to have different preferences, and this is taken as being why they make different choices once they obtain important political tasks. While most of the empirical studies based on these assumptions do not clearly define the nature of these differences.

This paper looks at the relationship between female political representation and educational achievements in India. One important reason for focusing on this country is the fact that the Indian parliament is currently debating the possibility of reserving a proportion of seats in state assemblies for women. While most of the existing literature focuses on the lowest administrative level, i.e. the Gram panchayat ${ }^{2}$, or on the states, our analysis looks at the relationship in state assembly constituencies. State assembly constituency politics has not been examined in great detail thus far. Given the lack of data on educational outcomes, we cannot fully run a constituency-level analysis, but need to aggregate information at district level.

In detail, this paper tries to answer three questions. The first one is: Does women's political representation have a positive effect on primary education completion rates? Our aim is to test whether women pay more attention to education and try to divert more resources to this sector. If so, this should be reflected by higher school completion rates. This topic has been little explored to date: to the best of our knowledge, only one paper Clots-Figueras (2012) has studied this relationship in India. (Clots-Figueras, 2012) studies the period between 1970 and 1992. In the late 1990s, many other state governments allocated discretionary funds to

\footnotetext{
${ }^{2}$ The Gram Panchayat is a local self-government at the village or small town level in India. This is the lowest tier of Panchayat Raj Institutions, a complex multi-level governance system with responsibilities of civic administration and independent, though limited, power of taxation.
} 
MLAs, known as the MLA Local Area Development Scheme Fund (MLALADS). This fund has given space to politicians to execute preferred polices at their constituency.

The two other research questions are: a) Does women's political representation affect girls' more than boys' probability to attain primary education? This way, we verify whether female politicians pay more attention to the education of girls; b) What are the possible channels through which women's political representation affects educational achievements? Given data constraints, we investigated only a few possible channels, such as the availability of schools - already examined, for example, by (Clots-Figueras, 2012) - and the coverage of the Mid-Day Meal (MDM) scheme, never explored in the literature. The MDM scheme is a very large school feeding program that has boosted primary school attendance (Afridi, 2011; Drèze and Goyal, 2003), especially among girls. The main hypothesis is that female politicians pay more attention than male politicians to this welfare program, thus improving educational attainment through this particular channel. However, in case of positive pro-female effects, a possibility is the existence of a role model effect: girls' educational aspirations and, as a consequence, educational outcomes can increase as a result of seeing women undertaking important tasks in society. Unfortunately, we cannot directly test this hypothesis empirically.

In order to answer these three questions we constructed a complex database. Following the previous work of Clots-Figueras (2012), we combined individual data from a nationally representative survey conducted by the National Sample Survey Office (NSSO) with constituency-level information from the Election Commission of India, which was aggregated at district level. As for this district-level dataset, we extended Clots-Figueras' database: while she uses data for the 1970-1992 period, our information covers the 1970-2003 period. The household-level data come from the 68th NSSO survey (2011-2012), while Clots-Figueras (2012) used the 55th NSSO survey (1999-2000).

In order to overcome a major 'omitted variables' bias, due to the fact that more progressive districts are more likely to have more women in political bodies and to invest more in education, our econometric strategy is based on an instrumental variable (IV) approach. Thus, the proportion of district seats won by women was instrumented by the share of district constituencies won by women in close male-female contests, i.e. in elections in which there was a narrow gap between the winner and the runner-up. 
The paper is divided into six sections. Section 3.2 presents evidence of the relationship between women's political representation and development in India. Section 3.3 concentrates on the political economy of education and illustrates the conceptual framework. The data and variables are presented in Section 3.4. Section 3.5 sets out the results of the quantitative analyses. Finally, the concluding remarks and policy recommendations are presented in Section 3.6.

\subsection{Women's Representation in Politics, Policy-making and Development Out- comes}

This Section reviews the evidence of the multiple effects of female political roles -both as members of executive bodies and as members of legislative assemblies - at different levels in India, i.e. state, district and local. Most studies concentrate on the lowest administrative level, the Gram panchayat (GP), because the 73rd Amendment of the Indian Constitution (1992) stipulates that one third of the seats in local councils and one third of local leaders' posts (known as pradhan or sarpanch, depending on the state) in rural areas must be reserved for women. The decision on which gram panchayat (GP) is to be reserved for women is 'random', i.e. independent of any village-specific characteristics. In particular, this means that women are also elected in villages with a female-hostile electorate. This allows a straight comparison to be made in terms of development inputs and outcomes between 'reserved' and 'unreserved' villages, allowing the differences to be attributed to the political leader's gender. For this reason, many scholars have exploited this unique research design.

The studies fall into two groups: (1) those looking at the influence of women's political representation on 'input' indicators, i.e. investment choices, use of budgets and management of welfare programs; (2) those analyzing the impact of women's political representation on multiple development 'outcomes' (Burchi and De Muro, 2016).

\subsubsection{Women's political representation and policy-making}

\section{Provision of public goods}

In a highly influential study in West Bengal and Rajasthan, Chattopadhyay and Duflo (2004b) concluded that "there are significantly more investments in drinking water in GPs reserved for women'. Moreover, reserved villages were found to invest less in public goods 
more of interest for men, e.g. roads in Rajasthan. Controlling for several characteristics of the pradhan, Chattopadhyay and Duflo (2004b) confirm that it is its gender that explains the differences in terms of the provision of public goods. In line with Chattopadhyay and Duflo (2004b) and Beaman et al. (2010) found that female leaders invested more in drinking water facilities and that the overall quantity of public goods was significantly higher in reserved villages, while the quality of public goods was higher, though not statistically significantly, in reserved villages. A study in the state of Karnataka produced opposite results: the quality of rural services appeared to be better in male-led villages (Raabe et al., 2009).

Deininger et al. (2015) ) used survey data for 233 villages, to test whether there was a difference between reserved and unreserved villages in terms of the quality of public goods delivered, as measured by self-reported data. Their findings differed somewhat from those of other scholars, as they reported reservation as having an adverse effect on the quality of public goods. However, an in-depth analysis, which accounted for other characteristics of the leader, showed that the main factor is the leader's lack of experience (rather than its gender).

Using state panel data for 1967-2001, Clots-Figueras (2011) focused on women's representation in state assemblies, educational public goods and health-related public goods. Her empirical study showed that female political representation is positively associated with the number of schools (particularly primary schools) and with several health inputs.

\section{Expenditures}

The gender of political leaders and legislators does not appear to have any relevant effect on the use made of budgets. The study by Raabe et al. (2009) in Karnataka showed there was no substantial difference in the use made of GPs' own resources: health and education are priorities in both reserved and unreserved villages. Similar results were obtained by Rajaraman and Gupta (2012) in four Indian states. Their study suggested that the gender of the sarpanch does not affect the likelihood of funds being spent on water, traditionally a more female-sensitive sector. In line with the above papers, Clots-Figueras (2012) showed that the proportion of female politicians in state assemblies does not affect budget allocation, either at aggregate level or in sectors such as health and education. 


\section{Corruption}

A study by Bardhan et al. (2005) found contradictory evidence of the impact of political reservation on the targeting of anti-poverty interventions: depending on the specific intervention, targeting was better, worse or not significantly different in reserved villages compared to non-reserved ones. Using data from the same Indian villages, but based on survey data rather than administrative data, Bardhan et al. (2010b) still did not find any evidence of better targeting in reserved villages. In a comprehensive study in Andhra Pradesh, Afridi

et al. (2013) initially found that the presence of female pradhans increased corruption in the management of the National Rural Employment Guarantee scheme. When the leader's other characteristics were factored into econometric models, however, it became clear that the problem is female leaders' lack of experience rather than their gender. By contrast, Beaman et al. (2010) found that fewer bribes were paid in reserved councils.

\subsubsection{Development outputs and outcomes}

\section{Health}

Dongre (2010) identified a negative and statistically significant relationship between women's reservation and the prevalence of diarrhea in Andhra Pradesh. There is also some evidence of a positive effect of women's political representation on many health-seeking behaviours and health conditions (Bhalotra and Clots-Figueras, 2014).

\section{Education}

To the best of our knowledge, not one paper has looked at the effects of female reservation in Indian GPs - whether as local leaders or as council members - on educational outcome indicators, such as school completion rates or children's learning abilities. Only a study by Binswanger-Mkhize et al. (2012) examined the impact of women's reservation on access to primary education, finding a positive relationship.

Clots-Figueras (2012), on the other hand, investigated whether the educational level of district residents is a function of women's political representation immediately before they enrolled at primary school. She found empirical evidence of a strong, positive relationship in urban areas, but not significant in rural areas. The author's interpretation was that women 
assigned greater value to education in urban areas because of the higher expected returns.

\section{Participation in political life and women's empowerment}

Several studies have investigated whether female reservation enhances women's ability to take part in political life, broadly speaking. Most papers found empirical evidence that female leaders had a positive effect on attendance of village meetings, with special reference to women (Chattopadhyay and Duflo, 2004b; Beaman et al., 2010), and even on active political participation (Deininger et al., 2015). By contrast, Raabe et al. (2009) found male attendance to be slightly higher in reserved GPs, while female attendance was very low in both types of village. Finally, some studies conducted in southern states concluded that reservation did not affect the likelihood of village meetings being held or the probability of people attending them (Besley et al., 2005; Ban and Rao, 2008).

\subsection{The Political Economy of Education}

Most of the above papers also sought to test the validity of two alternative political economy models, namely the Downsian model (Downs, 1957) and the citizen-candidate model. The first type of model assumes that, once elected, leaders commit to the policies that favour the median voter. In other words, the identity of the political leader is assumed not to play a role. By contrast, the citizen-candidate models (Besley and Coate, 1997; Osborne and Slivinski, 1996) assume that political leaders will not simply comply with the wishes of the median voter: therefore, these models acknowledge that the identity of political leaders affects policymaking. Gender is regarded as a fundamental component of a leader's identity: thus, female leaders will make policies that favour women and what women care about.

The present paper joins the literature on the effects of women's political representation, placing the emphasis on basic education. Education enhances employability and income and is a key driver of health, nutrition and participation in public life (Sen, 1999). Moreover, the educational system in India has several problems. While overall educational performance is gradually improving and does not collocate India in the lowest group, there are high levels of inequality across people, between men and women, and between social groups (CrespoCuaresma et al., 2013). Current studies on India do not provide robust evidence of the role 
played by women's political representation in the educational sector. One study in Rajasthan, for example, shows that in villages headed by women politicians the village meetings do not dedicate more attention to education (Bonu et al., 2011). Higher female political representation seems to correlate positively with input indicators related to the quality of educational services.

However, none of the studies on India has actually examined whether women's representation in turn affects educational outcomes such as school completion rates or learning abilities. The only exceptions are the studies by Clots-Figueras (2012) and by Beaman et al. (2012), which point, respectively, to a significant relationship only in urban areas and only for girls.

Many previous studies tried to exploit the randomization of the reservation of GP seats for women to identify differences in policy-making and outcomes. However, there are two main limitations in the studies focusing on this administrative level: (a) in practice, some states allocate very limited funds and responsibilities to panchayats (Planning Commission, 2011); (b) reservation creates a strong selection bias as women leaders have less political experience and lower education: only a small number of papers published to date use reliable data that take account of these factors.

This paper, instead, focuses on the state assembly constituencies, which are the level just below the district. In the states assembly elections, there is no reservation policy for women. The elected representative of the state assembly constituency is called member of legislative assembly (MLA). MLAs have a legislative role in the state assembly, but are also the second most powerful politician in the assembly constituency after the member of parliament (MP). The study by (Jensenius and Suryanarayan, 2015) find that MLA's time allocation in legislative activities has declined. In contrast, their activities at the level of constituency have significantly increased. MLAs play an active role addressing their constituency related matters by making requests to bureaucrats or cabinet ministers on behalf of the constituency (Asher and Novosad, 2017). Overall, they have a significant degree of control over federallyappointed bureaucrats (Iyer et al., 2013). Given that the provision of several public services in India is administrated at district level (Betancourt and Gleason, 2000), MLAs often write to senior district officials in order to improve the quality of these services in their constituency. For example, education, which is predominantly under the responsibility of the State governments, is monitored and administrated at district level through the district education office. Therefore, MLAs' political power plays a vital role in improving the educational outcomes of people living in their constituency. For this study, however, we cannot fully run our analysis at constituency level because we do not have individual data on educational variables for this 
administrative level (see Section 3.4). We rely on information aggregated at district level. In particular, the information on election results is taken from the constituencies information and then aggregated for the district.

In our work, we analyze the effect of women's political representation on the probability of children completing primary education. We also investigate whether this effect is genderdifferentiated. In case of a positive, gender-neutral effect, we then verify possible channels that mediate this relationship. Due to several data constraints, we could explore only two main channels, i.e. the presence of school buildings and the coverage of the Mid-Day Meal Scheme (MDM). The latter is the world's largest school meals program and has a twofold objective: raising school attendance and improving the nutrition of primary school children. A series of studies has already demonstrated that this program has a positive effect on school attendance and completion (Drèze and Goyal, 2003; Singh et al., 2013). However, there is high heterogeneity in the management and implementation of this scheme throughout India. Several challenges were encountered in implementing the MDM in the schools, such as poor nutritional contents of the meal, contaminated food, and the lack of proper kitchens, store rooms and access to clean water supply in the school, which negatively affected the quality of the meals provided (Sahai, 2014). On behalf of their constituency, MLAs have the political power to ensure a better functioning of welfare programs, such as the MDM.

We consider politicians' gender to be an important aspect, together with other identityrelated factors such as membership of a caste, religious group or party. Our hypothesis is that women attach a higher value to education (and primary education in particular) than men do. In consequence, districts with more female MLAs will tend to invest more in this sector and pay more attention to programs like the MDM.

Unlike other scholars, we do not regard women as a homogenous interest group that seeks to maximise its utility, i.e. to improve female-sensitive sectors such as education. We do not argue that education is universally more important for women than for men, as this would imply that the nature of the gender difference is 'biological' or 'due to nature'. If the gender of a political leader matters for policy-making, this is due to the 'social' positioning of women. Women in India lead very different lives from men. As the main carers of children, they know better and care more about children's well-being (including their education). Empirical studies in India, based on both quantitative and qualitative information, support the idea that female politicians care more about education than male politicians (Singh and Pundir, 2002; Jayal, 2006; Raabe et al., 2009) ${ }^{3}$. As the nature of these differences is not biological,

\footnotetext{
${ }^{3}$ In an extensive survey conducted by the World Bank, the Institute of Rural Management Anand (IRMA), the Indian
} 
this assumption might easily not work in a different context than India, where culture, family structures, and social norms are different.

Finally, factors other than a commitment to and investment in education may affect the intensity and even the direction of the relationship between women's political representation and education. Good examples would be women's capacity to implement adequate educational policies and their effective ability to express themselves in a district's political environment dominated by men. The former is a serious problem in many GPs, as reservation has often brought inexperienced women to power in female-reserved villages. In our case, women run in fully competitive state elections, so there is no reason to expect a substantial gender difference in terms of the ability to implement educational.

In case of a positive effect of women's political representation on school completion only among girls, there are three main possible explanations. The first is that, again for social reasons, female politicians really make the interests of other women/girls: as they are often marginalized themselves, they might care more about education as a tool for emancipation for the vulnerable groups, such as other women, girls and members of underprivileged castes. It is, however, difficult to test it. In general, an improvement of the management of the MDM could be a mediating channel since the studies of Afridi (2011) and Singh and Gupta (2015) show that this welfare program has a significantly larger impact on girls' education. We also disaggregate the information on the coverage of MDM by gender to verify whether there is a pro-female bias in the coverage of the program in districts characterized by more women in politics.

A second explanation is the presence of role model effects: female politicians may not differ from male politicians with regard to the policy-making, but the simple fact that girls see women in important political positions may increase their ambitions and push them to stay longer in school. The presence of this role model effects has been already found in other studies in India (Beaman et al., 2012). In order to verify this hypothesis, we would need, for example, data on girls' educational aspirations, which unfortunately are missing.

\footnotetext{
Ministry of Rural Development and the German Development Institute (DIE) in 9 Indian states it emerges that in villages where the local leaders are women, education appears significantly higher in the ranking of village priorities. The probability that education is considered important or extremely important is significantly higher in villages reserved for women (100\%) as compared to non-reserved villages (82.5\%).
} 


\subsection{Data and Methods}

\subsubsection{Dataset}

This paper combines data from two main sources. The first is the, 2011-2012 National Sample Survey Office (NSSO) Survey on Employment and Unemployment conducted by the Indian Ministry of Statistics. This nationally representative household survey contains sociodemographic information, including a section on education. We restricted our sample to individuals aged 14 or older, assuming that it would be 'normal' to have completed primary school by that age. Children are supposed to start primary school at the age of six. Depending on the state, primary education lasts for either four or five years. Accounting for some late starts and resits (lasting 1 or 2 years), we decided to set the threshold at the age of 14 .

The second source is the database of political variables provided by Clots-Figueras (2012). ${ }^{4}$ The author collected extensive information on election results in each constituency, from the statistical reports published by the Election Commissions of India for the 16 biggest states. Elections are held regularly in each constituency, resulting in one of the candidates winning the corresponding seat in the state assembly. These data were aggregated to create districtlevel indicators, such as the proportion of district seats won by women. Since Clots-Figueras' database only covers the 1967-2001 period, we extended it to the years 2002 and 2003, years in which 6 states held elections.

We then merged the datasets using two identifiers, i.e. the district $\operatorname{code}^{5}$ and the year in which the individual started primary education, i.e. when he or she was six years old. Our unit of analysis is therefore the individual. His or her characteristics are linked to the political information for the district in which he/she lived at the age of $\operatorname{six}^{6}$. In this way, we can see whether district-level political factors influence (with some lags) the likelihood that children who have supposedly just started first grade will go on to complete their primary education. Given this procedure for merging the two datasets and since the women's political representation variables are constructed as a three-year average (Section 3.4.2), our final

\footnotetext{
${ }^{4}$ The database is available at: http://www .aeaweb.org/articles.php?doi=10.1257/app.4.1.212.

${ }^{5}$ Creating district codes was very time-consuming as the district boundaries changed over time: only between 2001 and 2011 34 districts of our sample changed boundaries. While it was possible to follow the districts that split or changed name during this period, information on those districts that were created later combining parts of existing districts was lost. This is why the number of districts used in the main estimates of this paper is slightly lower than those used by Clots-Figueras (2012)) (219 vs. 233)

${ }^{6}$ While Clots-Figueras used the 1999-2000 NSSO dataset, which includes information on rural-urban migration, the 20112012 NSSO survey does not contain such information. Therefore, we were unable to restrict the sample to people who did not migrate to a different district. However, the evidence points to a limited migration between districts in the period under review (Topalova, 2010; Munshi and Rosenzweig, 2009). Other studies make the same assumption (Edmonds et al., 2010)
} 
dataset covers the period 1970-2003, while Clots-Figueras' main analysis is based on data only for the period 1970-1992. Focusing on these additional 11 years is very important because since 1993 many state governments introduced the "Discretionary Constituency Fund" to incentivize the legislator to engage more in district specific issues.

Finally, in order to explore potential channels through which the relationship between women's political representation and educational outcomes operates, we merged the NSSO database with three other small databases we constructed. The first database includes census data on the presence of schools in villages in the district in certain years, i.e. 1971, 1981, 1991, and, 2001. The second database is taken from the Centre for Monitoring Indian Economy (CMIE) and includes information on the number of schools per 100,000 inhabitants. This information has been collected every five years since 1980 .

The third database contains data on the beneficiaries of the MDM scheme, aggregating individual-level data from NSSO at district level. Given that the programme was launched only in the second half of 1990s and data are available only from 1999, we decided to extend the analysis to the period after the one used for the main quantitative analysis. Precisely, our data cover the period between 1999 and 2011, with the exclusion of 2010 when no NSSO survey was conducted. This implied also extending the political dataset until 2011: for this purpose we generated our indicators based on the database recently created by Bhavnani (2014). While this analysis cannot specifically identify the relevance of this channel, it can definitely provide information on whether, more in general, women in politics pay more attention to the implementation of social and educational programmes like the MDM and eventually target more girls.

\subsubsection{Variables}

The dependent variable of the main specification is a dummy variable indicating whether the individual has completed primary education. Table 3.1 shows the descriptive statistics for all variables: although about $66 \%$ of children have completed primary education, there is considerable variation in time and across districts ${ }^{7}$. There is a clear positive trend in primary school completion (Figure 1), which is in line with the aggregate figures reported by the Ministry of Education.

\footnotetext{
${ }^{7}$ The number of observations used in this study is lower than that used in Clots-Figueras' one though here we cover 11 more years. This is because the 1999-2000 NSSO survey has larger sample size than the 2011-2012 survey: in the 16 states here examined the population aged 14 or above in the former survey was nearly 500,000 against nearly 275,000 in the later.
} 
Table 3.1: Descriptive statistics

\begin{tabular}{|c|c|c|c|c|}
\hline INDIVIDUAL VARIABLES & Mean & SD & Observations & Source \\
\hline Primary education or higher & 0.66 & 0.48 & 96037 & NSSO \\
\hline Female & 0.49 & 0.50 & 96037 & NSSO \\
\hline Urban & 0.29 & 0.45 & 96037 & NSSO \\
\hline Scheduled Caste & 0.20 & 0.40 & 96037 & NSSO \\
\hline Scheduled Tribe & 0.08 & 0.27 & 96037 & NSSO \\
\hline Other Backward Caste & 0.70 & 0.46 & 96037 & NSSO \\
\hline Hindu & 0.83 & 0.38 & 96037 & NSSO \\
\hline Islamic & 0.13 & 0.33 & 96037 & NSSO \\
\hline Christian & 0.01 & 0.11 & 96037 & NSSO \\
\hline Other religions & 0.03 & 0.18 & 96037 & NSSO \\
\hline DISTRICT VARIABLES (main models) & Mean & SD & Observations & Source \\
\hline $\begin{array}{l}\text { Share of constituencies won by women: previ- } \\
\text { ous } 3 \text {-year average }\end{array}$ & 0.038 & 0.07 & 7111 & Pol. database \\
\hline $\begin{array}{l}\text { Share of constituencies won by women in close } \\
\mathrm{m} \text {-f contests }(2.5 \% \text { margin }) \text { : previous } 3 \text {-year av- } \\
\text { erage }\end{array}$ & 0.004 & 0.02 & 7111 & Pol. database \\
\hline $\begin{array}{l}\text { Share of constituencies won in close } \mathrm{m}-\mathrm{f} \text { con- } \\
\text { tests }(2.5 \% \text { margin): previous } 3 \text {-year average }\end{array}$ & 0.007 & 0.03 & 7111 & Pol. database \\
\hline $\begin{array}{l}\text { Share of constituencies reserved for } \mathrm{SC} / \mathrm{ST} \\
\text { members (previous } 3 \text {-year average) }\end{array}$ & 0.254 & 0.18 & 7111 & Pol. database \\
\hline Female proportion of population & 0.482 & 0.01 & 7111 & Census \\
\hline Literacy rate: male (previous 3 -year average) & 0.532 & 0.16 & 7111 & Census \\
\hline Literacy rate: female (previous 3-year average) & 0.283 & 0.17 & 7111 & Census \\
\hline DISTRICT VARIABLES (channels) & Mean & SD & Observations & Source \\
\hline $\begin{array}{l}\text { Proportion of villages with at least one primary } \\
\text { school }\end{array}$ & 0.76 & 0.19 & 1101 & CENSUS \\
\hline $\begin{array}{l}\text { Proportion of villages with at least one middle } \\
\text { school }\end{array}$ & 0.24 & 0.21 & 1067 & CENSUS \\
\hline Primary schools per 100,00 inhabitants & 76.90 & 34.06 & 850 & CMIE \\
\hline Middle \& High schools per 100,000 inh. & 18.35 & 12.03 & 726 & CMIE \\
\hline $\begin{array}{l}\text { Mean number of MDMs per month (children } \\
6-10 \text { ) }\end{array}$ & 4.91 & 5.19 & 1893 & NSSO \\
\hline $\begin{array}{l}\text { Percentage of children aged 6-10 having one } \\
\text { MDMs per week }\end{array}$ & 24.32 & 25.03 & 1893 & NSSO \\
\hline $\begin{array}{l}\text { Percentage of children aged } 6-10 \text { having three } \\
\text { MDMs per week }\end{array}$ & 21.88 & 23.34 & 1893 & NSSO \\
\hline $\begin{array}{l}\text { Percentage of children aged } 6-10 \text { having four } \\
\text { MDMs per week }\end{array}$ & 19.65 & 21.88 & 1893 & NSSO \\
\hline
\end{tabular}


Figure 3.1: Trends in people's probability to complete primary education

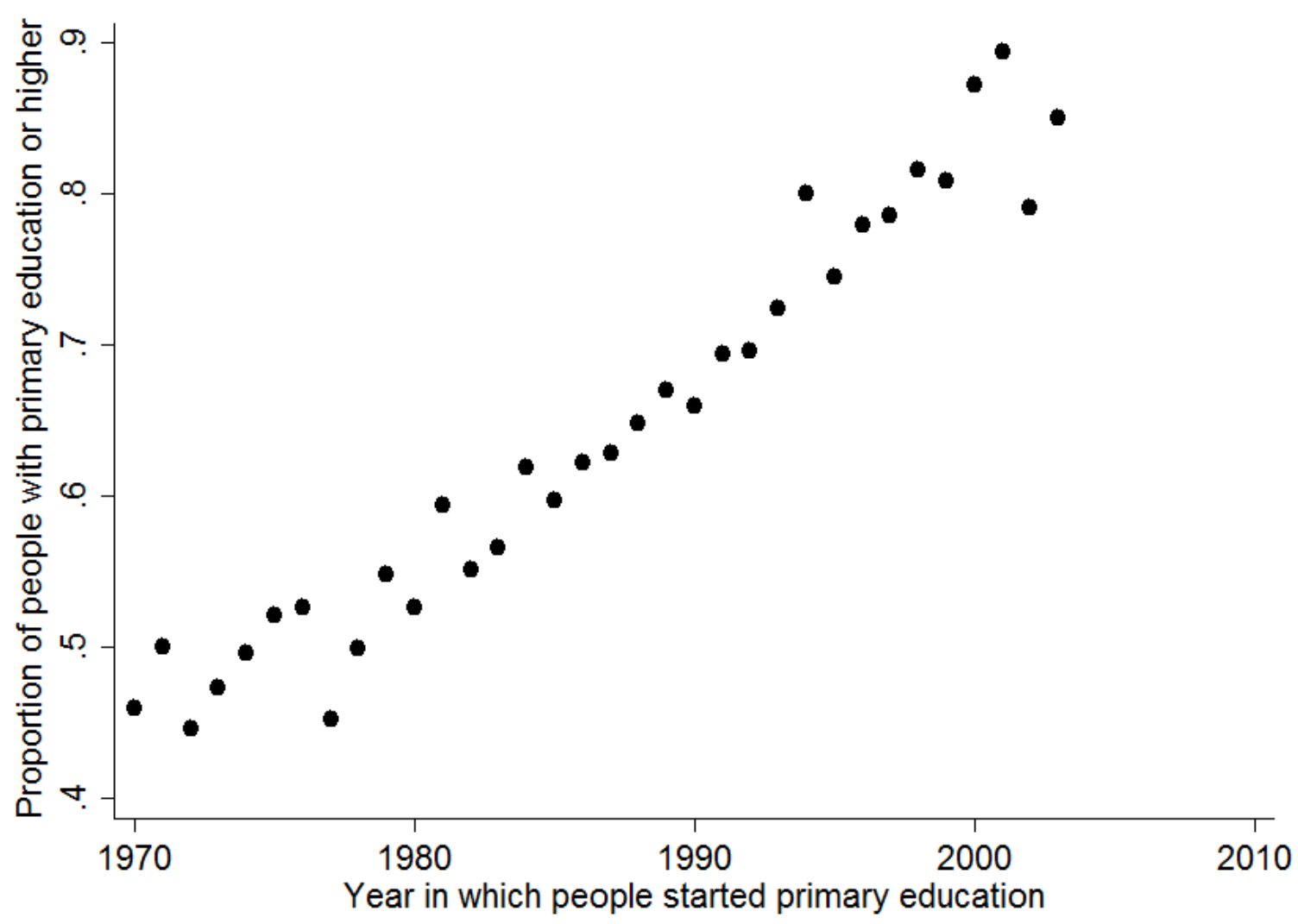

Source: our elaborations on NSSO data

Other individual-level covariates include sex and religion, whether the individual lives in an urban or rural area, and whether he/she belongs to a Scheduled Caste (SC) or a Scheduled Tribe (ST) or to another officially recognized backward caste. ${ }^{8}$

The central district-level variable is the female share of seats, calculated as a three-year average. At a detailed level, we connect information on each individual's completion of primary education with information on the political structure of the district in the three years before he/she started school. Our assumption is that the local political structure may affect educational achievements through investment choices, which means that it is a lagged effect. Moreover, using an average results in a more stable indicator. On average, women's representation is very low, at nearly $4 \%$. The standard deviation is high, suggesting large differences across districts.

\footnotetext{
${ }^{8}$ SCs and STs are communities who have suffered socio-economic deprivation due to discriminatory practices. They are protected under articles 341 and 342 of the Indian Constitution.
} 
There could be other, time-variant district determinants of primary school completion. As these could also be gender-differentiated we controlled in particular for male and female literacy rates, in addition to the female proportion of the population. As Table 3.1 makes clear, the male literacy rate $(53 \%)$ is almost double the female literacy rate $(28 \%)$. These data are taken from the Indian census and have been interpolated for the period between two censuses. Moreover, there are other variables reflecting the district political environment, which may have substantial effects on educational outcomes. Among them, particularly important is the share of constituencies held by SC/ST members. Given that some constituencies were by law reserved to SC/ST members throughout the whole period analysed, mostly based on the SC/ST population share at district level, controlling for the share of constituencies held by SC/ST members allows indirectly to control for SC/ST district population share, too. This is because there are not many cases in which SC/ST candidates won in non-reserved constituencies. ${ }^{9}$ Like for women's representation, also SC/ST representation is measured with an average for the three years before an individual started primary school.

In order to analyze the channels through which women's representation affects education, we used:

(a) four variables relating to school buildings. We obtained data from the national census on the proportion of villages with one primary school and the proportion of villages with one middle school in the district. Data on the number of primary schools and the number of middle or higher schools per 100,000 inhabitants were obtained from the CMIE;

(b) four different indicators of MDM coverage, namely the mean number of free meals taken by $6-10$ year-old children ${ }^{10}$ in school and the percentage of the latter taking at least one, three or four meals a week. ${ }^{11}$ These figures were calculated by aggregating data from NSSO surveys at district level. Nearly $24 \%$ of school-age children took at least one meal a week, with around $19 \%$ taking four meals a week. However, the mean monthly number of meals is very low. This is because the scheme was not adopted in many districts, particularly during the first few years.

While the channels variables (a) have been used also in the study of Clots-Figueras (2012), the variables related to the MDM management have not been so far utilized in association

\footnotetext{
${ }^{9}$ Our data show that the Pearson correlation between SC/ST population share and the share of constituencies held by SC/ST members is at least 0.85 for every year.

${ }^{10}$ The question in the NSSO surveys refers to 'free meals' in general and not specifically to the MDM scheme. While in some cases children were entitled to school meals under a local program, in the vast majority of cases in 1999-2011, these were provided under the official MDM scheme.

${ }^{11}$ Unfortunately, we do not know whether children are enrolled in school, which means that this indicator underestimates MDM coverage.
} 
with the district political variables.

\subsubsection{Estimation strategy}

The correlation between district characteristics, the likely presence of female politicians, and educational outcomes is the main concern of our main econometric analysis. More progressive districts are more likely to register high levels of female political representation and educational attainments at the same time, therefore generating an 'omitted variables bias'.

In order to alleviate this bias, we examined the recent literature on electoral models and employed instrumental variable regression: the share of constituencies won by women in a district was instrumented by the share of constituencies won by women in close contests with men (Bhalotra and Clots-Figueras, 2014; Clots-Figueras, 2012; Lee, 2008). Close contests are defined as elections in which a man beats a woman (as the runner-up) or vice versa by a relatively small margin, set here at $2.5 \%{ }^{12}$. In these cases, the result of the election will depend more on random factors. In other words, a female victory in a close contest cannot be interpreted as an indicator of a female-friendly electorate.

However, the presence of a close male-female contest is not random. In accordance with the estimation strategy used in other studies focusing on Indian districts (Bhalotra and ClotsFigueras, 2014; Clots-Figueras, 2012) in both the first and second stages, we controlled for the existence of close male-female contests in the district. The descriptive statistics of these two variables are reported in Table 3.1.

In all models we used district-fixed effects to account for time-invariant district-specific factors. Age-fixed effects were used for age-specific unobservable factors. As robustness check we also included state-specific linear time trends and district-specific linear time trends.

\subsection{Findings}

\subsubsection{From politics to educational outcomes}

Is a larger proportion of female politicians associated with better educational performance? The results obtained by using the different models are shown in Table 3.2.

\footnotetext{
${ }^{12}$ This choice is motivated as follows: the narrower the margin, the more reliable is the hypothesis of a random electoral outcome. As only those indicators with a $2.5 \%$ or $3.5 \%$ margin passed all the IV tests, we opted for the first option.
} 
The (biased) OLS estimates are reported in the first column, while all the following estimates are obtained with an IV approach. As expected, the coefficient of the endogenous variable is lower using the OLS model. Moreover, all the statistical tests show that the instrumental variable approach used in this paper works well: the share of constituencies won by women in close male-female contests (our IV) is highly correlated with women's political representation (our endogenous variable; see Table 3.3b). Moreover, the IV is not weak, as confirmed by the Anderson-Rubin Wald test (Table 3.3a). For this reason, only the IV estimates were interpreted.

Model 2 shown in Table 3.2 includes individual controls as well as district-fixed and agefixed effects. Women's political representation has a clear positive influence on the likelihood of children completing primary education, though the coefficient is significant only at the 0.17 level.

Table 3.2: Effect of women's political representation on primary education completion

\begin{tabular}{|c|c|c|c|c|c|}
\hline & (1) & $(2)$ & $(3)$ & (4) & (5) \\
\hline & OLS & IV & $\begin{array}{l}\text { IV with dis- } \\
\text { trict controls }\end{array}$ & $\begin{array}{l}\text { IV with state } \\
\text { time trends }\end{array}$ & $\begin{array}{l}\text { IV with dis- } \\
\text { trict time } \\
\text { trends }\end{array}$ \\
\hline \multirow{2}{*}{$\begin{array}{l}\text { Share of constituencies } \\
\text { won by women }\end{array}$} & -0.025 & 0.480 & $0.602^{*}$ & $0.557^{*}$ & $0.525^{*}$ \\
\hline & $(0.060)$ & $(0.343)$ & $(0.367)$ & $(0.338)$ & $(0.277)$ \\
\hline \multirow{2}{*}{$\begin{array}{l}\text { Share of constituencies } \\
\text { won in close } m-f \text { contests }\end{array}$} & & $-0.401^{* *}$ & $-0.474^{* *}$ & $-0.445^{* *}$ & -0.241 \\
\hline & & $(0.198)$ & $(0.222)$ & $(0.207)$ & $(0.168)$ \\
\hline Individual controls & $\mathrm{X}$ & $\mathrm{X}$ & $\mathrm{X}$ & $\mathrm{X}$ & $\mathrm{X}$ \\
\hline District controls & NO & NO & $\mathrm{X}$ & $\mathrm{X}$ & $\mathrm{X}$ \\
\hline District fixed effects & $\mathrm{X}$ & $\mathrm{X}$ & $\mathrm{X}$ & $\mathrm{X}$ & $\mathrm{X}$ \\
\hline Age fixed effects & $\mathrm{X}$ & $\mathrm{X}$ & $\mathrm{X}$ & $\mathrm{X}$ & $\mathrm{X}$ \\
\hline State-specific time trends & NO & NO & NO & $\mathrm{X}$ & $\mathrm{NO}$ \\
\hline District-specific time trends & NO & NO & NO & NO & $\mathrm{X}$ \\
\hline $\mathrm{N}$ & 96037 & 96037 & 96037 & 96037 & 96037 \\
\hline adj. R2 & 0.258 & 0.255 & 0.255 & 0.259 & 0.267 \\
\hline
\end{tabular}

Source: our elaboration on data from NSSO survey 2011-2012 and Clots-Figueras (2012) political data Standard errors clustered at district level in parentheses

All estimates were carried out with age- and district-fixed effects

${ }^{*} \mathrm{p}<0.10,{ }^{* *} \mathrm{p}<0.05,{ }^{* * *} \mathrm{p}<0.01$ 
Table 3.3a: Tests for the validity of the instrumental variables

\begin{tabular}{lcc}
\hline Test & Statistics & P-value \\
\hline $\begin{array}{l}\text { Correlation IV - endogenous variable } \\
\text { Shea Partial R2 (from the first stage) }\end{array}$ & 11.09 & 0.001 \\
Underidentification tests & & \\
Kleibergen-Paap rk LM statistic & Chi-sq $(1)=10.57$ & 0.001 \\
Kleibergen-Paap rk Wald statistic & Chi-sq $(1)=11.09$ & 0.001 \\
Weak identification test & & \\
Anderson-Rubin Wald test & $\mathrm{F}(1,218)=2.32$ & 0.13 \\
\hline
\end{tabular}

$\mathrm{IV}=$ Share of constituencies won by women in close male-female contests.

Endogenous variable $=$ Share of constituencies won by women.

Table 3.3b: First stage of the instrumental variable estimates (Table 3.2 column (2))

\begin{tabular}{lc}
\hline & $\begin{array}{c}\text { Share of constituencies } \\
\text { won by women }\end{array}$ \\
\hline Scheduled Tribe or Scheduled Caste & -0.001 \\
Other backward caste & $0.001)$ \\
& 0.000 \\
Female & $(0.001)$ \\
& 0.000 \\
Urban & $(0.000)$ \\
Hindu & $0.001^{* *}$ \\
& $(0.001)$ \\
Islamic & 0.000 \\
Christian & $(0.001)$ \\
Share of constituencies won in close m-f con- & -0.001 \\
tests & $(0.002)$ \\
Share of constituencies won by women in & $-0.006^{*}$ \\
close m-f contests & $(0.003)$ \\
& 0.052 \\
Constant & \\
\hline & $(0.211)$ \\
& $0.788^{* * *}$ \\
& \\
& $(0.237)$ \\
& $(\mathbf{0 . 2 3 7})$ \\
& 0.001 \\
& $(0.005)$ \\
\hline
\end{tabular}

Standard errors clustered at district level in parentheses

${ }^{*} \mathrm{p}<0.10,{ }^{* *} \mathrm{p}<0.05,{ }^{* * *} \mathrm{p}<0.01$ 
In the third model, female and male literacy rates, the female proportion of the population and the SC/ST share of the population are added to account for other possible district-level characteristics that may influence educational outcomes. The effect of the proportion of district seats won by women is now significant, at the 0.10 level. This means that children living in districts with a higher female representation are significantly more likely to complete primary education. The size of the coefficient implies that, by increasing women's political representation at district level by 10 percentage points, the probability of an individual completing primary education will rise by nearly 6 percentage points. This is about $9 \%$ of the total probability that an individual has to complete primary education. These results are also robust to the inclusion of state-specific linear time trends (column 4, Table 3.2) and district-specific linear time trends (column 5, Table 3.2).

As we also controlled for the SC/ST proportion of the district population, this is the exclusive effect of the politicians' gender, beyond the caste effect. These results differ from those obtained in the key reference paper for this study, the one carried out by Clots-Figueras (2012) with older data: she, in fact, did not find a significant effect on the whole Indian sample.

There are substantial differences between urban and rural areas in India in terms of infrastructure and standards of living. Only in recent years have the government and the private sector tried to improve the state of the infrastructure in rural areas, thus narrowing the gap with urban areas. For the above reasons, we performed separate estimates for the two areas (Table 3.4).

The effect of women's political political representation is positive in both the cases. However, in contrast with Clots-Figueras' (2012) results, we found a larger, though not statistically significant, effect in rural areas. This might be due to lower average levels of education in the latter areas. 
Table 3.4: Effect of women's political representation on primary education completion: disaggregated results

\begin{tabular}{lcccc}
\hline & $(1)$ & $(2)$ & $(3)$ & $(4)$ \\
& IV Urban & IV Rural & IV Female & IV Male \\
\hline Share of constituencies won by women & 0.259 & 0.627 & $1.087^{*}$ & 0.081 \\
& $(0.319)$ & $(0.431)$ & $(0.642)$ & $(0.315)$ \\
Share of constituencies won in close m-f & -0.046 & $-0.609^{* *}$ & -0.670 & $-0.305^{*}$ \\
contests & & & & \\
& $(0.206)$ & $(0.272)$ & $(0.419)$ & $(0.182)$ \\
Individual-level control variables & $\mathrm{X}$ & $\mathrm{X}$ & $\mathrm{X}$ & $\mathrm{X}$ \\
District-level control variables & $\mathrm{X}$ & $\mathrm{X}$ & $\mathrm{X}$ & $\mathrm{X}$ \\
District fixed effects & $\mathrm{X}$ & $\mathrm{X}$ & $\mathrm{X}$ & $\mathrm{X}$ \\
Age fixed effects & $\mathrm{X}$ & $\mathrm{X}$ & $\mathrm{X}$ & $\mathrm{X}$ \\
\hline$N$ & 37818 & 58219 & 47802 & 48235 \\
adj. R2 & 0.187 & 0.263 & 0.295 & 0.185 \\
\hline
\end{tabular}

Source: our elaboration on data from NSSO survey 2011-2012 and Clots-Figueras (2012) political data

Standard errors clustered at district level in parentheses

All estimates were carried out with age- and district-fixed effects

${ }^{*} \mathrm{p}<0.10,{ }^{* *} \mathrm{p}<0.05,{ }^{* * *} \mathrm{p}<0.01$

The above results provide evidence of the validity of the citizen-candidate model of political economy, given that a politician's identity plays an important role in relation to education. Moreover, the findings appear to confirm that women pay more attention to education than men. We then decided to test another hypothesis from the literature: are women more interested in girls' education? In order to answer this question, we disaggregated the analysis by gender.

Columns (3) and (4) in Table 3.4 show the results for the female and male sample respectively. The difference is striking: female representation has a positive and significant effect on the probability of girls completing primary education, while the effect is largely insignificant for boys. Given the magnitude of the coefficient, we may conclude that, on average, an increase in female representation by 10 percentage points raises the likelihood of girls completing the full cycle of primary school by almost 11 percentage points. This corresponds to nearly $18 \%$ of the overall girls' probability to complete primary education. This seems to suggest that politicians do have a special concern for children of the same gender or, at least, for the most vulnerable segments of society, which in this case happen to be girls. 


\subsubsection{From politics to educational inputs}

The previous subsection revealed a positive correlation between the number of female politicians and educational outcomes. But how does this relationship operate? What are the channels? The following sections analyze two sets of pathways: school construction and MDM coverage.

Table 3.5: Effect of women's political representation on educational infrastructures

\begin{tabular}{|c|c|c|c|c|}
\hline & \multicolumn{2}{|c|}{$\begin{array}{l}\text { Prop. of villages with a school } \\
\text { in the district }{ }^{\mathrm{a}}\end{array}$} & \multicolumn{2}{|c|}{ inhabitants $^{\mathrm{b}}$} \\
\hline & (1) & (2) & (3) & (4) \\
\hline & Primary & Middle & Primary & Secondary/higher \\
\hline \multirow{2}{*}{$\begin{array}{l}\text { Share of constituencies won } \\
\text { by women }\end{array}$} & 0.438 & 0.087 & 25.592 & -11.916 \\
\hline & $(0.420)$ & $(0.327)$ & $-(60.512)$ & $(8.767)$ \\
\hline \multirow{2}{*}{$\begin{array}{l}\text { Share of constituencies in } \\
\text { close } \mathrm{m}-\mathrm{f} \text { contests }\end{array}$} & -0.002 & -0.051 & -20.272 & 6.754 \\
\hline & $(0.178)$ & $(0.152)$ & $(36.595)$ & $-(4.544)$ \\
\hline $\begin{array}{l}\text { District-level control vari- } \\
\text { ables }\end{array}$ & $\mathrm{X}$ & $\mathrm{X}$ & $\mathrm{X}$ & $\mathrm{X}$ \\
\hline District fixed effects & $\mathrm{X}$ & $\mathrm{X}$ & $\mathrm{X}$ & $\mathrm{X}$ \\
\hline Age fixed effects & $\mathrm{X}$ & $\mathrm{X}$ & $\mathrm{X}$ & $\mathrm{X}$ \\
\hline$N$ & 889 & 859 & 850 & 726 \\
\hline adj. R2 & 0.857 & 0.899 & 0.822 & 0.955 \\
\hline
\end{tabular}

Source: our elaboration on data from Indian census, CMIE and Clots-Figueras (2012) political data Standard errors clustered at district level in parentheses

${ }^{*} \mathrm{p}<0.10,{ }^{* *} \mathrm{p}<0.05,{ }^{* * *} \mathrm{p}<0.01$

a Source: Indian census; b Source: CMIE.

The first part of Table 3.5 shows the estimates of the effect of women's political representation on the proportion of villages with a school in the district. The coefficients are always positive, but far larger for primary schools. This would suggest that women politicians are particularly interested in very basic education. However, the effects are insignificant, at the 0.10 level. The models with the number of primary and secondary/higher schools per 100,000 inhabitants as dependent variables produce similar results. The proportion of district seats won by women is not a significant explanatory variable: in the latter case, its coefficient is actually negative. 


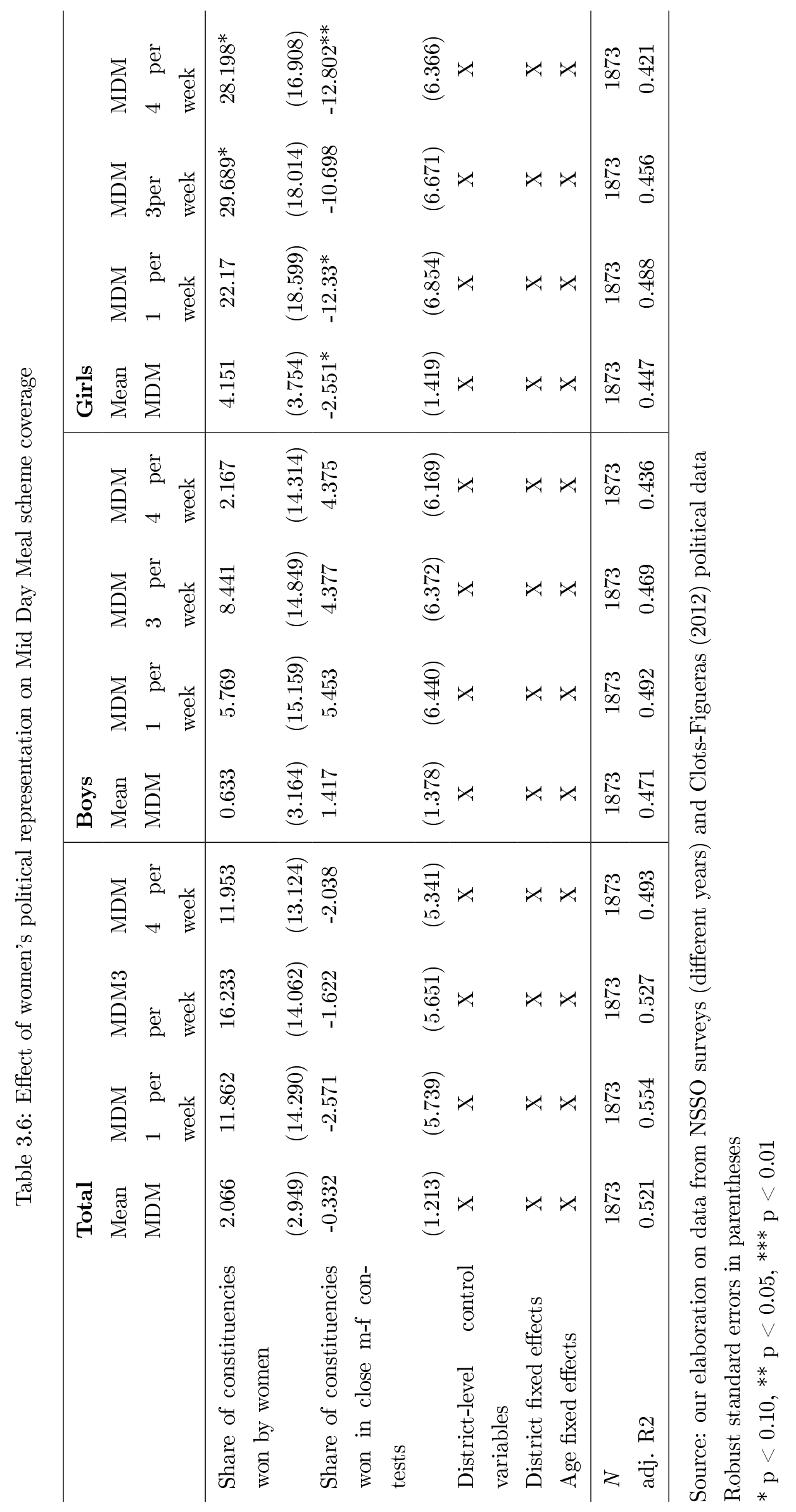


The MDM scheme is a highly important social welfare program in India. For this reason, we would expect politicians paying more attention to children's education and nutrition to invest in the program and manage it better. As the MDM is relatively new and as efforts to make the budget allocation more transparent were not made until recently, we only have data concerning its coverage. Our analysis shows that there is positive but insignificant correlation between female political representation and MDM coverage (Table 3.6). Once we disaggregate the MDM coverage by gender, we notice positive and significant effects of women's political representation for two of the four indicators examined. Therefore, this analysis provides some, though limited, evidence of a particular interest of female politicians towards educational programmes like the MDM. In conclusion, we investigated some possible channels and found that only those related to the implementation of the MDM and its specific gender-related targeting help, to some extent, to explain the findings in the main estimates. There are two possible explanations for this result. The first is that we did not have adequate data to consider the most important pathways. In particular, the following weaknesses must be acknowledged: 1. Decisions taken by state assemblies are more important than those taken at state assembly constituency level in terms of the budget allocated to different aspects of education. 2. States also decide whether and when to join the MDM scheme. There is thus limited room for MLAs to affect MDM coverage. MLAs play a more important role in the management of the scheme. For example, it would be interesting to see whether districts with a larger number of female MLAs stick more closely to the national guidelines for the MDM scheme. These include a more participatory approach, a more transparent management of funds, and respecting the nutritional contents of the meals. However, no data are currently available on these practices. 3. We were not able to take account of other relevant channels, such as those relating to school quality. The second interpretation is that higher levels of representation of women can ensure higher educational levels - especially for women - via a demonstration effect. Women in office can become role models for other women, raising their educational aspirations and therefore improving their attainments, without necessarily pushing forward general education policies. Empirical evidence of this "role model" effect is found in India (Beaman et al., 2012) as well as in other countries (Powley, 2007). 


\subsection{Conclusions}

This paper has a threefold objective: (1) to analyze whether politicians' gender has a bearing on the educational achievements of the residents of the districts in which they were elected; (2) to understand whether politicians are more sensitive to the needs of people of the same gender; (3) to explore the possible channels through which these relationships work. By applying an instrumental variable approach to a dataset obtained by merging individual data with political variables for Indian districts, we show that women's political representation has a substantial effect on the probability of children completing primary education. An increase in women's political representation at district level by 10 percentage points can produce a rise of nearly 6 percentage points in the likelihood of an individual completing the full cycle of primary education. The study of Clots-Figueras (2012)), from which we took the identification strategy, pointed only on the importance of women's political representation in urban areas.

A disaggregated analysis reveals that women's political representation raises the educational achievements of girls significantly more than that of boys. This is a completely novel result, as this aspect had never been examined in previous works. Finally, we investigated two possible macro-channels through which women's political representation might affect educational outcomes, i.e. the presence of school buildings and the coverage of the MDM scheme. Our results show that the first channel does not help to explain the relationship. In contrast, we detect a positive, though insignificant, effect of women's political representation on the MDM coverage and, above all, some positive and significant evidence for the sample of girls. This suggests that female politicians may be particularly interested in girls' education.

Overall, the paper provides initial evidence of the contribution of female political representation on educational attainments especially among girls. This occurs partly through the improvement of their access to educational and welfare programs like the MDM, while an increase of school infrastructures does not appear as an important mediating factor. However, an in-depth understanding of the comprehensive pathways through which women's representation in politics impacts on children's education requires further research. Our analysis, in fact, cannot test other important channels and cannot rely on frequent, high-quality data. Provided these limitations, our findings are compatible with existing literature that points to the "role model" effect. According to this explanation, the presence of women in important

political roles itself helps girls and women challenge prevalent stereotypes and increase their aspirations, including educational aspirations. Though we cannot test it empirically, the role model is likely to play an important role in explaining our findings. 
This paper engages in a broader debate on the effects of women's political representation. Section 3.2 reviews the existing literature in India, which shows that female political representation is associated with lower poverty levels in several dimensions, though the evidence is not always clear. Moreover, one could argue that female political representation is beneficial to democracy as it forms the basis for a more pluralistic political life, given that more 'voices' can be heard. As Sen argues $(2005,240)$, an increase in women's (political) agency boosts 'the freedom to question established values and traditional priorities'. This paper shows that it can also be important in raising educational levels in a country characterized by wide educational inequalities and, as a consequence, in enhancing women's empowerment.

This means that multiple policy objectives could be met with one policy tool. However, caution needs to be exercised in adopting quick fixes such as gender quotas. The, 20-year experience with female political reservation in Indian Gram panchayats (Kalaramadam, 2018) and the experience of a neighbouring country like Bangladesh (Panday, 2008) show that enhancing women's substantial role in the political arena cannot be achieved simply by waving the magic wand of gender quotas. Female political reservation can help women to be heard, but it has to be integrated with multiple interventions aimed at diminishing gender gaps in terms of education, employment opportunities and access to key assets (Doss et al., 2012). Otherwise, there is a serious risk that women with little experience and low levels of education will occupy seats in state assemblies, where they can be manipulated by male politicians. Another risk is that only women from economic and political elites will be elected, thus exacerbating the discrimination suffered by women from the lowest classes. All these issues have been under debate in India since a few years, with the approval of The Women's Reservation Bill, which aims to reserve one third of the seats in the Lower House and the state assemblies for women, by the Upper House in March 2010. However, given that the Lower House never voted on it, the Bill lapsed in 2014. 


\title{
Chapter 4
}

\section{Political Reservation for Scheduled}

\section{Castes and Business Exclusion:}

\section{Examining Political Quotas' Effects on}

\section{Private Sector Entrepreneurship,1990 to $2007^{1}$}

\begin{abstract}
This study examines the preferences of political leaders elected through the Scheduled Castes (SC) electoral quotas. For this purpose, this paper focuses on the preferences of SC politicians in state assemblies on business outcomes in their constituency. The study chooses possible business outcomes in the private non-agricultural sectors that directly affect the welfare of the Scheduled Castes and the other castes. These include: entrepreneurship; entrepreneurs' access to public goods; entrepreneurs' dependence on family labor; sectoral mobility; employment of SC in other caste enterprises; SC entrepreneurs' ability to hire workers from other castes and patronage. The study covers the 15 largest Indian states during the period between 1990 and 2007. It finds that SC leaders do not promote inclusion of SC members in the private sector businesses and do not affect the overall business outcomes of the other castes. However, this study finds that SC leaders are involved in patronage in the rent-seeking sectors.
\end{abstract}

Key words: Scheduled Castes, Private Sector. JEL code: J20, J23, I10

\footnotetext{
${ }^{1}$ The paper was presented at the Development Economics Seminar, University of Göttingen. I thank all the participants of the seminar for their valuable comments. My sincere thanks to Prof. Klasen for providing a detailed comment in shaping the paper. I am thankful to Prof. David Blakeslee and Prof. Ritam Chaurey for their guidance and help. The usual disclaimer applies.
} 


\subsection{Introduction}

A growing literature has examined the preference of Indian politicians (Lehne et al., 2018; Jensenius, 2015; Asher and Novosad, 2017). These studies focus on the preference of members of legislative assemblies in their constituency. Given that, members of legislative assemblies (MLAs) have dual functions, passing laws at the state assemblies and dealing with constituency demands. The reason recent studies focus on the preference in the constituency is that members of legislative assemblies spend more time on constituency works than on their legislative role (Jensenius, 2015; Jensenius and Suryanarayan, 2015; Chopra, 1996). Political reform also supports leaders to focus on issues in the constituency. Since the early 1990s, MLAs have had access to discretionary development funds through the Member of Legislative Assembly Constituency Development Scheme to fix their constituency specific issues. In addition to that, in the topics related to constituency, leaders may have discretion on the selection of beneficiaries and commissioning projects.

Jensenius (2015) is the first study that examines the preference of Scheduled Caste leaders in the Indian state assemblies at a constituency level. This study finds that these leaders do not favor these castes in literacy and employment, nor do they affect the efficacy of the political system. Asher and Novosad (2017) find that members of legislative state assemblies favor entrepreneurs of their political party through the influence and business performance through the actions of government bureaucrats. Lehne et al. (2018) find that in the case of road projects, members of legislative assemblies use their influence to commission projects to contractors of their caste. Although Jensenius (2015) studies the SC politicians' preference, she mentions that not focusing on the outcomes relevant to politicians might be a limitation of her study. But the other two studies (Lehne et al., 2018; Asher and Novosad, 2017) suggest that business outcomes are relevant to the politicians.

The literature presents possible intentions and outcomes that arise due to the leaders' preferences. The previous literature argues that politicians hold public office for their private return, to serve their patrons, adversely affect the efficacy of the political system and they favor their castes to reduce the discrimination. The main research question that emerged from literature is whether or not Scheduled Castes members of legislative assemblies influence business outcomes in favor of their whole communities or only to their patrons. In this paper I extend Jensenius (2015) to look at the effect the effect of SC reservation on business outcomes. 
This paper finds that SC business presence in the rent-seeking business sectors, gas and water, are higher in the reserved constituencies than the unreserved counterfactual constituencies. Thus, it shows that they do influence the business outcomes in favor of their patrons. However, this paper finds that reservation for Scheduled Castes at state assemblies shows no support towards their castes in private sector businesses.

There are multiple reasons why Scheduled Castes politicians might not affect the SC entrepreneurs in their constituencies. Firstly, Scheduled Castes are historically not part of the business sector. Hence, Scheduled Caste leaders lack business experience, which may be a reason for not leading their communities into business. Secondly, the influence of established people in business in the political parties would stop any favoritism towards Scheduled Castes, in order to avoid business competition. Thirdly, to survive in the business, the Scheduled Castes might not experience a conducive environment, given other castes' attitudes or actions.

Apart from the reason that politicians could influence business outcomes, SC standing in the private sector also encourages the study of business outcomes. In the modern Indian economy, exclusion of Scheduled Castes in the private non-agriculture sector is a sign of failure in addressing caste discrimination. In 1991, India initiated several reforms to transform its national economy to an open one with a greater reliance on market forces (Ahluwalia, 2002). As a result, private non-agricultural sectors emerged as an engine of Indian economic growth. On the development aspects, critiques were raised by several researchers (Damodaran, 2008; Deshpande and Sharma, 2016; Iyer et al., 2013; Jodhka, 2010; Thorat and Sadana, 2009; Varshney, 2007, 2012) that the benefits of rapid economic growth from reforms in 1991 have not been shared equally among the different sections of society. The lower caste social group, the SC, are especially under-represented in the ownership of private non-agricultural enterprises (Iyer et al., 2013). Besides their weakness in entrepreneurship, SC members also have low employment rates in private enterprises. It is the case that entrepreneurs prefer to hire labor from their own caste (MSME, 2006-07). SC's low rates of employment and underrepresentation in entrepreneurship in private non-agricultural sectors signal continuing social exclusion in the fast-growing Indian economy. Consequently, SC leaders advocate for fairness and equal opportunity in the private sector (Nigam, 2002). Their collective demand focuses on affirmative legislative actions in favor of SC, such as job reservation in the formal private sector (Lerche, 2008).

Indian constitutional and theoretical models expect that SC politicians could lead as an agent of change in eliminating caste discrimination. The Indian constitution guarantees political representation of SCs in three spheres of government: central, state, and local bodies. 
This mandated political representation in governments is expected to bring policies in favor of their castes. Theoretical predictions are ambiguous about the preferences of politicians from underrepresented ethnic quotas. Traditional theoretical models (Downs, 1957; Arrow, 1951; Mayhew, 1974; Fenno and Fenno Jr, 1978; Kingdon, 1989; Cox and McCubbins, 2005) assume that politicians are likely to be vote-seeking or be interested in holding office in future elections as well. Highly political competition does not allow SC politicians to favor their castes, and SC politicians are more likely to follow the command of parties' high command. An alternate view, the citizen-candidate model (Osborne and Slivinski, 1996; Besley et al., 2004; Horowitz, 2001), predicts that politicians are assumed to act in favor of their ethnic group.

I use the Economic Census (EC) conducted in 1990, 1998, and 2005 and the 2006-07 Micro, Small and Medium Enterprises (MSME) census results. Both the censuses have details about the enterprise owners' caste, and report the location of the enterprises at the village level. The Economic Census covers all the non-agricultural enterprises in the country. I use the Economic Censuses to measure SC entrepreneurs' business positions in non-agriculture sectors. The MSME census covers both manufacturing and services enterprises. However, MSME does not cover manufacturing enterprises with an investment of more than 100 million Rupees in plant and machinery, and it also excludes service enterprises with an investment of more than Rs 50 million in equipment. Most of the business outcome variables are constructed using ECs. The MSME census provides detailed information about the caste of labor, information that is not available in the EC. The use of the MSME census is to measure the employment of SC members in other caste enterprises and SC entrepreneurs' ability to hire labor from upper castes.

Institution design in reserving the constituencies for SC allows selecting plausible counterfactuals constituencies for reserved constituencies. The Delimitation Commission of India is a high powered body in charge of choosing the reserved constituencies. The reserved constituencies are not selected randomly. To overcome the selection bias, Jensenius (2015) exploits features in the institution design and employs a matching method to pair each reserved constituency to a general constituency. I use the same counterfactual general constituencies selected by Jensenius (2015) as a control group for reserved constituencies. The empirical strategy estimates the effect of political reservation by comparing the differences in the business outcomes between the reserved and control constituencies. 


\subsection{Background on Caste, Politics, and Business}

Caste discrimination persists in the modern Indian economy. The Indian caste system historically prevents members of lower castes from using public goods and forces them to do low-profile jobs (Bob, 2007). In 2006, because of caste, SCs were not allowed to use selected public streets (Girard, 2018). Centuries of the caste-based social organisation have left a legacy of inequality in access to land, education, business ownership and occupation (Desai and Dubey, 2012). For example, wages are lower for SCs than for the upper castes. Lower castes have less business ownership in the non-agriculture sector. Iyer et al. (2013) show lower castes' under-representation in business, and that SC entrepreneurs have lower access to public goods. Lower caste people still face a higher incidence of poverty as compared to members of the upper castes (Panagariya and Mukim, 2014).

To intervene the caste discrimination, the Indian government classify the complex caste structure to a few groups. The Indian traditional caste system classifies people based on their occupational status, known as Jati, and most Hindu surnames refer to their Jati (Dunning and Nilekani, 2013). The Hindus inherit their Jati identity from parents, and Jati is endogamous (Olcott, 1944). The Indian constitution classifies traditional social divisions (Jati) into four official social groups, Scheduled Tribes (ST), Scheduled Castes (SC), Other Backward Castes (OBC), Backward Castes (BC), and socioeconomically progressed castes which do not have an official classification name. The constitution caste classification is primarily used in various government programs and to carry out affirmative actions for lower castes.

Researchers show great interest in studying the effect of affirmation actions, especially several attempts in studying the impact of political representation. Since independence, political support for lower castes resulted in several affirmative action measures, including: quotas in public sectors jobs; higher education and political representation; and special protection status in the justice system. There are Indian constitutional guarantees for political representation of lower castes at three levels of governments: central, state and local. Political representation takes an essential place among the other affirmative actions, as political representation is meant to lobby new policy measures for lower castes. Several studies (Besley et al., 2004; Bardhan et al., 2010a; Chattopadhyay and Duflo, 2004a; Dunning and Nilekani, 2013; Chin and Prakash, 2011; Pande, 2003; Jensenius, 2015) have tested whether or not electoral quotas for lower castes erase the harmful discrimination in the society and induce favor toward lower castes. 
At the lowest level of, village, political representation, studies (Besley et al., 2004; Bardhan et al., 2010a; Chattopadhyay and Duflo, 2004a; Dunning and Nilekani, 2013) found that positive effect of electoral quotas on lower castes at the village level. SC pradhans (define) divert allocation of government welfare schemes towards SC households (Besley et al., 2004). In West Bengal, villages headed by $\mathrm{SC} / \mathrm{ST}$ pradhans tend to receive more benefits from local government and employment program benefits are redistributed towards SC/ST households (Bardhan et al., 2010a). SC pradhans invest a larger share of public goods in SC hamlets than do non-SC pradhans (Chattopadhyay and Duflo, 2004a). Political incentives of SC pradhans limit the distributive effects towards SC members (Dunning and Nilekani, 2013).

At the state level, SC's political representation, as an effect of electoral quotas, manifests via two channels, their legislative role and constituency work.

The earlier studies Chin and Prakash (2011); Pande (2003) have examined the legislative role. Pande (2003) finds that SC/ST politicians in the Indian state assemblies use their participation in legislative action to increase the welfare expenditure to $\mathrm{SC} / \mathrm{ST}$. The findings of Chin and Prakash (2011) show that SC MLA representation in state assemblies does not affect SC poverty, whereas reservation for STs helps to reduce their castes' poverty. They argue that political representation for lower castes does not guide what outcome the leaders may bring to their castes. Thus, the choice of favor is up to the leaders to decide. The empirical expectation of studies assumes that lower caste leaders favor their caste in the fields where lower castes have a low level of status.

In the MLAs workload share, constituency work has taken a considerable part. Political reform in India gives more resources and encouragement to MLAs to focus on constituency specific issues, with the legislative role declining. In the 1980s, the state government of Maharashtra allocated one million Rs to a discretionary fund for MLAs to spend on their local constituency (Blair, 2017; Oommen, 2010). In the late 1990s, many other state governments also followed Maharashtra's example and allocated discretionary funds to MLAs, known as the MLA Local Area Development Scheme Fund (MLALADS). MLAs' primary task is to represent their constituency in the state assembly. Chopra (1996) reports that only $3 \%$ of MLAs in the state assemblies consider their assembly work (passing legislative bills) as a primary duty. Jensenius and Suryanarayan (2015) find that time spent on legislative actions are also falling. The legislative actions are formed by the head of the political parties or MLAs holding a high position in the party. 
Studying the impact of constitution works is relatively recent as compared to the studies on the legislative role. Jensenius (2015) is the first attempt to look at the constituency-level effect of SC leader in state assemblies. Jensenius (2015) finds that the SC leader efficiency level is equal to that of other political leaders. The level of public goods available in the reserved constituencies is comparable to that of the general constituencies. Although her study attempts to look at the preference towards SC in education and employment, the author remarks that the limitation of the study is in not being able to look at various development outcomes relevant to the SC. Jensenius (2015) shows that the availability of public goods in reserved constituencies has not worsened, but whether the public goods in the reserved constituencies are shared equally with SC is not clear. This compels special attention, because the problem in sharing public goods with lower castes persist in some villages, as of 2006, SCs still face barriers even in accessing public streets (Girard, 2018).

Political reality urges an examination of whether SC politicians' actions favor patrons or all SC entrepreneurs. Most of the elected political leaders in India, have criminal charges against them (Dutta and Gupta, 2012; Aidt et al., 2011). Clientelism and vote buying practices are typical in India (Jeffrey, 2002; Wilkinson, 2006; Schneider, 2014). The criminal or corrupt candidates exploit voter tastes. The voters prefer immediate material benefits offered by the candidate over good governance, or they affiliate with the corrupt candidate to seek patronage, known as the patronage hypothesis (Banerjee et al., 2014). In developing and developed countries, there are several pieces of evidence to show that the politicians' exploitative behavior in the private sector supports their patrons. There are several ways they can help patrons: by protecting the corruptive business practices of patrons (Kurer, 1993); through the misuse the public money in the business of patrons (Robinson and Torvik, 2005); and helping to get opportunities for patrons in rent-seeking or monopolised businesses (Van Biezen and Kopecký, 2007). 


\subsection{Empirical Design and Data}

\subsubsection{Empirical Design}

The empirical strategy for identifying the effect of political reservation for SC is a matching method. To address the selection bias in the non-random assignment of reserved constituencies for SC in the state assemblies, I follow the empirical strategy applied by Jensenius (2015).

The Delimitation Commission is the high powered constitutional body responsible for drawing state assemblies' constituencies and selecting the reserved constituencies for SC. After independence, India constituted four Delimitation Commissions, in the years 1952, 1962, 1972 and 2002. The drawn boundaries of the first two commissions were revised in decennial. Since the third commission, the Indian government has frozen constituency boundaries for more than 30 years. The reason for the long period during which the constituencies' boundaries were frozen was to encourage family planning. The declaration of the third Delimitation Commission on constituency boundaries and reservation status was not altered between 19742007. The study period of this paper looks at the reservation effect during the reference years of the third Delimitation Commission.

The proportion of its SC population determines the allocation and number of reserved seats in a state and a district. The following two criteria for reserving constituencies for SC allow to select counterfactual constituencies:

(1) Reserved constituencies are ones where SC have high populations and (2) Reserved constituencies should be spatially dispersed, ie: two reserved constituencies should not be next to each other. It is well known that districts with large lower caste populations are the backward districts in India. Therefore, the selection is biased; reserved constituencies are not comparable to general constituencies.

Jensenius (2015) finds that step-wise selection process has resulted in slippage among many of the highest SC populated constituencies. That is, if a district is eligible for two reserved constituencies, the second highest SC population may not be chosen because of the second criteria, of not being contiguous to each other. The slipped constituencies with highly SC populated constituencies served as plausible counterfactuals. Out of 483 reserved constituencies, it was possible to get close counterfactual ones for 324 reserved constituencies. I limit my analysis to 317 pairs from the Jensenius (2015) list of 324 pairs of reserved and general constituencies. The average difference in the proportion of SC population (in the 
census for 1971) between the 317 pair of reserved and counterfactual constituencies is 1.6 percentage. In various indicators, such as SC literacy and employment, and public good access of SC, the 324 pairs are balanced in the pre-reservation period (as per Census 1971).

\subsubsection{Data}

The data for this paper were from the following sources: (1) Economic Census (EC); (2) Medium, Small and Micro Enterprises census (MSME); (3) Population Census; (4) online data of Jensenius (2015); and night light data from the Defense Meteorological Satellite Program Optical Linescan System (DMSP-OLS). I construct the night light data at the village level using ArcGIS tools. These censuses mentioned above provide location details at the village level. Village administrative boundaries are at a lower level than those of state assembly constituencies. Therefore, it is possible to construct the variables of interests from these censuses at the State assemblies' constituency level. I used the Economic Censuses conducted in the years 1990, 1998, and 2005 and constructed the village level panel data. The Economic Census of India is a complete enumeration of all establishments except those engaged in crop production and plantations; there is no minimum firm size, and both formal and informal establishments are included. The Economic Censuses provide detailed information on the location and industrial classification of each enterprise, the number of workers employed, the mix of family and hired labor, sources of finance, and the caste category of the enterprise owner.

I use the MSME census conducted in 2006-07 and exploit the enterprises' cross-section data. The MSME census covers most of the non-agricultural sector and excludes the large enterprises. The enterprises included in the MSME census account for $90 \%$ of employment in the non-agricultural sector. The advantage of the MSME census is that it provides information about the owners' castes and those of the workers employed.

EC and MSME census data have the advantage that they provide the basic facts about the business outcomes related to SC, as well as location details of the unit of the survey at the village level. However, one limitation of these censuses is that we do not have baseline information. The reservation boundaries are fixed for the period between 1974-2007 by the Delimitation Commission Act of 1972. I assume that pre-reservation period business outcomes are the same between the reserved and control constituencies. 
I use the 1991 Population Census to calculate the caste population at the village level. In addition to that, I use the village concordance directories from the Population Census for the years 1991 and 2001. One of the significant challenges is the merging of the EC census village names across 1990, 1998 and 2005. EC 1990 village codes are comparable to the Population Census 1991 and EC 2005 village codes are the same as in the Population Census 2001. Village concordance directories from population censuses helped merge the EC 1990 and EC 2005. However, EC 1998 village coding system follows neither the Population Census 1991 nor the Population Census 2001. Therefore, I used fuzzy matching algorithms to match the village name of EC 1998 with village name of Population census 2001.

I used shapefiles of state assembly constituencies and village geographic coordinates for population census 2001 to link the state assembly constituency to the village. Constituencies' pre-reservation period data, Population Census 1971, are taken from online data of Jensenius (2015). The primary data work in Jensenius (2015) are digitalizing village data from the 1971 Population Census report, merged with state assembly constituencies as drawn by the Delimitation Act of 1972, and merged with 1971 Population Census data and the 2001 Population Census.

Jensenius (2015) selects the counterfactuals general constituencies for 324 reserved constituencies by exploiting the institutional design used in picking the reserved constituencies. Using 1971 census variables, she shows that there is a balance of observable variables in the selected 324 pairs. I was able to get a link to the Economic Census data for 317 out of 324 pairs of reserved and general constituencies. I use village level data from the Economic Census. The number of villages falling within 319 pairs of reserved and general constituencies were 105,000. On an average, each state assembly has around 160 villages. 
Table 4.1: Summary Statistics

\begin{tabular}{|c|c|c|c|c|c|c|}
\hline & Year & Reserved & Control & Reserved & Control & $\begin{array}{l}\text { Reserved } \\
\text { minus } \\
\text { Control }^{1}\end{array}$ \\
\hline & & \multicolumn{2}{|c|}{ Mean } & \multicolumn{3}{|c|}{ No. of Villages } \\
\hline & & $(1)$ & $(2)$ & $(3)$ & $(4)$ & $(1)-(2)$ \\
\hline Share SC Population & 1971 & 24.77 & 23.46 & 53064 & 52638 & $\begin{array}{l}1.60^{* * *} \\
(0.22)\end{array}$ \\
\hline Entrepreneurship & & & & & & \\
\hline $\begin{array}{l}\text { Share of SC Enterprises in } \\
\text { a village }\end{array}$ & $\begin{array}{l}1990,1998 \\
\& 2005\end{array}$ & 10.29 & 9.98 & 140116 & 139432 & $\begin{array}{l}0.31 \\
(0.20)\end{array}$ \\
\hline$\%$ SC firms with only one & 1990,1998 & 67.37 & 67.06 & 62233 & 61085 & 0.31 \\
\hline $\begin{array}{l}\text { person } \\
\text { Average of employment in }\end{array}$ & $\begin{array}{l}\& 2005 \\
1990,1998\end{array}$ & 1.66 & 1.61 & 62233 & 61085 & $\begin{array}{l}(0.38) \\
0.06\end{array}$ \\
\hline $\mathrm{SC}$ firms & $\& 2005$ & & & & & $(0.06)$ \\
\hline Access to public service & & & & & & \\
\hline $\begin{array}{l}\% \text { SC firms with bank fi- } \\
\text { nance }\end{array}$ & 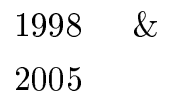 & 2.36 & 2.45 & 42057 & 41236 & $\begin{array}{l}-0.09 \\
(0.12)\end{array}$ \\
\hline$\%$ SC firms with govern- & $1999 \quad \&$ & 3.33 & 3.72 & 42057 & 41236 & -0.39 \\
\hline $\begin{array}{l}\text { ment finance } \\
\% \text { SC firms with electricity }\end{array}$ & $\begin{array}{l}2005 \\
1990,1998 \\
\& 2005\end{array}$ & 5.4 & 5.5 & 62233 & 61085 & $\begin{array}{l}(0.24) \\
-0.10 \\
(0.12)\end{array}$ \\
\hline Family workers depend & ncy & & & & & \\
\hline$\%$ of family employment in & 1990,1998 & 88.92 & 88.93 & 62233 & 61085 & -0.01 \\
\hline $\begin{array}{l}\mathrm{SC} \text { firms } \\
\% \text { of child labour in SC }\end{array}$ & $\begin{array}{l}\& 2006 \\
1999 \&\end{array}$ & 1.55 & 1.57 & 42057 & 41236 & $\begin{array}{l}(0.38) \\
-0.01\end{array}$ \\
\hline firms & 2005 & & & & & $(0.11)$ \\
\hline$\%$ of girls child labour in & $1999 \quad \&$ & 0.42 & 0.38 & 42057 & 41236 & 0.04 \\
\hline $\mathrm{SC}$ firms & 2005 & & & & & $(0.05)$ \\
\hline $\begin{array}{l}\text { Sector mobility } \\
\text { Share of SC firms in low } \\
\text { profile sector }\end{array}$ & 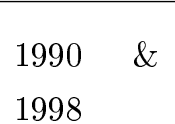 & 0.13 & 0.15 & 67074 & 66892 & $\begin{array}{l}-0.03 \\
(0.02)\end{array}$ \\
\hline Share SC firms in cleaning & 1990,1998 & 0.01 & 0.01 & 91028 & 90347 & 0.002 \\
\hline $\begin{array}{l}\text { and sanitation } \\
\text { Share of SC firms in }\end{array}$ & $\begin{array}{l}\& 2005 \\
1990 \& \&\end{array}$ & 0.02 & 0.03 & 67074 & 66892 & $\begin{array}{l}(0.003) \\
-0.008\end{array}$ \\
\hline transport-animals & 1998 & & & & & $(0.0105)$ \\
\hline Caste and employment & & $\mathrm{Me}$ & & No. o & irms & \\
\hline$\%$ of $\mathrm{SC}$ labour in $\mathrm{SC}$ & $2006-07$ & 0.656 & 0.687 & 3996 & 4224 & -0.0307 \\
\hline $\begin{array}{l}\text { owned firm } \\
\% \text { of Non-SC labour in SC }\end{array}$ & $2006-07$ & 0.343 & 0.312 & 3996 & 4224 & $\begin{array}{l}(0.022) \\
0.030\end{array}$ \\
\hline owned firm & & & & & & $(0.022)$ \\
\hline$\%$ of SC labour in Non-SC & $2006-07$ & 0.075 & 0.071 & 38521 & 38510 & 0.004 \\
\hline $\begin{array}{l}\text { owned firm } \\
\% \text { of Non-SC labour in } \\
\text { Non-SC owned firm }\end{array}$ & $2006-07$ & 0.924 & 0.928 & 38521 & 38510 & $\begin{array}{l}(0.006) \\
-0.004 \\
(0.006)\end{array}$ \\
\hline
\end{tabular}

Note 1) The reported coefficients are mean differences between reserved and control constituencies, from bivariate OLS regression models estimated separately for each variable. Standard errors are clustered by state level in parentheses.

$* \mathrm{p}<0.10, * * \mathrm{p}<0.05, * * * \mathrm{p}<0.01$ 
Table 4.1 shows the mean comparison of the reserved and Control (selected counterfactuals from general constituencies) constituencies for the selected variables used in the analysis. Column 1 and 2 report the mean values of reserved and control constituencies, respectively. Column 3 and 4 show the number of observations (village or firm) in the reserved and control constituencies, respectively. Variables of interest from EC are reported under four board sections: entrepreneurship, accessing public services, the dependency of family labor and sectoral mobility. It is not possible to consider all of the 105,000 villages in the analysis. Because around 89,752 villages have at least one non-agriculture firm, and out of these villages only 41,104 villages have at least one SC owned firm. The variable, the share of SC firms in the village, measuring the business presence of SC is practical for the 89,752 villages which had some presence of non-agricultural activity. The rest of the variables in the Economic Census measure the SC business characteristics in the village. The SC business characteristics variable is possible to construct for the 41,104 villages where SC have participated in business. The number observation for variables also changes, since the EC does not report selected variables in all three census years $(1990,1998$ and 2005). The outcome variables measured using the MSME census were described at the firm level. I use the fourth MSME Census conducted in the year 2006-07 to measure owners' preferences in hiring labor from their castes, as reported under the section of Caste and Employment. 
I estimate an empirical model at all three levels: 1) firm, 2), village and 3) constituency:

$$
Y_{v t}=\alpha+\beta R_{c}+\gamma X_{v}+\zeta_{s}+\varphi_{t}+\eta_{c t}
$$

The equation 1 , where $Y_{v t}$ are outcome variables in village $v$ in year $t$. $c$ represents constituency. The coefficient of interest is $\beta$ : it tells whether the reserved constituencies are different than the counterfactual constituencies. $R_{c}$ is the reservation dummy, $X_{v}$ is the control variable, share of SC population in the village, 1991. $\zeta_{s}$ and $\varphi_{t}$ are state and year fixed effects respectively. The error term, $\eta_{v t}$ is clustered at block level. The results of equation 1 are presented in tables $4.2,4.3,4.4,4.5,4.6,4.12$ and 4.13.

$$
Y_{c t}=\alpha+\beta R_{c}+\gamma X_{c}+\zeta_{s}+\varphi_{t}+\eta_{c t}
$$

The equation 2, $Y_{c t}$ are outcome variables in constituency $c$ in year $t$. $c$ represents constituency. The coefficient of interest is $\beta$ : it tells whether the reserved constituencies are different than the counterfactual constituencies. $R_{c}$ is the reservation dummy, $X_{c}$ is the control variable, share of SC population in the constituency, 1991. $\zeta_{s}$ and $\varphi_{t}$ are state and year fixed effects respectively. The error term, $\eta_{c t}$ is clustered at state level. The results of equation 2 are presented in tables $4.7,4.8,4.9$, and 4.10 .

$$
Y_{i}=\alpha+\beta R_{c}+\gamma X_{v}+\zeta_{s}+\eta_{i}
$$

In equation $3, Y_{i}$ are outcome variables in firm $i$ in village $v . c$ represents constituency. The coefficient of interest is $\beta$ : it tells whether the reserved constituencies are different than the counterfactual constituencies. $R_{c}$ is the reservation dummy, $X_{v}$ is the control variable, share of SC population in the village, 1991. $\zeta_{s}$ is the state fixed effect. The error term, $\eta_{i}$ is clustered at block level. The results of equation 3 are presented in table 4.11. 


\subsection{Results}

\subsubsection{Private sector}

Table 4.2 shows that the effect of political reservation for schedule castes leaders has no effect on overall private sector development or economic growth and, SCs entrepreneurship in the non-agriculture sector. Columns 1 and 4 show that political reservation has no effect on the total number of enterprises and the total number of emploees in reserved villages, respectively. Columns 2 and 3 show that political reservation has no significant effects on the number of SCs enterprises and share of SCs enterprises in the reserved villages. Columns 5 and 6 show that political reservation has no significant effects on the number of SCs enterprises employment and share of SCs enterprises employment in the reserved villages. Column 7 shows that political reservation does not affect the night light intensity (a proxy for economic activity) in the reserved villages. 


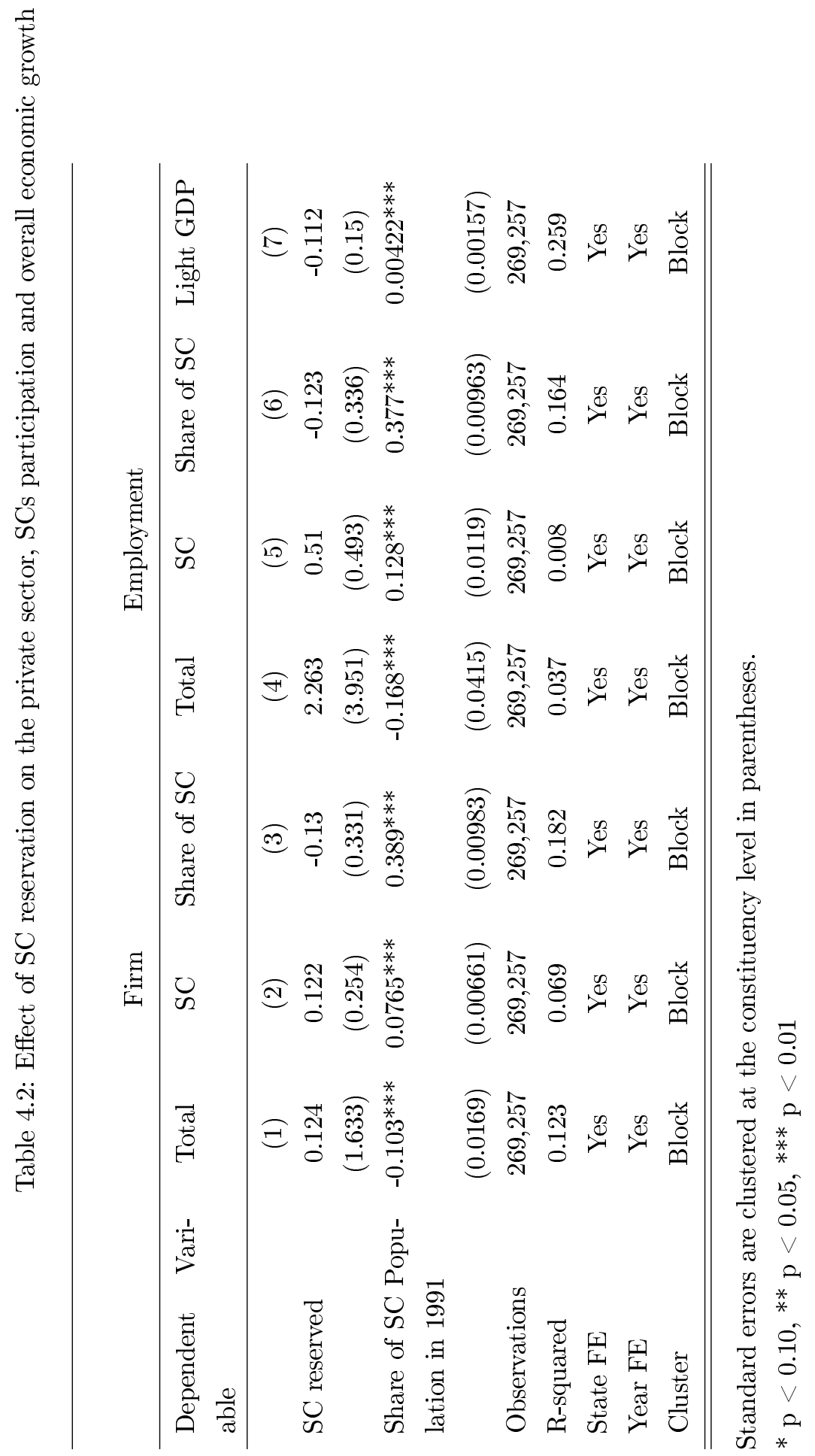




\subsubsection{Entrepreneurship}

Table 4.3 shows that effect of political reservation for schedule castes leaders has no effects on the various entrepreneurship characteristics of non-SCs and SCs. Columns 1 and 2 show that political reservation has no effects on the share of one-person enterprises owned by non-SCs and SCs, respectively. Columns 3 and 4 show that political reservation has no significant effects on the share of no-outside workers' enterprises owned by non-SCs and SCs, respectively. Columns 5 and 6 show that political reservation has no significant effects in the share of at least one outside workers' enterprises owned by non-SCs and SCs, respectively. Columns 5 and 6 show that political reservation has no significant effects on the average employment of enterprises owned by non-SCs and SCs, respectively. 


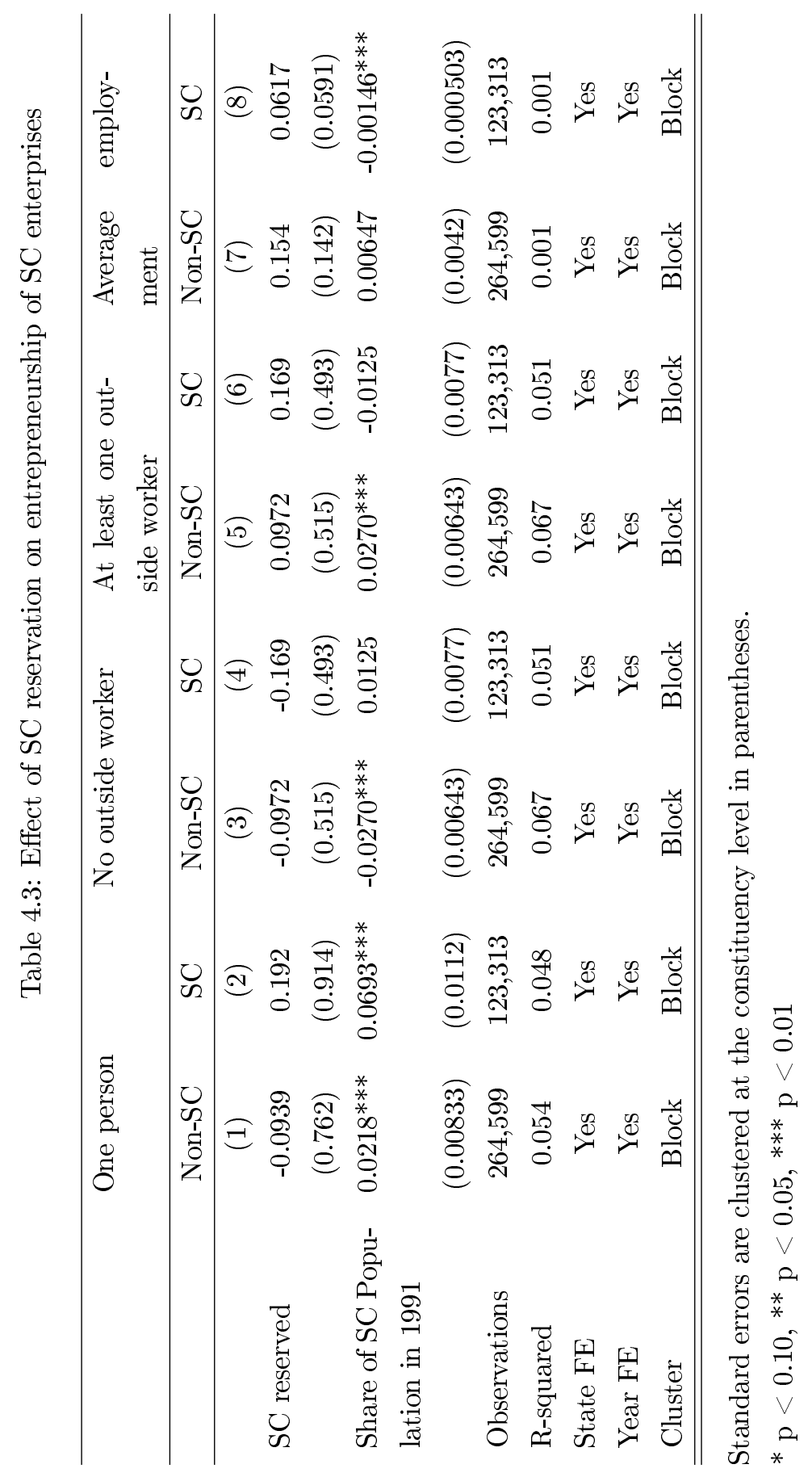




\subsubsection{Access to facilities and government support}

Table 4.4 shows that political reservation for schedule castes leaders has no effects on the non-SCs and SCs firms access to facilities and government support. Columns 1 and 2 show that political reservation has no effects on the firms access to electricity, owned by non-SCs and SCs, respectively. Columns 3 and 4 show that political reservation has no effects on the firms likely to get financial support from the banks, owned by non-SCs and SCs, respectively. Columns 5 and 6 show that political reservation has no effects on firm chance to get financial support from government programmes to the firms, owned by non-SCs and SCs, respectively. Columns 7 and 8 show that political reservation has no effects on the firms ability to be registered, owned by non-SCs and SCs, respectively. 


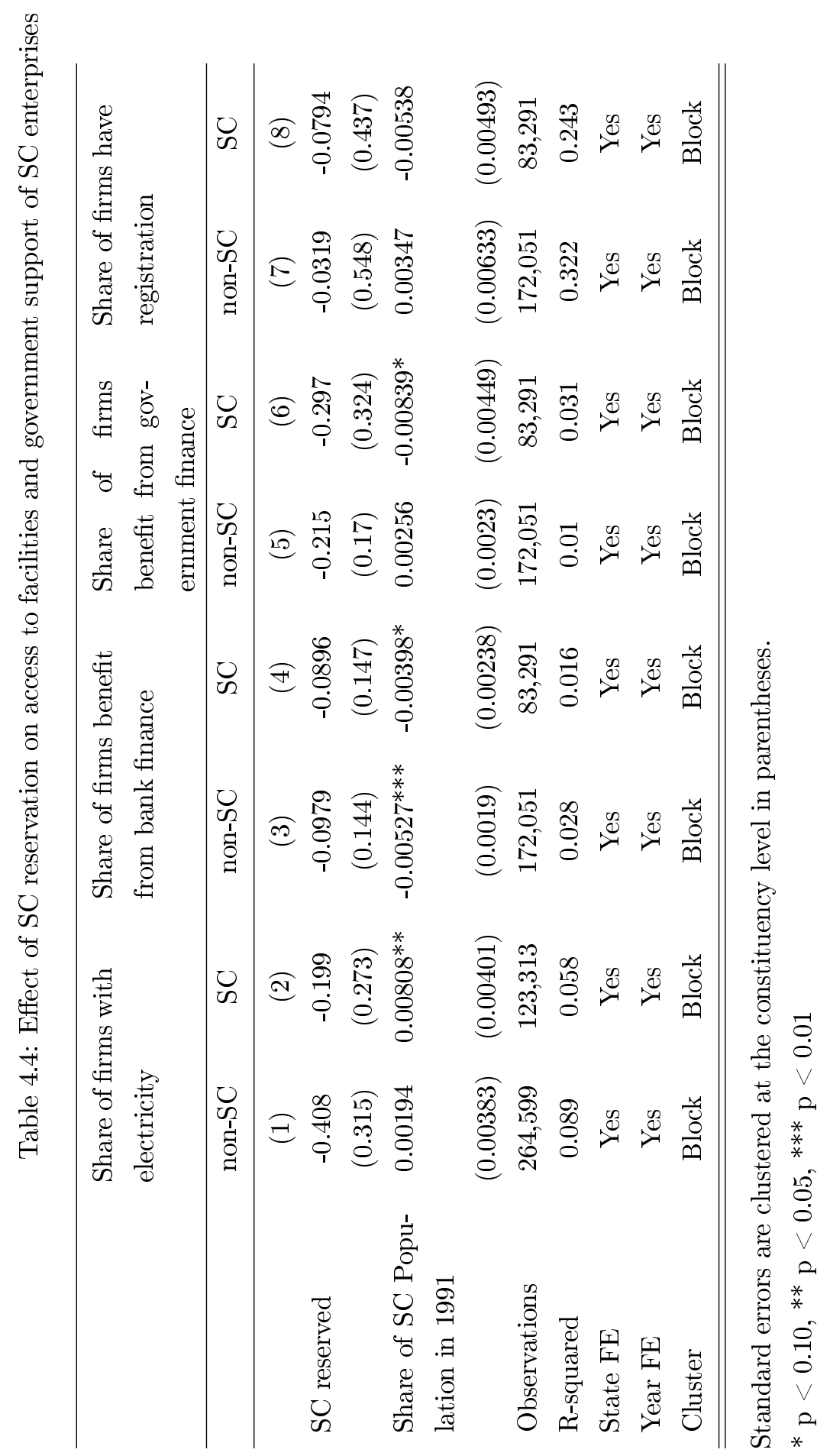




\subsubsection{Family workers}

Table 4.5 shows that political reservation has no effects on non-SCs and SCs firms dependency on family workers and child labor. The expected results with political reservation is that SC entrepreneurs are able to hire laborers freely from the market and are less dependent on family labor. The Scheduled Castes enterprises are highly dependent on the family members (both adult and children) for labor. The caste system prevents hiring workers from other castes. It has two adverse effects: it prevents them from entering into many sectors and results in less educational investments for the successive generation. SC children have unequal access to primary education(Desai et al., 2010) and this is also the reason for SCs firms have higher incidence of child labour as compared to non-SC firm. Columns 1 and 2 show that political reservation has no effects on the average share of family workers in firms, owned by non-SCs and SCs, respectively. Columns 3 and 4 show that political reservation has no effects on the use of child laborers in firms, owned by non-SCs and SCs, respectively. Columns 5 and 6 show that political reservation has no effects on the use of girl child laborers in firms, owned by non-SCs and SCs, respectively.

Table 4.5: Effect of SC reservation on family labor

\begin{tabular}{lcccccc}
\hline & $\begin{array}{l}\text { Share of family } \\
\text { worker in firms }\end{array}$ & \multicolumn{2}{c}{$\begin{array}{l}\text { Share of } \\
\text { worker in firms }\end{array}$} & \multicolumn{2}{c}{$\begin{array}{l}\text { Share of girl child } \\
\text { worker in firms }\end{array}$} \\
\hline & non-SC & SC & non-SC & SC & non-SC & SC \\
\hline \multirow{2}{*}{ SC reserved } & 0.0597 & -0.113 & 0.0388 & -0.00895 & 0.0512 & 0.0338 \\
& $(0.514)$ & $(0.436)$ & $(0.118)$ & $(0.134)$ & $(0.0445)$ & $(0.0481)$ \\
Share of SC & $-0.0222^{* * *}$ & 0.00596 & $-0.00253^{*}$ & $-0.00396^{* * *}$ & $-0.00119^{*}$ & $-0.00186^{* * *}$ \\
Population in & & & & & & \\
1991 & & & & & & \\
& & & & & & \\
Observations & 264,599 & 123,313 & 172,051 & 83,291 & 172,051 & 83,291 \\
R-squared & 0.071 & 0.054 & 0.03 & 0.023 & 0.02 & 0.011 \\
State FE & Yes & Yes & Yes & Yes & Yes & Yes \\
Year FE & Yes & Yes & Yes & Yes & Yes & Yes \\
Cluster & Block & Block & Block & Block & Block & Block \\
\hline \hline
\end{tabular}

Standard errors are clustered at the constituency level in parentheses.

${ }^{*} \mathrm{p}<0.10,{ }^{* *} \mathrm{p}<0.05, * * * \mathrm{p}<0.01$ 


\subsubsection{Business presence in traditional exploitative sectors}

Table 4.6 shows that political reservation has no effects on exploitative sectors. The expected results of political reservation is that $\mathrm{SC}$ entrepreneurs are able to move away from the traditional exploitative sectors. Cleaning and sanitation, animal-powered transport, and human-powered transport are low profile (paid) sectors, where SC are historically exploited via debt bondage and slavery. Columns 2, 4, and 6 show that the coefficient is negative as expected for all sectors, but not statistically significant. The columns 1,3 and 5 show that political reservation has no effect on number of non-SC enterprises in exploitative sectors.

Table 4.6: Effect of SC reservation on traditional exploitative sector(Number of firms

\begin{tabular}{lcccccc}
\hline $\begin{array}{l}\text { Dependent } \\
\text { Variables }\end{array}$ & \multicolumn{2}{l}{ Cleaning and sanitation } & \multicolumn{2}{l}{$\begin{array}{l}\text { Animal-powered } \\
\text { port }\end{array}$} & trans- & \multicolumn{2}{l}{ Man-powered transport } \\
& non-SC & SC & non-SC & SC & non-SC & SC \\
\hline \multirow{2}{*}{ SC reserved } & -0.000925 & -0.000838 & -0.00062 & -0.000382 & -0.0121 & -0.000616 \\
& $(0.00157)$ & $(0.00115)$ & $(0.0272)$ & $(0.0012)$ & $(0.0357)$ & $(0.0108)$ \\
Share of SC & $-1.70 \mathrm{e}-05^{*}$ & $1.13 \mathrm{E}-05$ & $-0.000379^{* *}$ & $6.94 \mathrm{e}-05^{* * *}$ & 0.000664 & $0.000754^{* * *}$ \\
Population in & & & & & & \\
1991 & & & & & & \\
& & & & & & \\
Observations & 269,257 & 269,257 & 178,329 & 178,329 & 178,329 & 178,329 \\
R-squared & 0.003 & 0.003 & 0.028 & 0.007 & 0.04 & 0.03 \\
State FE & Yes & Yes & Yes & Yes & Yes & Yes \\
Year FE & Yes & Yes & Yes & Yes & Yes & Yes \\
Cluster & Block & Block & Block & Block & Block & Block \\
\hline \hline
\end{tabular}

Standard errors are clustered at the constituency level in parentheses.

${ }^{*} \mathrm{p}<0.10,{ }^{* *} \mathrm{p}<0.05,{ }^{* * *} \mathrm{p}<0.01$ 


\subsubsection{Business sector and patronage}

Table 4.7 shows that political reservation has a significant effect in the rent-seeking sectors (gas and water) and no effect on other sectors. Number of SC firms in gas and water sector are higher in reserved SC constituencies as compared to the general/counterfactual constituencies. The column 4 shows that political reservation increases the SCs ownership in gas sector. In India, gas distribution is a monopolised business. In 2005, there are around one gas distribution agent at every constituency. Because of monopoly, this sector has a place for political patronage. The column 6 shows that political reservation increases the SCs ownership in the water sector. Private water tanker business is a highly profitable business, the price of tanker water is many times higher than pipe-water provided government. In severe water shortages period, the private tankers supply water from rural areas to affluent customers in urban areas (Srinivasan et al., 2010). In developing countries, private water tanker business is classified under small-scale service providers. This sector subject to excessive political interference and corruption. Water extraction often lead over-exploitation of groundwater resources (Lovei and Whittington, 1991; Tan, 2015). In India, water tanker business required a license and there are strict rules to follow where to extract water and what is the limit. Some water tankers operate without a license, and they do not follow the rules (Janakarajan et al., 2006; Shah, 2007). 


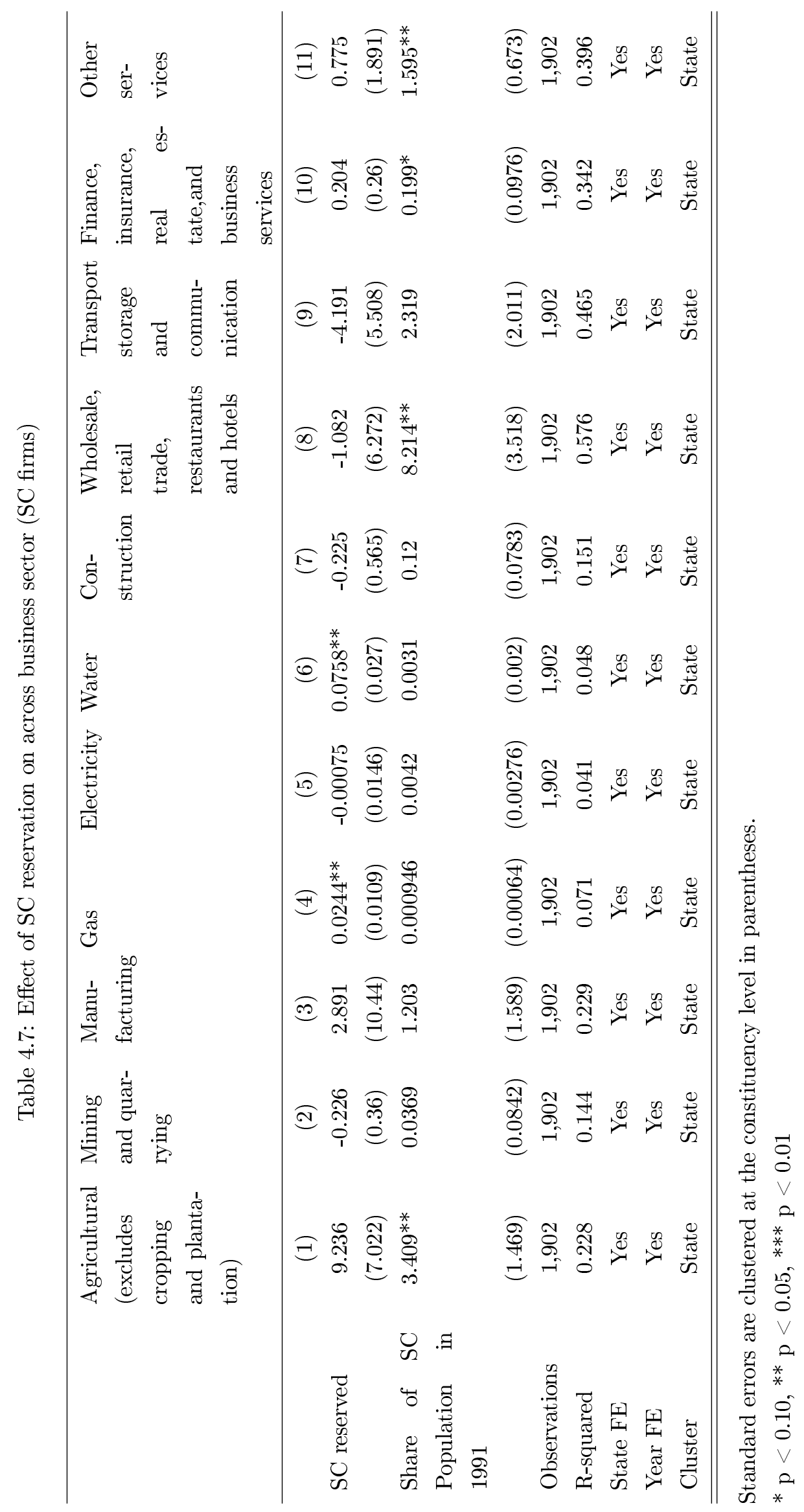


Table 4.8 shows that political reservation has a significant effect in the rent-seeking sectors (gas and water) and no effect on other sectors. Number of employees in SC owned firms in gas and water sectors are higher in reserved constituencies as compared to the general counterfactual constituencies. The results in table 4.7 are echoed here. 


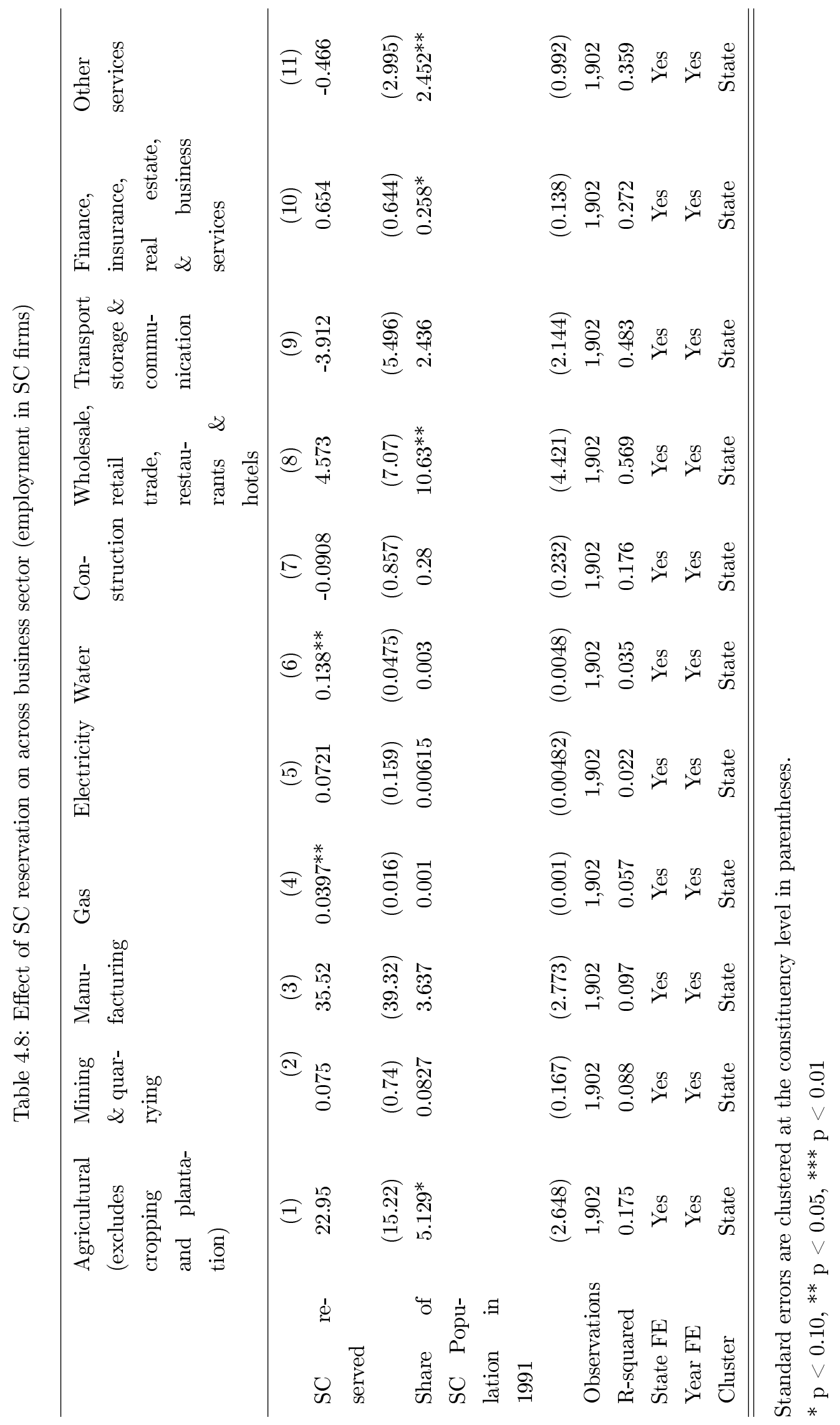


Table 4.9 shows that political reservation has no effect in the business of Non-SC entrepreneurs across sectors. The number of non-SC firms have not declined or increased in the reserved constituencies. Higher private tanker business is a sign of failure in public water services and lack of water management. Column 6 , shows there is no overall increase in water tanker business. Thus, prove that public goods delivery is not affected by reservation. 


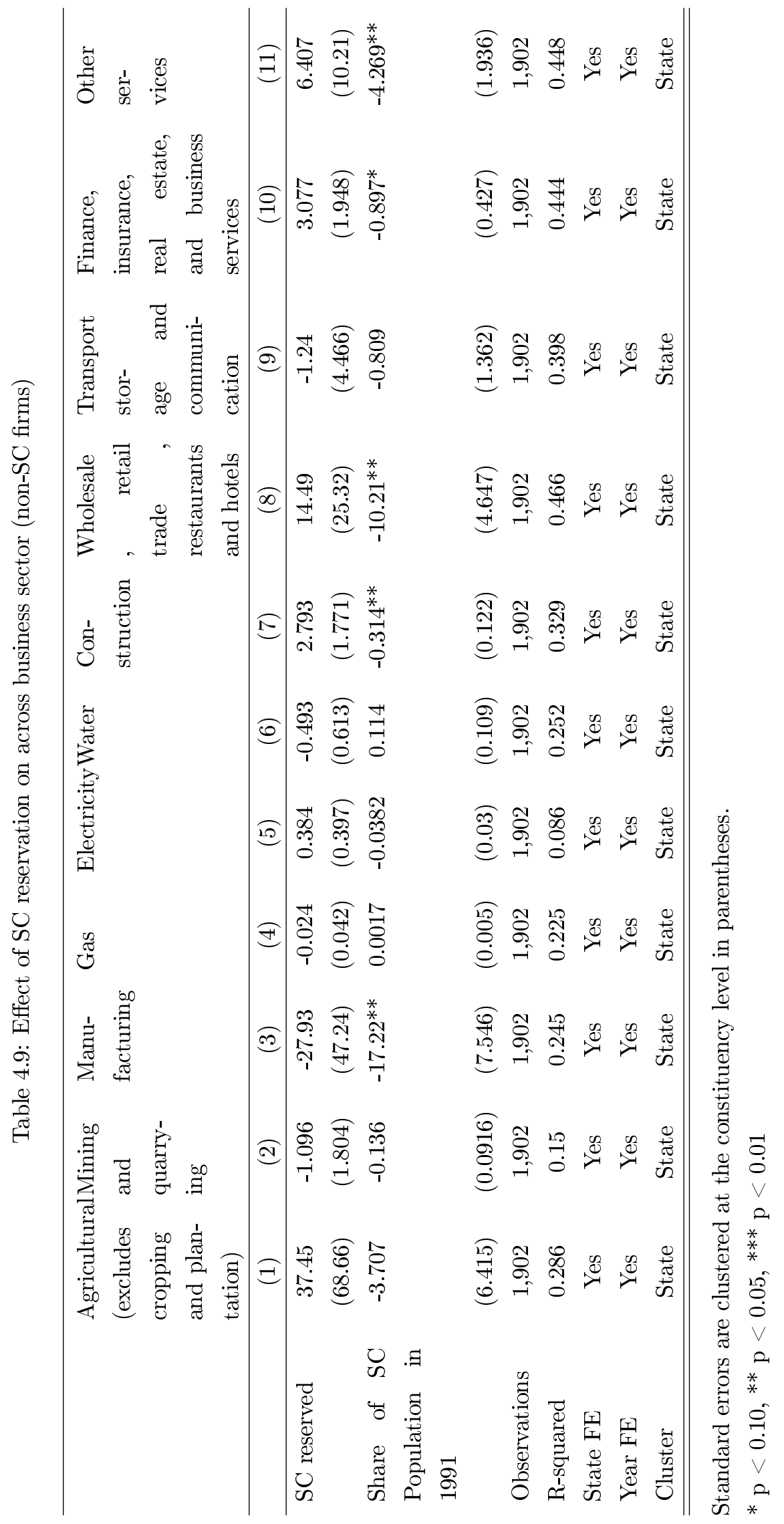


Table 4.10 shows that political reservation has no effect in the business of Non-SC entrepreneurs across sectors, except in the sector, wholesale, retail trade, restaurants, and hotels. The employment of non-SC firms in wholesale, retail trade, restaurants and hotels sector is higher in reserved constituencies than the general constituencies, the statistically significant at 10 percent. Since it is a large informal sector, the rise of the informal sector could be interpreted as a negligible negative impact due to the reservation. 


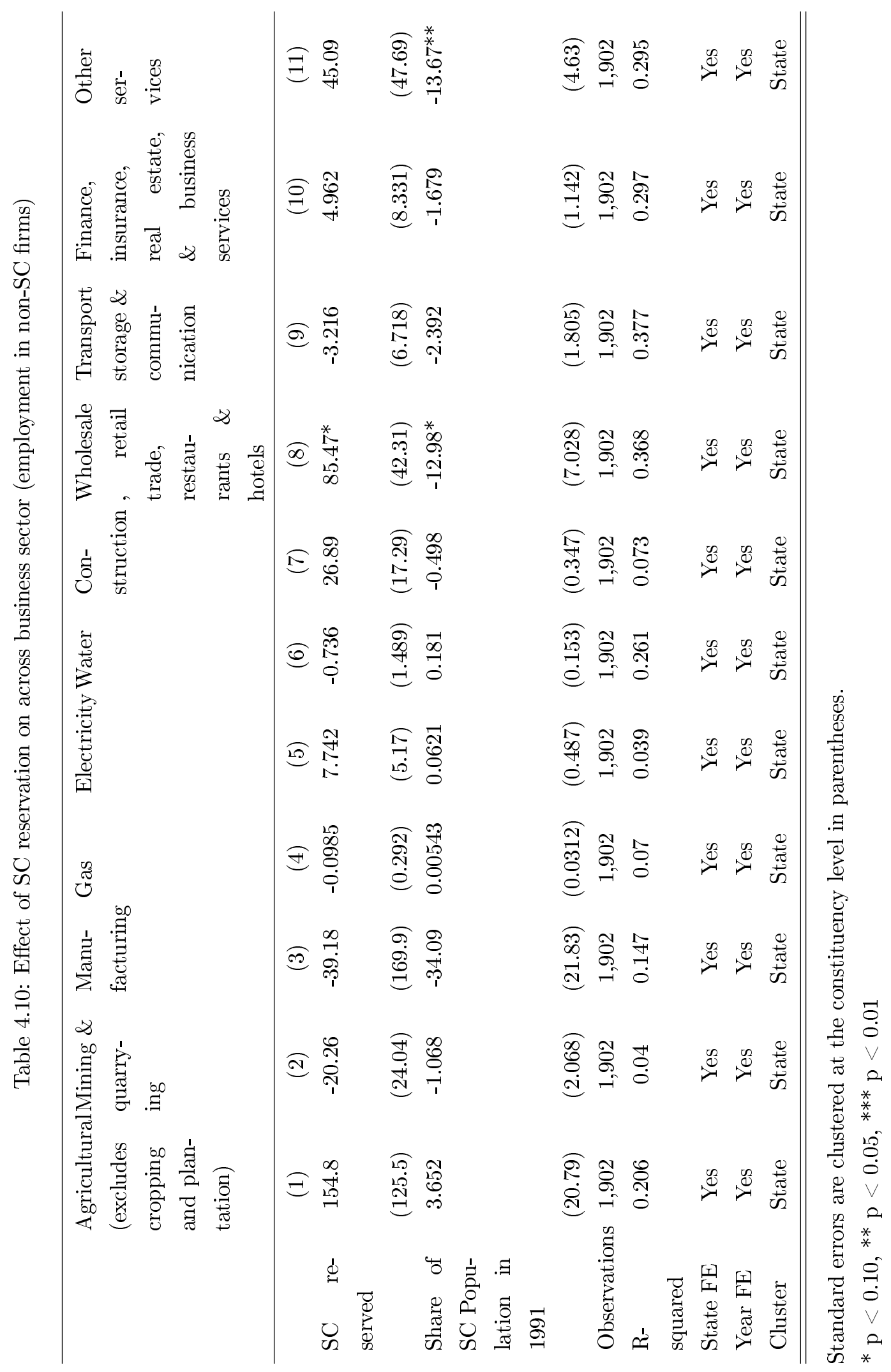




\subsubsection{Caste and employment}

Table 4.11 shows that political reservation has no effects on owners' preference in hiring members of their caste. Table 4.1 results have based the firms with more than one employee. The expected results of political reservation is that SC owners are able to hire labor from other castes and non-SC entrepreneurs hire SC labor. Column 1 and 2 show that coefficients are not significant and are an unexpected sign. The effect of reservation on SC firms did not lead to hiring more non-SC laborers, and the coefficient is negative (See column 2). Column 3 and four also show that coefficients are not significant and are an unexpected sign. The effect of reservation on non-SC firms did not lead to hiring more SC labour.

Table 4.11: Effect of SC reservation on firms' hiring patterns

\begin{tabular}{l|cc|cc}
\hline & \multicolumn{2}{|c|}{ SC firms } & \multicolumn{2}{c}{ Non-SC firms } \\
& SC employment & Non-SC employment & SC employment & Non-SC employment \\
\hline \multirow{2}{*}{ SC Reservation } & $(1)$ & $(2)$ & $(3)$ & $(4)$ \\
& -0.0152 & 0.0152 & 0.00478 & -0.00478 \\
SC Population in 2001 & $(0.0207)$ & $(0.0207)$ & $(0.00435)$ & $(0.00435)$ \\
& $0.00125^{* * *}$ & $-0.00125^{* * *}$ & $0.00102^{* * *}$ & $-0.00102^{* * *}$ \\
Observations & $(0.000444)$ & $(0.000444)$ & $(0.000135)$ & $(0.000135)$ \\
R-squared & 8,220 & 8,220 & 77,031 & 77,031 \\
State FE & 0.194 & 0.194 & 0.065 & 0.065 \\
Cluster & Yes & Yes & Yes & Yes \\
\hline \hline
\end{tabular}

Standard errors are clustered at the constituency level in parentheses.

${ }^{*} \mathrm{p}<0.10,{ }^{* *} \mathrm{p}<0.05,{ }^{* * *} \mathrm{p}<0.01$ 


\subsubsection{Intra-village effect}

The table 4.12 attempt to confirm that is there an intra-village effect of SCs reservation. The empirical expectation is that leaders could favor only to villages which have share of SCs population. The results presented in the table 12 confirms that there is no evidence of intra-village effect.

Table 4.12: Intra-village effect of SC reservation on the private sector, SCs participation and overall economic growth

\begin{tabular}{|c|c|c|c|c|c|c|c|}
\hline & \multicolumn{3}{|c|}{ Firm } & \multicolumn{3}{|c|}{ Employment } & \multirow[b]{2}{*}{$\begin{array}{l}\text { Light } \\
\text { GDP }\end{array}$} \\
\hline & Total & $\mathrm{SC}$ & $\begin{array}{l}\text { Share of } \\
\mathrm{SC}\end{array}$ & Total & $\mathrm{SC}$ & $\begin{array}{l}\text { Share of } \\
\mathrm{SC}\end{array}$ & \\
\hline & (1) & $(2)$ & (3) & (4) & $(5)$ & (6) & $(7)$ \\
\hline SC reserved & -0.115 & 0.0812 & -0.324 & 0.904 & 0.173 & -0.32 & -0.0876 \\
\hline & $(2.207)$ & $(0.299)$ & $(0.413)$ & $(5.069)$ & $(0.544)$ & $(0.411)$ & $(0.177)$ \\
\hline \multirow{2}{*}{$\begin{array}{l}\text { Share of SC Pop- } \\
\text { ulation in } 1991\end{array}$} & $-0.108^{* * *}$ & $0.0756^{* * *}$ & $0.385^{* * *}$ & $-0.196 * * *$ & $0.121^{* * *}$ & $0.373^{* * *}$ & $0.00524^{* *}$ \\
\hline & -0.0289 & -0.0104 & -0.0143 & -0.0602 & -0.0158 & -0.0142 & -0.00257 \\
\hline $\mathrm{SC}$ reserved*SC & 0.00986 & 0.0017 & 0.00801 & 0.0561 & 0.0139 & 0.00814 & -0.00107 \\
\hline \multirow{3}{*}{$\begin{array}{l}\text { Population in } \\
1991\end{array}$} & & & & & & & \\
\hline & & & & & & & \\
\hline & $(0.0419)$ & $(0.0155)$ & $(0.0209)$ & $(0.0967)$ & $(0.0272)$ & $(0.0205)$ & $(0.00381)$ \\
\hline Observations & 269,257 & 269,257 & 269,257 & 269,257 & 269,257 & 269,257 & 256,660 \\
\hline R-squared & 0.123 & 0.069 & 0.182 & 0.037 & 0.008 & 0.164 & 0.259 \\
\hline State FE & Yes & Yes & Yes & Yes & Yes & Yes & Yes \\
\hline Year FE & Yes & Yes & Yes & Yes & Yes & Yes & Yes \\
\hline Cluster & Block & Block & Block & Block & Block & Block & Block \\
\hline
\end{tabular}

Standard errors are clustered at the constituency level in parentheses.

${ }^{*} \mathrm{p}<0.10,{ }^{* *} \mathrm{p}<0.05,{ }^{* * *} \mathrm{p}<0.01$ 


\subsubsection{Public sector}

Though the primary object of the paper is to examine the effect of political reservation in the private sector. Presence of public sector in the reserved constituencies is advantageous to the SCs. Because Indian constitution guarantees job for SCs in the public-sector firms. The empirical expectation is that $\mathrm{SC}$ leaders favor their caste by bringing more public-sector firms to their constituencies. Table 4.13 shows that reservation has no effects on the public sector.

Table 4.13: Effect of SC reservation on the public sector

\begin{tabular}{lcccc}
\hline & \multicolumn{2}{c}{ Firm } & \multicolumn{2}{c}{ Employment } \\
\hline SC reserved & $(1)$ & $(2)$ & $(3)$ & $(4)$ \\
& 0.0135 & -0.0226 & -0.337 & -0.217 \\
Share of SC Population in 1991 & $(0.0817)$ & $(0.0934)$ & $(0.547)$ & $(0.841)$ \\
& $-0.00316^{* * *}$ & $-0.00393^{* *}$ & -0.0144 & -0.0118 \\
SC reserved*SC Population in 1991 & $(0.00105)$ & $(0.00155)$ & $(0.0142)$ & $(0.0269)$ \\
& & 0.00149 & & -0.00493 \\
Observations & & -0.00206 & & -0.0276 \\
R-squared & 269,257 & 269,257 & 269,257 & 269,257 \\
State FE & 0.134 & 0.134 & 0.011 & 0.011 \\
Year FE & Yes & Yes & Yes & Yes \\
Cluster & Yes & Yes & Yes & Yes \\
\hline \hline
\end{tabular}

Standard errors are clustered at the constituency level in parentheses.

${ }^{*} \mathrm{p}<0.10,{ }^{* *} \mathrm{p}<0.05,{ }^{* * *} \mathrm{p}<0.01$ 


\subsection{Conclusions}

The main finding of this paper shows that SC political leaders' preference in the constituency cause patronage in the rent-seeking sectors but do not promote their castes in the private non-agricultural sectors. The empirical expectation of this paper is that SC leaders act in favour of SC in areas where SC are excluded. In the private non-agriculture sector, SC have low ownership and low employment, and there is noticeable underperformance of SC firms in various scale measures. In the future Indian economy, the private non-agriculture sectors are the livelihood for majorities of Indian families. Exclusion of SC in the private non-agricultural sectors is a sign of social imbalance in the transforming Indian economy. This paper is not arguing that SC leaders' lack of preference in the constituency works represents a failure in establishing political quotas. It could be that leaders do not influence business outcomes as the result of the following factors: SC leaders' priorities are not on the business outcomes; vote seeking behaviour; and that they have limited instruments at their disposal to influence overall business outcomes. 


\section{Bibliography}

AfRIDI, F. (2011): "The impact of school meals on school participation: Evidence from rural India," Journal of Development Studies, 47, 1636-1656.

Afridi, F., V. Iversen, AND M. Sharan (2013): "Women political leaders, corruption and learning: Evidence from a large public program in India," Working Paper.

Afridi, F., A. Mukhopadhyay, And S. SAhoo (2012): "Female labour force participation and child education in India: The effect of the national rural employment guarantee scheme," Working Paper.

Ahluwalia, M. S. (2002): "Economic reforms in India since 1991: Has gradualism worked?" The Journal of Economic Perspectives, 16, 67-88.

Aidt, T. S., M. A. Golden, And D. TiWARI (2011): "Incumbents and criminals in the Indian national legislature," Working Paper.

Arrow, K. J. (1951): Social choice and individual values, Yale University Press.

Asher, S. AND P. Novosad (2017): "Politics and local economic growth: Evidence from India," American Economic Journal: Applied Economics, 9, 229-273.

Ashrafi, H. (2009): "Gender dimension of agriculture and rural employment: Special focus on Afghan rural women's access to agriculture and rural development sector," International Fund for Agricultural Development, Rome, Italy.

AzAm, M. (2011): "The impact of Indian job guarantee scheme on labor market outcomes: Evidence from a natural experiment," Working Paper.

BAN, R. AND V. RAO (2008): "Tokenism or agency? The impact of women's reservations on village democracies in south India," Economic Development and Cultural Change, 56, $501-530$.

Banerjee, A., D. P. Green, J. Mcmanus, And R. Pande (2014): "Are poor voters indifferent to whether elected leaders are criminal or corrupt? A vignette experiment in rural India," Political Communication, 31, 391-407.

Bardhan, P., D. Mookherjee, and M. L. Parra Torrado (2005): "Impact of political reservations in West Bengal local governments on public service provision," Tech. rep., Boston University Working Paper.

Bardhan, P. K., D. MoOkherjee, And M. PArra Torrado (2010a): "Impact of political reservations in West Bengal local governments on anti-poverty targeting," Journal of Globalization and development, 1. 
Bardhan, P. K., D. Mookherjee, And M. P. Torrado (2010b): "Impact of political reservations in West Bengal local governments on anti-poverty targeting," Journal of Globalization and development, 1.

Beaman, L., E. Duflo, R. Pande, And P. Topalova (2012): "Female leadership raises aspirations and educational attainment for girls: A policy experiment in India," science, $335,582-586$.

Beaman, L., E. Duflo, R. Pande, P. Topalova, et Al. (2010): "Political reservation and substantive representation: Evidence from Indian village councils," in India Policy Forum 2010/11 Volume, vol. 7, 159-191.

Besley, T. And S. CoATE (1997): "An economic model of representative democracy," The Quarterly Journal of Economics, 112, 85-114.

Besley, T., R. Pande, L. Rahman, and V. Rao (2004): "The politics of public good provision: Evidence from Indian local governments," Journal of the European Economic Association, 2, 416-426.

Besley, T., R. Pande, And V. RaO (2005): "Participatory democracy in action: Survey evidence from South India," Journal of the European Economic Association, 3, 648-657.

Betancourt, R. And S. Gleason (2000): "The allocation of publicly-provided goods to rural households in India: on some consequences of caste, religion and democracy," World Development, 28, 2169-2182.

Bhalotra, S. And I. Clots-Figueras (2014): "Health and the political agency of women," American Economic Journal: Economic Policy, 6, 164-97.

Bhavnani, R. R. (2014): "India National and State Election Dataset. Harvard Dataverse Network," .

Binswanger-Mkhize, H. P., H. K. Nagarajan, And S. K. Singh (2012): "Impacts of public spending, private spending and school governance on schooling outcomes in rural India," Working Paper.

Blair, H. (2017): "Constituency development funds in India," Economic and Political Weekly, 52, 99.

BlumberG, R. L. (1988): "Income under female versus male control: Hypotheses from a theory of gender stratification and data from the Third World," Journal of Family Issues, $9,51-84$.

BoB, C. (2007): "Dalit rights are human rights: Caste discrimination, international activism, and the construction of a new human rights issue," Human Rights Quarterly, 167-193.

Bonu, S., M. Rani, D. H. Peters, And T. D. BAKer (2011): "Empowering the "socially excluded'in rural local governments: An exploratory study from a state in India," Journal of International Development, 23, 42-62.

Bose, N. (2017): "Raising consumption through India's National Rural Employment Guarantee Scheme," World Development, 96, 245-263. 
Burchi, F. And P. De Muro (2016): "Measuring human development in a high-income country: A conceptual framework for well-being indicators," in Forum for Social Economics, Taylor \& Francis, vol. 45, 120-138.

Chari, A. V., P. Glick, E. Okeke, And S. V. Srinivasan (2019): "Workfare and infant health: Evidence from India's public works program," Journal of Development Economics, $138,116-134$.

Chattopadhyay, R. And E. Duflo (2004a): "Impact of reservation in Panchayati Raj: Evidence from a nationwide randomised experiment," Economic and Political Weekly, 979986.

(2004b): "Women as policy makers: Evidence from a randomized policy experiment in India," Econometrica, 72, 1409-1443.

Chin, A. AND N. PRAKASH (2011): "The redistributive effects of political reservation for minorities: Evidence from India," Journal of Development Economics, 96, 265-277.

Chopra, V. K. (1996): Marginal players in marginal assemblies: The Indian MLA, Orient Longman.

Clots-Figueras, I. (2011): "Women in politics: Evidence from the Indian States," Journal of public Economics, 95, 664-690.

(2012): "Are female leaders good for education? Evidence from India," American Economic Journal: Applied Economics, 4, 212-44.

Cox, G. W. And M. D. MCCubBins (2005): Setting the agenda: Responsible party government in the US House of Representatives, Cambridge University Press.

Crespo-Cuaresma, J., P. Sauer, And S. KC (2013): "Gini coefficients of educationals attainment: Age group specific trends in educational (in) equality," Tech. rep., Princeton.

DAmOdARAN, H. (2008): India's new capitalists: caste, business, and industry in a modern nation, Springer.

Deininger, K., S. Jin, H. K. Nagarajan, and F. Xia (2015): "Does female reservation affect long-term political outcomes? Evidence from rural India," The Journal of Development Studies, 51, 32-49.

DeJARDin, A. K. (1996): Public works programmes, a strategy for poverty alleviation: The gender dimension, International Labour Office, Development and Technical Cooperation Department.

Del Ninno, C., K. Subbarao, And A. Milazzo (2009): How to make public works work: A review of the experiences, World Bank, Human Development Network.

Desai, S., C. D. AdAms, And A. Dubey (2010): "Segmented schooling: inequalities in primary education," Blocked by Caste: Discrimination and Social Exclusion in Modern India, 230-52.

Desai, S. And A. Dubey (2012): "Caste in 21st century India: Competing narratives," Economic and political weekly, 46, 40. 
DeshPande, A. And S. Sharma (2016): "Disadvantage and discrimination in selfemployment: caste gaps in earnings in Indian small businesses," Small Business Economics, $46,325-346$.

Dolan, C. And K. Sutherland (2002): "Gender and employment in the Kenya horticulture value chain," Globalisation and Poverty Discussion Paper, 8.

Dongre, A. A. (2010): "Female political leadership and the prevalence of water borne diseases: Evidence from a natural experiment in India," .

Doss, C., M. Truong, G. Nabanoga, And J. NamaAlwa (2012): "Women, marriage and asset inheritance in Uganda," Development Policy Review, 30, 597-616.

Downs, A. (1957): "An economic theory of political action in a democracy," Journal of political economy, 65, 135-150.

DrÈze, J. AND A. GOYAL (2003): "Future of mid-day meals," Economic and political weekly, 4673-4683.

Dunning, T. And J. NilekAni (2013): "Ethnic quotas and political mobilization: caste, parties, and distribution in Indian village councils," American Political Science Review, $107,35-56$.

DutTA, B. AND P. Gupta (2012): "How do Indian voters respond to candidates with criminal charges: Evidence from the 2009 Lok Sabha elections," .

Edmonds, E. V., N. Pavcnik, And P. Topalova (2010): "Trade adjustment and human capital investments: Evidence from Indian tariff reform," American Economic Journal: Applied Economics, 2, 42-75.

FEnno, R. F. And R. F. FEnNo JR (1978): Home style: House members in their districts, HarperCollins,.

GadDis, I. And S. Klasen (2011): "A re-assessment of the feminization U hypothesis," Working Paper.

GirarD, V. (2018): "Don't touch my road. Evidence from India on affirmative action and everyday discrimination," World Development, 103, 1-13.

GLICK, P. (2002): "Women's employment and its relation to children's health and schooling in developing countries: Conceptual links, empirical evidence, and policies," Working Paper.

Glick, P. And D. E. SAHn (1998): "Maternal labour supply and child nutrition in West Africa," Oxford Bulletin of Economics and Statistics, 60, 325-355.

Gopalan, C., B. V. Rama Sastri, and S. C. Balasubramanian (1991): "Nutritive value of Indian food. revised and updated by Narasinga Rao BS," Deosthale YG, Pant KC, National Institute of Nutrition, Indian Council of Medical Research, Hyderabad, India.

Gopalan, C., B. V. Ramasastri, And S. C. Balasubramanian (2000): "Nutritive Value of Indian Foods (update by BS Narasinga Rao, YG Deosthale and KC Pant) Hyderabad: National Institute of Nutrition," . 
Grown, C., G. R. Gupta, And A. Kes (2005): "UN Millennium project task force on education and gender equality," Taking Action: Achieving gender equality and empowering women, 39.

HAmbly, H. AND S. SARApura (2009): "Ensuring gender equality in capacity development-opportunities for rural employment and sustainable development," Working Paper.

Henderson, J. V., A. Storeygard, And D. N. Weil (2012): "Measuring economic growth from outer space," American economic review, 102, 994-1028.

Heong, K. L. And M. M. Escalada (1997): Pest management of rice farmers in Asia, The International Rice Research Institute.

Hoffman, L. W. (1989): "Effects of maternal employment in the two-parent family." American Psychologist, 44, 283.

Horowitz, D. L. (2001): Ethnic groups in conflict, updated edition with a new preface, University of California Press.

IMBERT, C. AND J. PAPP (2015): "Labor market effects of social programs: Evidence from India's employment guarantee," American Economic Journal: Applied Economics, 7, 23363.

Islam, M. AND A. SivasankARAN (2014): "How does child labor respond to changes in adult work opportunities? Evidence from NREGA," Working Paper.

Iyer, L., T. Khanna, And A. VARshney (2013): "Caste and entrepreneurship in India," Economic and Political Weekly, 48, 52-60.

Janakarajan, S., M. Llorente, And M. H. ZÉRAH (2006): "Urban water conflicts in Indian cities: Man-made scarcity as a critical factor," Urban water conflicts: an analysis of the origins and nature of water-related unrest and conflicts in the urban context. Paris: UNESCO, 91-111.

JAYAL, N. G. (2006): "Engendering local democracy: The impact of quotas for women in India's panchayats," Democratisation, 13, 15-35.

JefFrey, C. (2002): "Caste, class, and clientelism: A political economy of everyday corruption in rural North India," Economic Geography, 78, 21-41.

Jensenius, F. R. (2015): "Development from representation? A study of quotas for the scheduled castes in India," American Economic Journal: Applied Economics, 7, 196-220.

Jensenius, F. R. And P. Suryanarayan (2015): "Fragmentation and decline in india's state assemblies," Asian Survey, 55, 862-881.

JoDHKA, S. S. (2010): "Dalits in business: Self-employed scheduled castes in North-West India," Economic and Political Weekly, 41-48.

KABEER, N. (2008): Mainstreaming gender in social protection for the informal economy, Commonwealth Secretariat.

Kalaramadam, S. (2018): "Presence into participation and representation: Gender quotas in local governance in India," Journal of South Asian Development, 13, 1-23. 
KARAK, M. AND S. RAY (2015): "Women in NREGA: Issues of child care," Tech. rep.

Khera, R. AND N. NAYAK (2009): "Women Workers and perceptions of the National rural employment Guarantee act," Economic and Political Weekly, 49-57.

Kingdon, J. W. (1989): Congressmen's voting decisions, University of Michigan Press.

Klasen, S. And J. Pieters (2012): "Push or pull? Drivers of female labor force participation during India's economic boom," Working Paper.

Klonner, S. And C. Oldiges (2014): "Safety net for India's poor or waste of public funds? Poverty and welfare in the wake of the world's largest job guarantee program," .

Kurer, O. (1993): "Clientelism, corruption, and the allocation of resources," Public Choice, $77,259-273$.

LEE, D. S. (2008): "Randomized experiments from non-random selection in US House elections," Journal of Econometrics, 142, 675-697.

Lehne, J., J. N. Shapiro, And O. V. Eynde (2018): "Building connections: Political corruption and road construction in India," Journal of Development Economics, 131, 6278 .

LERCHE, J. (2008): "Transnational advocacy networks and affirmative action for Dalits in India," Development and Change, 39, 239-261.

Lovei, L. And D. WhitTington (1991): Rent seeking in water supply, World Bank.

LuCi, A., J. JÜtTing, And C. Morrisson (2012): "Why do so many women end up in 'Bad Jobs'? A cross-country assessment for developing countries," The European Journal of Development Research, 24, 530-549.

MAity, B. (2015): "Rural employment guarantee, women's participation and children's welfare: Evidence from India," Working Paper.

Mashiri, M., S. Thevadasan, And R. Zukulu (2005): "Community-based labourintensive road construction: Findings of an impact study Amadiba Road," Working Paper.

Mayhew, D. R. (1974): Congress: The electoral connection, Yale University Press.

MSME (2006-07): "Fourth All India Census of Micro, Small and Medium Enterprises 200607," Development Commissioner of MSME.

Munshi, K. And M. Rosenzweig (2009): "Why is mobility in India so low? Social insurance, inequality, and growth," Working Paper.

Muralidharan, K., P. Niehaus, And S. Sukhtankar (2017): "General equilibrium effects of (improving) public employment programs: Experimental evidence from india," Working Paper.

Narasingha RaO, B., Y. Deosthale, And K. Pant (1989): "Nutrient composition of Indian foods. National Institute of Nutrition," Indian council of medical research, 156.

NigAm, A. (2002): "In search of a Bourgeoisie: Dalit politics enters a new phase," Economic and Political Weekly, 1190-1193. 
Olcott, M. (1944): "The caste system of India," American Sociological Review, 648-657.

Oommen, M. A. (2010): "Have the State Finance Commissions fulfilled their constitutional mandates?" Economic and Political Weekly, 39-44.

Osborne, M. J. And A. Slivinski (1996): "A model of political competition with citizencandidates," The Quarterly Journal of Economics, 111, 65-96.

PANAGARIYA, A. And M. Mukim (2014): "A comprehensive analysis of poverty in India," Asian Development Review, 31, 1-52.

PANDA, S. M. (2006): Women's collective action and sustainable water management: Case of SEWA's water campaign in Gujarat, India, IFPRI.

PANDAY, P. K. (2008): "Representation without participation: Quotas for women in Bangladesh," International Political Science Review, 29, 489-512.

PANDE, R. (2003): "Can mandated political representation increase policy influence for disadvantaged minorities? Theory and evidence from India," American Economic Review, 93, 1132-1151.

PANKAJ, A. AND R. TANKha (2010): "Empowerment effects of the NREGS on women workers: a study in four states," Economic and Political Weekly, 45-55.

Phipps, S. A. And P. S. Burton (1998): "What's mine is yours? The influence of male and female incomes on patterns of household expenditure," Economica, 65, 599-613.

PlanNing Commission (2003): "Identification of districts for wage and self employment programmes," Report of the task force.

_ (2011): "Mid-term appraisal: eleventh five year plan 2007-2012," Tech. rep.

POPKIn, B. M. AND F. S. Solon (1976): "Income, time, the working mother and child nutriture." Journal of Tropical Pediatrics and Environmental Child Health, 22, 156-166.

POWLEY, E. (2007): "Rwanda: The impact of women legislators on policy outcomes affecting children and families: The state of the world's children," Working Paper.

Quisumbing, A. R. And L. Pandolfelli (2010): "Promising approaches to address the needs of poor female farmers: Resources, constraints, and interventions," World Development, 38, 581-592.

Quisumbing, M. A. R. And Y. Yohannes (2005): How fair is workfare?: Gender, public works, and employment in rural Ethiopia, vol. 3492, World Bank Publications.

RaAbe, K., M. Sekher, R. Birner, Et AL. (2009): "The effects of political reservations for women on local governance and rural service provision," Tech. rep., International Food Policy Research Institute (IFPRI).

Rajaraman, I. And M. Gupta (2012): "Public expenditure choices and gender quotas," Indian growth and development review, 5, 108-130.

RAvi, S. AND M. ENGler (2015): "Workfare as an effective way to fight poverty: The case of India's NREGS," World Development, 67, 57-71. 
Robinson, J. A. And R. Torvik (2005): "White elephants," Journal of Public Economics, 89, 197-210.

SAHAi, C. S. (2014): "Mid-Day Meal Scheme: Achievements and challenges," International Journal of Humanities and Social Science Invention, 3, 6-9.

Schneider, M. (2014): "Does clientelism work? A test of guessability in India," in Annual Meeting of the Midwest Political Science Association.

SEN, A. (1999): "Freedom as development," .

Shah, M. And B. M. Steinberg (2015): "Workfare and human capital investment: Evidence from India," Working Paper.

SHAH, T. (2007): "Issues in reforming informal water economies of low-income countries: examples from India and elsewhere," Community-based water law and water resource management reform in developing countries, 65-95.

Singh, A., A. PARK, And S. Dercon (2013): "School meals as a safety net: An evaluation of the midday meal scheme in India," Economic Development and Cultural Change, 62, $275-306$.

Singh, P. And J. Pundir (2002): "Women legislators in UP: Background, emergence and role," Economic and political Weekly, 923-928.

Singh, S. AND N. Gupta (2015): "Impact of mid day meal on enrollment,attendance and retention of primary school children," International Journal of Science and Research, 4, $1203-1205$.

Srinivasan, V., S. M. Gorelick, And L. Goulder (2010): "Sustainable urban water supply in south India: Desalination, efficiency improvement, or rainwater harvesting?" Water Resources Research, 46.

TAN, J. (2015): "Water privatization, ethnicity and rent-seeking: preliminary evidence from Malaysia," Journal of Southeast Asian Economies (JSEAE), 32, 297-318.

Thorat, S. And N. SAdana (2009): "Caste and ownership of private enterprises," Economic and Political Weekly, 13-16.

Topalova, P. (2010): "Factor immobility and regional impacts of trade liberalization: Evidence on poverty from India," American Economic Journal: Applied Economics, 2, 1-41.

UNICEF (2006): The state of the world's children 200\%: women and children: the double dividend of gender equality, vol. 7, UNICEF.

VAn Biezen, I. And P. KopeckÝ (2007): "The state and the parties: public funding, public regulation and rent-seeking in contemporary democracies," Party politics, 13, 235-254.

VArshney, A. (2007): "India's democratic challenge," Foreign Affair, 86, 93.

- (2012): "Two banks of the same river? Social order and entrepreneurialism in India," Anxieties of Democracy: Tocquevillean Reflections on India and the United States, 225-56. 
Vigneri, M. AND R. Holmes (2009): "When being more productive still doesn't pay: gender inequality and socio-economic constraints in Ghana's cocoa sector," in FAOIFADILO Workshop on Gaps, trends and current research in gender dimensions of agricultural and rural employment: differentiated pathways out of poverty, Rome March, Citeseer.

Wilkinson, S. I. (2006): "The politics of infrastructural spending in India," Department of Political Science, University of Chicago, mimeo, 31.

ZimMERMANN, L. (2012): "Labor market impacts of a large-scale public works program: evidence from the Indian employment guarantee scheme," Working Paper. 